Portland State University

PDXScholar

Winter 4-10-2014

\title{
Safety in Maize: Subsistence Agriculture in a Zapotec Migrant Town
}

Fiona Joy Gladstone

Portland State University

Follow this and additional works at: https://pdxscholar.library.pdx.edu/open_access_etds

Part of the Agricultural and Resource Economics Commons Let us know how access to this document benefits you.

\section{Recommended Citation}

Gladstone, Fiona Joy, "Safety in Maize: Subsistence Agriculture in a Zapotec Migrant Town" (2014). Dissertations and Theses. Paper 1669.

https://doi.org/10.15760/etd.1668

This Thesis is brought to you for free and open access. It has been accepted for inclusion in Dissertations and Theses by an authorized administrator of PDXScholar. Please contact us if we can make this document more accessible: pdxscholar@pdx.edu. 
Safety in Maize: Subsistence Agriculture in a Zapotec Migrant Town

by

Fiona Joy Gladstone

A thesis submitted in partial fulfillment of the requirements for the degree of

\author{
Master of Arts \\ in \\ Geography
}

Thesis Committee:

Martha Works, Chair

Teresa Bulman

Jack Corbett

Portland State University

2014 


\begin{abstract}
$\underline{\text { Abstract }}$
Subsistence maize production has long been a dominant economic activity of households in Santiago Apóstol, a Zapotec community in the Central Valley of Oaxaca, Mexico. A baseline study from 1973 documents a regionally pervasive form of household level agriculture whereby cultivators prioritize land for subsistence maize above commercial crops. Since then, much has transformed the face of rural Mexico, including migration to the United States. Migration accelerated beginning in the 1970 s as a response to government disinvestment in maize, but it may also be a new force of cultural and economic change impacting agriculture. The question arises, has migration modified longstanding subsistence agricultural practices centered on local varieties of rainfed maize? If not, what might explain the continuities and changes in agricultural practice observed? Ethnographic land use and maize consumption surveys among 19 migrantheaded households conducted in Santiago Apóstol in the summer and winter of 2012 indicate that mean production of maize remains equivalent to that documented in the late 1960s, suggesting that migration has not engendered a generalized shift to commercial crops. Potential explanations for the persistent use of rainfed, local maize among migrantheaded households are drawn from a mixed methods methodology involving triangulated analyses of household economic data, land tenure arrangements, perceptions of environmental change, participant observation, and archival research. Triangulated analyses allow speculation on linked human-environmental changes in the landscape that may have reinforced use of a traditional, rainfed grain crop.
\end{abstract}




\section{Acknowledgements}

This project depended on many people. For their attentive comments on drafts of the manuscript, I am extremely grateful to my advisor, Martha Works, and committee member Teresa Bulman. I would like to sincerely thank Jack Corbett for offering fieldwork guidance, personal connections, humor, and insights throughout the research process. Much appreciation is due to Iván Sandoval, Miriam Campos Cornelio, Claudio Martínez, Anne Whyte, CONAGUA, and the Welte Institute for guidance and support at various stages of the research, and to Concepción and Melissa Ruíz for their remarkable hospitality. This undertaking would not have been possible without funding secured by Teresa Bulman on behalf of the Portland State Geography Department and from the Tokyo Foundation through the Sasakawa Young Leaders Fellowship Fund. I would like to thank my non-academic mentors, Jennifer Morrissey and David Newhall, for keeping me on their immigration team through fieldwork trips and schedule changes. I am grateful to friends and family for their bottomless love and support, and especially to Robin Gladstone and Austin Brown.

The greatest measure of gratitude is reserved for friends and contacts in Santiago Apóstol, district of Ocotlán, Oaxaca, whose hospitality, knowledge, and curiosity made this inquiry not only possible but deeply fulfilling. Finally, I give thanks to the many people I have helped through the United States' immigration system over the past six years; their personal stories were the spur for my desire to research livelihoods in rural Mexico. 


\section{Contents}

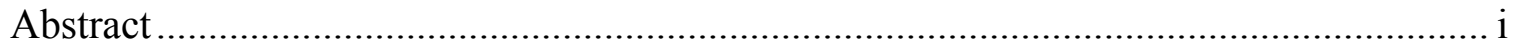

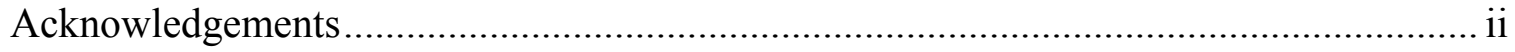

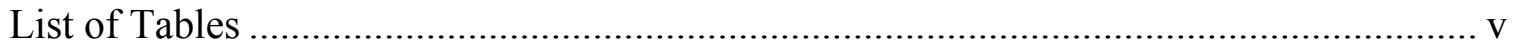

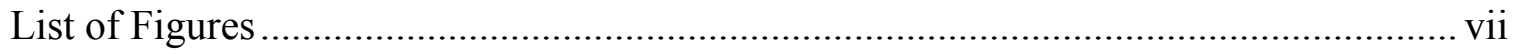

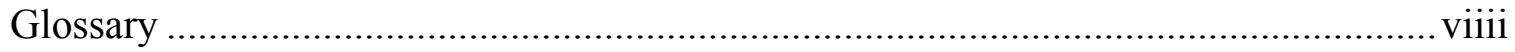

Introduction: Migrating Home to Maize .................................................................. 1

Political Economic Changes in Late $20^{\text {th }}$ Century Rural Mexico ................................. 7

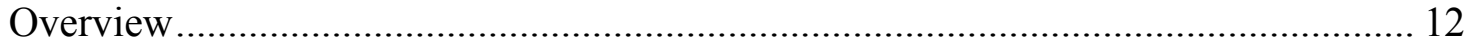

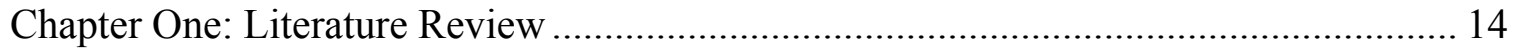

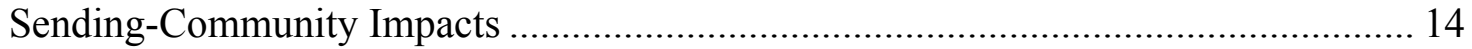

Subsistence and Commercial Agriculture in the Central Valley .............................. 17

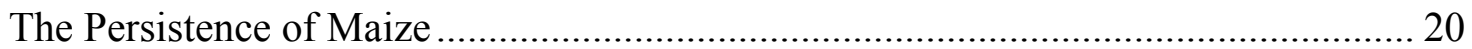

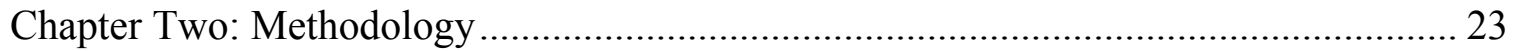

Migrant Household Land Use, Maize Production and Maize Uses............................. 24

Landscape Factors of Agricultural Change and Continuity....................................... 26

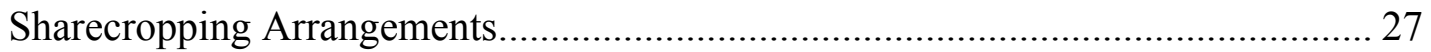

Perceptions of a Changing Local Climate ........................................................... 29

Supplemental Contextual Data ....................................................................... 30

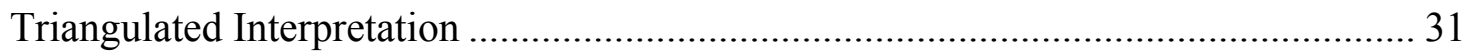

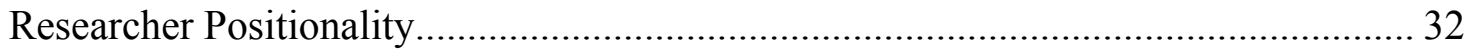

Chapter Three: Study Area and Historical Background ............................................... 38

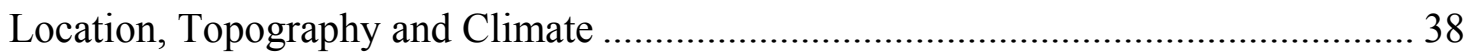

The Evolution of Santiago's Farming Society: From Closed, Corporate Community to

Transnational Town ...................................................................................... 42

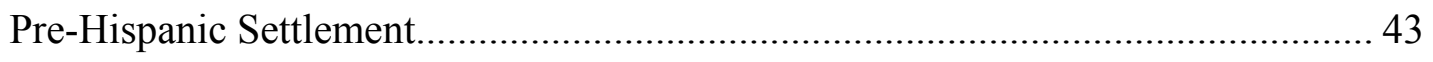

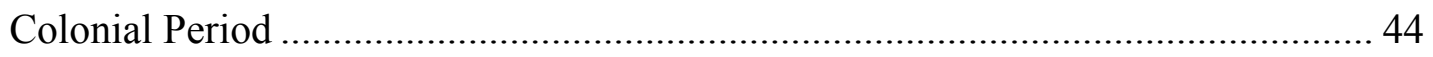

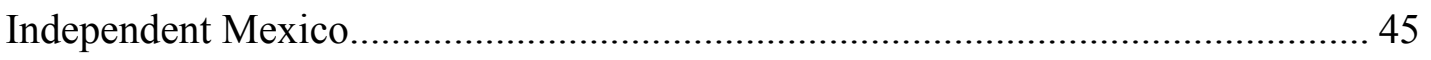

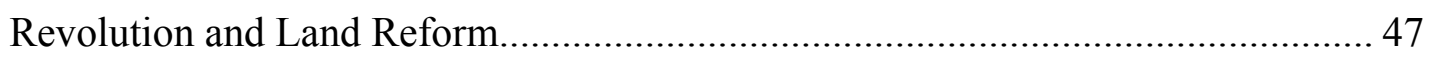

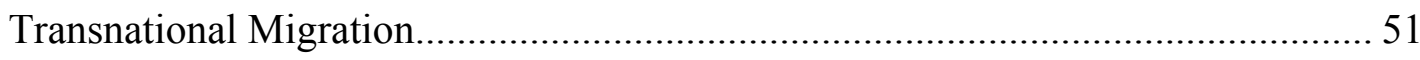

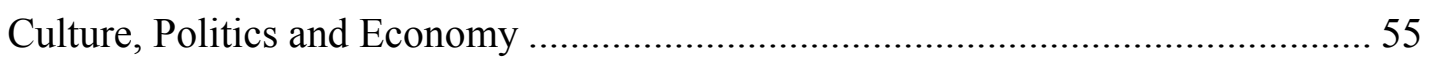


Chapter Four: Maize Production and Use in Migrant-Headed Households 64

Migrant Household Profiles 65

Household Land Use and Maize Production 67

Costs and Revenues of Maize vs. Cash Crops .................................................... 73

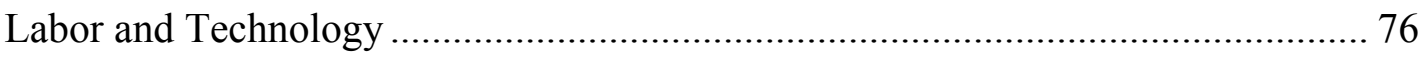

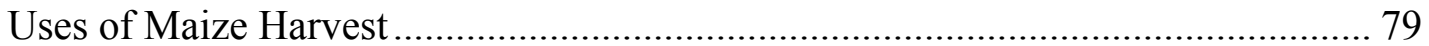

Chapter Five: Possible Drivers of Agricultural Change and Continuity ........................ 84

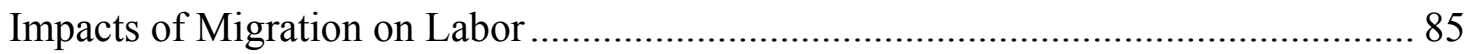

Impacts of Changing Water Resources on Agricultural Land and Migration .............. 88

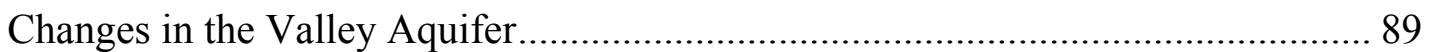

Inter-annual Precipitation, Maximum Temperature, and Evapotranspiration Records,

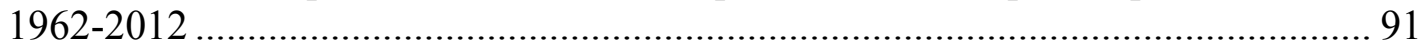

Residents' Perceptions of Environmental Change................................................ 96

Current Land-Tenure Arrangements ................................................................... 98

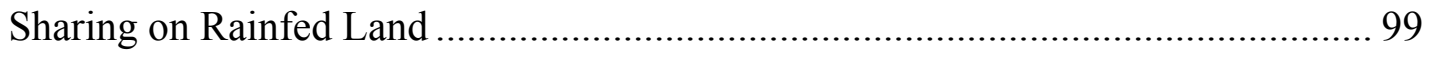

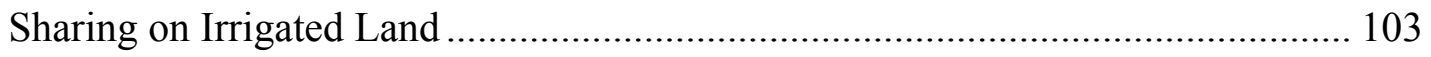

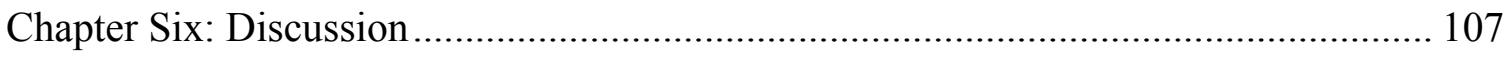

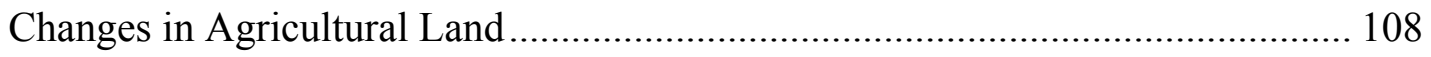

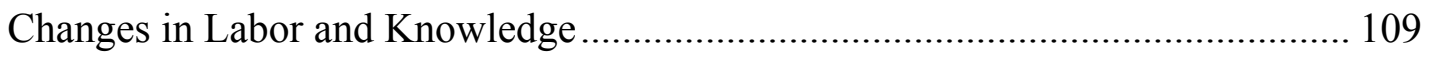

Changes in the Role of Capital ....................................................................... 110

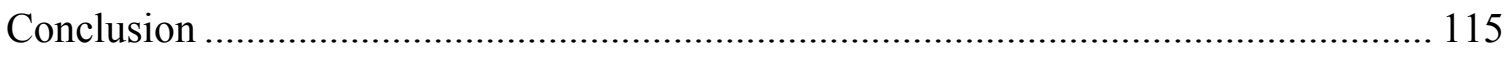

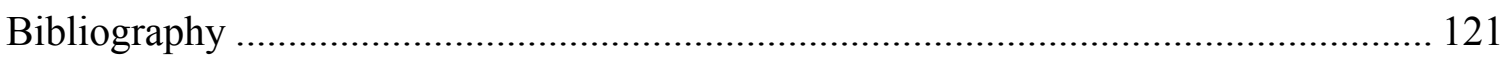

Appendix A: Human Subjects Approval Notice and Approval of Continuation............ 127

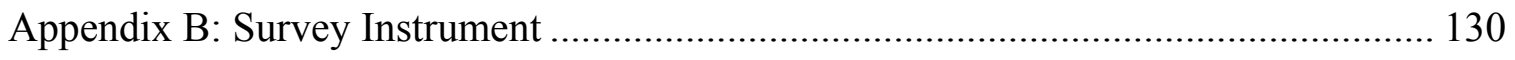

Appendix C: Land Tenure Arrangement Data......................................................... 134 


\section{List of Tables}

Table 1. Distribution of Oaxaca's Population by Size of Population Center.. .................. 5

Table 2. Historical Population and Dwelling Size in Santiago Apóstol........................... 52

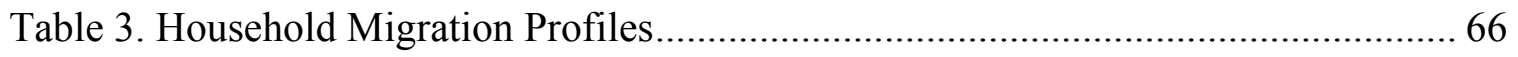

Table 4. Land Ownership and Use Among Migrant Households.................................. 69

Table 5. Maize Production Among Commercial and Subsistence-Oriented Migrant

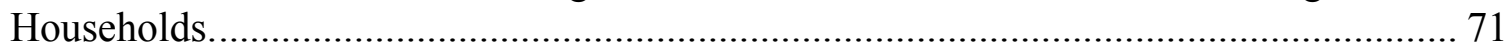

Table 6. Practices in Maize Production Among Migrant Households............................ 72

Table 7. Comparative Labor Requirements for Well-Irrigated Cash Crops and Dry-

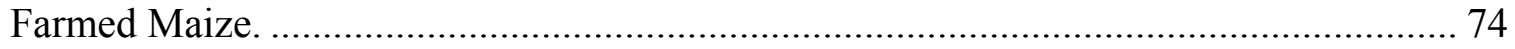

Table 8. Comparative Production Costs and Market Values ...................................... 75

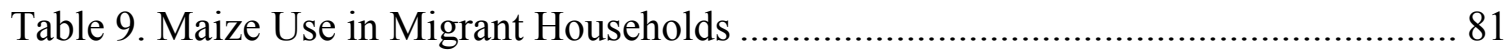

Table 10. Breakdown of Costs and Earnings in Daily Household Tortilla Sales............ 81

Table 11. Comparative Livelihoods: Tortillera, Field Laborer, Taxi Driver and

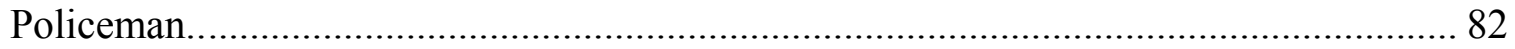

Table 12. Population Growth in the State Capital of Oaxaca de Juárez (Oaxaca City) and

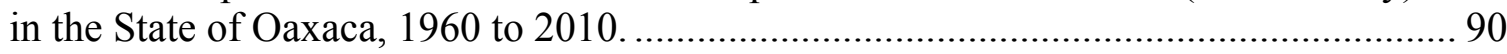




\section{$\underline{\text { List of Figures }}$}

Figure 1. Map of the Central Valley showing Santiago Apóstol approximately 30 kilometers south of Oaxaca City....

Figure 2. Mexican-Born Population in the United States, 1850-2011_........................... 9

Figure 3. Annual Immigration from Mexico to the United States, 1991-2010................ 11

Figure 4. Santiago Apóstol and neighboring communities......................................... 40

Figures 5a and b. a) Historical monthly temperature and precipitation averages in the Valley of Oaxaca. b) Monthly temperature and precipitation averages in the Valley of Oaxaca 1981-2010..

Figure 6. April to September Precipitation in Ocotlán de Morelos (1962-2000) and San Pablo Huixtepec (2003-2012) .............................................................................. 92

Figure 7. Historical mean daily maximum temperatures in Ocotlán de Morelos (19621984) and San Pablo Huixtepec (1985-2012)....

Figure 8. Average Daily Precipitation and Evaporation in San Pablo Huixtepec, 19842012 


\section{Glossary}

\begin{tabular}{|c|c|}
\hline \multirow{4}{*}{$\begin{array}{l}\text { a medias } \\
\text { atole } \\
\text { canícula } \\
\text { cargo }\end{array}$} & In sharecropping, to split the harvest $50-50$. \\
\hline & A hot breakfast drink of ground maize cooked in milk or water. \\
\hline & The mid-summer drought. \\
\hline & $\begin{array}{l}\text { Three-year position of community service as a functionary of local } \\
\text { government. }\end{array}$ \\
\hline cempasuchil & Aztec marigold flower. \\
\hline comal & A large, round ceramic griddle that rests above the cookfire. \\
\hline compadrazgo & An institution of fictive kinship involving affective bonds and reciprocity. \\
\hline costal & A large bag for storing maize. \\
\hline \multicolumn{2}{|c|}{$\begin{array}{l}\text { cresta de gallo Indian tursol, a flower with bright magenta blooms (literally, “cock's } \\
\text { crest"). }\end{array}$} \\
\hline criollo & Locally reproduced varieties of seed. \\
\hline crisantemo & Chrysanthemum flower. \\
\hline deez-uhl & The local language of Santiago, a dialect of Zapoteco. \\
\hline ejidatario & Member of an ejido. \\
\hline ejido & $\begin{array}{l}\text { A Mexican agrarian land use community in which the members, known as } \\
\text { ejidatarios, hold usufructory rights but not inalienable ownership. }\end{array}$ \\
\hline fiesta & Generally refers to a community-wide party or holiday. \\
\hline \multicolumn{2}{|c|}{$\begin{array}{l}\text { flor de penumbra A local cash-crop flower with pink, purple and blue blooms. } \\
\text { (English name unknown.) }\end{array}$} \\
\hline guelaguetza & \multirow[t]{2}{*}{ An institution of reciprocity involving exchange of goods or services. } \\
\hline hacienda & \\
\hline idioma & $\begin{array}{l}\text { A word that means language in Spanish and is used by Santiago's } \\
\text { residents to refer to their local Zapotec dialect, deez-uhl. }\end{array}$ \\
\hline & Seed-saved, local varieties of maize. \\
\hline \multicolumn{2}{|c|}{ nazareno/rojo red } \\
\hline \multicolumn{2}{|c|}{ amarillo yellow } \\
\hline \multicolumn{2}{|c|}{ blanco } \\
\hline \multicolumn{2}{|c|}{ negrito/belatub } \\
\hline \multicolumn{2}{|c|}{ pinto } \\
\hline Maseca & $\begin{array}{l}\text { A brand of industrially-produced corn flour manufactured by the Gruma } \\
\text { company. }\end{array}$ \\
\hline mazorca & Dried corn cobs. \\
\hline molino & Electric mill, used for grinding nixtamal and other foods. \\
\hline monte & Uncultivated land of shrubs, brush and trees. \\
\hline monte casino & Heath aster flower. \\
\hline mozo & Wage laborer. \\
\hline nixtamal & $\begin{array}{l}\text { Dry maize boiled in water with lime which, once ground, can be } \\
\text { elaborated into tortillas. }\end{array}$ \\
\hline nube & Baby's breath, a flower with small white blossoms that grow in a spray. \\
\hline & De-grained, dried corncobs. \\
\hline
\end{tabular}


pequeños propietarios Those holding titled private property.

perrito Delphinium flower.

petate A large woven mat that can be sewn into a vessel for storing dry maize.

por partidas In sharecropping, to indicate that the landowner receives $1 / 4$ of the harvest. refresco Soft drink; soda.

síndico Fiscal controller and judicial representative of the community.

tamale A maize dumpling wrapped in maize leaves or husk and steamed.

telesecundaria Television-based high school in rural Mexico.

tejate A refreshing cold drink made from ground maize and cocoa.

tequio One-year position of mandatory, unpaid community service.

tlayuda A large (dinner-plate sized), slightly crispy corn tortilla.

tortilla A thin, round flatbread prepared with soaked, ground maize and cooked on a comal.

tortillera A woman who prepares tortillas for sale.

totomozle Dried corn husks.

trueque A regional practice of direct trade.

usos y costumbres Traditional political system of closed, corporate indigenous communities based on a civil-religious hierarchy and separate from state and national politics.

yunta A pair of oxen for pulling a wooden plough.

zacate Dried maize leaves on their stalks.

zapoteco One of several indigenous languages prevalent in contemporary Oaxaca. Also refers to one who is of Zapotec ethnicity. 


\section{Introduction: Migrating Home to Maize}

Labor migration from Mexico to the United States over the second half of the $20^{\text {th }}$ century and into the $21^{\text {st }}$ has been a defining factor of the changing human geography of both countries (Marcelli and Cornelius 2001, Nelson 2008, Smith and Furuseth 2006, Verduzco and Unger 1998). As the demographics of towns and cities in the United States transform, so do communities in Mexico. But this change is not simply a demographic loss for Mexico. Many migrants do not expect, or even desire to spend their lives in the United States (Cohen 2004, Gabbarot and Clarke 2005, Stephen 2007).

In recent decades, migration scholars have introduced the term "transnational," rather than immigrant or emigrant, to describe migrants who parse their time, labor, and other forms of social presence across international boundaries (Schiller, et al.. 1995). Transnationalism is evident in the rural Mexican landscape, where new construction rises from migrant capital (Verduzco and Unger 1998, Fletcher 1999, Cohen and Rodriguez 2005). Transnationalism among rural Mexican migrants often involves maintenance of family obligations, investment of time and money to secure an inheritance, and participation in service institutions that form part of the cultural traditions of many rural Mexican communities (Cohen 2004, Gabbarot and Clarke 2005). For some, transnationalism includes timing visits home to coincide with local production cycles, including the annual planting and harvest of corn (Nagengast and Kearney 1990, Cohen 2004). The twofold necessity of pursuing work opportunities in the United States while 
maintaining social and economic ties in Mexico accounts for a great deal of inter-country travel, both under and around the law.

Significant factors have changed the dynamics of transnationalism among Mexican migrants to the United States in the past decade. Stringent U.S. border control since 2001 and the full-fledged wars among drug cartels and the Mexican army since 2006 have increased the costs and risks of crossing Mexico's northern border. Even more powerful than these factors was the Great Recession of 2008, during which the pull of jobs in the United States slackened considerably. For those able to maintain employment through the Great Recession, the dangers and expenses of border crossings have transformed intended short-term labor migrations into a semi-permanent relocation. But for others, the economic recession, dangers of border crossing, and expenses of travel have meant returning to Mexico permanently.

As recent statistics on the high level of return migration to Mexico suggest (Passel, et al.. 2012), labor migration to the United States offers few long-term guarantees, especially for those lacking immigration status. Travelling to work in the United States is essentially insecure: many of the low-wage jobs that rural Mexican migrants fill are temporary, and a lack of permanent lawful status tends to obstruct access to long-term resources. This insecurity only increases the relevance of maintaining ties to one's land, inheritance, and family in Mexico. For many of rural origin, agricultural fields, urban plots of land, new houses, and social institutions at home may provide a safety net for times of crisis or limited opportunity in the United States. 
This thesis takes the form of a historically-grounded ethnographic investigation into the farming practices of transnational migrants in the Central Valley of Oaxaca, Mexico, who have reengaged with agriculture upon return to their home community. A baseline geographical study conducted in this region in the late 1960s, before migration to the United States was widespread, showed that peasant farmers used their land and water resources to produce a target minimum amount of one ton of maize per year as the primary food security for their families (Kirkby 1973). The question arises, has international migration modified these longstanding subsistence farming practices? If not, what might explain the continuities and changes in agricultural practice observed among migrant-headed households?

The research site, Santiago Apóstol, is a small Zapotec farming and migrantsending community located in the southern branch of the Central Valley of Oaxaca, approximately 30 kilometers south of Oaxaca de Juárez, the state capital (Figure 1). The landscape and local economy of the community has long centered around the production and consumption of traditional rainfed maize. Its 18 square kilometers of agricultural land remain predominantly planted with maize (INEGI 2012a). Historically, diverse varieties of rainfed maize formed a staple crop for household subsistence, while most households also grew a variety of hand-irrigated cash crops, including flowers, vegetables and herbs. 


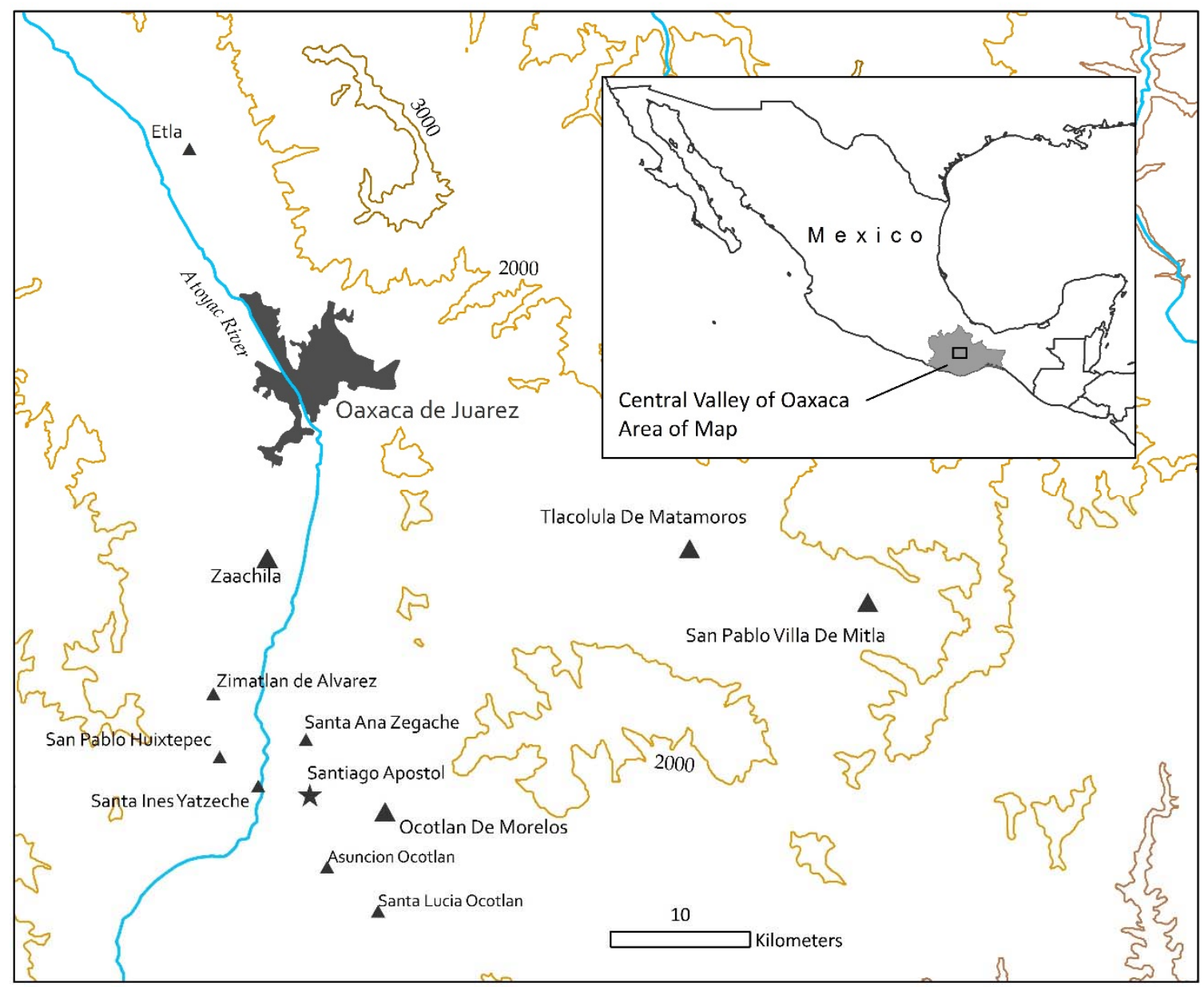

Figure 1. Map of the Central Valley showing Santiago Apóstol approximately 30 kilometers south of Oaxaca City.

However, as Mexico's rural communities have increasingly entered the fold of

Mexican politics and the globalized economy, both national and state governments have led peasant farmers towards Green Revolution ${ }^{1}$ agricultural technologies and marketdriven production (Hewitt de Alcántara 1976, Dilley 1973). The government has discouraged use of rainfed maize, a low-yield, low-profit crop, by removing price controls, liberalizing land tenure, providing support to Mexican farmers based on the size

\footnotetext{
${ }^{1}$ The Green Revolution refers to a modernization of agricultural production begun in the 1960s that dramatically increased agricultural yields of certain staple crops through improved seeds and technology packages involving chemical fertilizers, herbicides, pesticides and irrigation prescriptions (Wright 1990).
} 
of their farms, and advocating agricultural entrepreneurship (Barkin 2002, Fitting 2011). This has led to an increased reliance of small-holder farmers on off-farm sources of income (Fitting 2006, De Janvry and Sadoulet 2001).

International migration is one non-farm activity that rural Mexican households have pursued to adapt to an increasingly liberalized Mexican agricultural economy. Farming families in Santiago Apóstol, Oaxaca, are no exception. Today, some $35 \%$ of households in Santiago also count members who have migrated, most of them to the United States (Campos Cornelio 2012a). In this, Santiago's community reflects a broader phenomenon. Migration to the United States took hold among a significant number of Mexico's rural, indigenous communities in the past half-century. The southern state of Oaxaca accounts for just over three percent of Mexico's total population and five percent of Mexico's international migrant stream (INEGI 2010, 2012b). Nevertheless, more than half of the state's population still resides in rural communities of less than 2,500 residents (INEGI 2012c) (Table 1). Most of these communities have longstanding subsistence agricultural traditions.

Table 1. Distribution of Oaxaca's Population by Size of Population Center. Source: INEGI 2012c.

\begin{tabular}{|l|l|l|l|}
\hline Year & $\begin{array}{l}\text { Percentage of } \\
\text { population living in } \\
\text { localities with fewer } \\
\text { than 2500 residents }\end{array}$ & $\begin{array}{l}\text { Percentage of } \\
\text { population living in } \\
\text { localities with 2500 } \\
\text { to 14,999 residents }\end{array}$ & $\begin{array}{l}\text { Percentage of } \\
\text { population living in } \\
\text { localities with 15,000 } \\
\text { or more residents }\end{array}$ \\
\hline 2000 & 55.5 & 22.1 & 22.5 \\
\hline 2005 & 52.9 & 22.8 & 24.3 \\
\hline 2010 & 52.7 & 22.1 & 25.2 \\
\hline
\end{tabular}

Using a baseline historical study for comparison (Kirkby 1973), this thesis analyzes present-day practices of migrant households engaged in agriculture towards 
exploring, first, whether traditional agricultural orientations and practices have changed in migrant-headed households, and second, potential explanations for the changes and continuities observed.

The dynamic between migration and agricultural change in Latin America has been a topic of longstanding interest for geographers (Preston and Taveras 1980, Zimmerer 1991, Jokisch 2002, Gray 2009). Nevertheless, no studies have used historical sources to explore how household-level farming practices have changed with household head migration and return. Through comparison of present day cultivation practices with a baseline geographical analysis of peasant agriculture conducted before international migration took hold in the Central Valleys of Oaxaca, this study introduces a new level of contextual specificity to previously-explored questions regarding the impact of migration on rural sending-communities. Carried out in the context of increasing return migration to Mexico after the 2008 Great Recession, this research contributes timely perspectives on the role of return migrants in shaping their home communities' agricultural landscapes.

In the following section, I provide a short introduction to the historical political economy linking agricultural commodity market liberalization and Mexican migration to the United States. An explanation of the broader structural processes in which Santiago's farmers have become migrants is important context for exploring the primary productive activity of transnationals in Santiago Apóstol in the wake of the Great Recession. 


\section{Political Economic Changes in Late $20^{\text {th }}$ Century Rural Mexico}

A summary of changes in government economic policies and migration trends from Mexico to the United States over the late $20^{\text {th }}$ century is key context for exploring the broader processes of U.S.-Mexican migration underway in the study site of Santiago Apóstol. One cannot discuss the political economy of migration and rural community change in late $20^{\text {th }}$ century and early $21^{\text {st }}$ century Mexico without continuous reference to the United States. The countries' economies have long been entwined, but have been increasingly interdependent in the period concurrent with record-high levels of migration from Mexico to the United States. In this section, I discuss the history of U.S. and Mexican economic policies in the second half of the $20^{\text {th }}$ century and into the $21^{\text {st }}$ that have transformed Mexican agriculture and spurred migration from Mexico's rural communities to the United States.

Mexican migrants to the United States have historically travelled from rural municipalities where agriculture forms the basis for economic activity. Before the turn of the millennium, $60 \%$ of Mexican migrants to the United States hailed from locales with fewer than 20,000 inhabitants and less than $2 \%$ from municipalities with more than 50,000 inhabitants (Verduzco and Unger 1998, 398). In 1970, 41 percent of Mexico's economically active population worked in the agricultural sector and in the same year 47.7 percent of the population lived in locales with fewer than 2,500 inhabitants (Alba and Potter 1986, 53, 56). A decade ago Mexico's population was approximately one-third rural (Barkin 2002). Today, approximately one-quarter (23.2\%) live in locales with a population of less than 2,500 inhabitants (INEGI 2010). Migration to the United States 
from urban parts of Mexico has become more significant only in the past two decades (Riosmena and Massey 2012).

For most of the $20^{\text {th }}$ century, small-population municipalities in Mexico engaged in farming as a primary activity even as some community members left to pursue wage work opportunities outside their communities either seasonally or semi-permanently. Responding to the changing constraints around their traditional, agricultural livelihoods as well as the variable demands and opportunities for wage labor outside their home communities, many took jobs in industrial agriculture in northern Mexico, or in factories, construction sites and domestic service in Mexico City (Rees 2006). The United States' Bracero program recruited agricultural laborers in the 1940s and 1950s to fill a U.S. wartime labor shortage. However, it was only after 1970 that migration to the United States began increasing exponentially (Figure 2). By the 1980s, working in the United States was a commonplace livelihood in many of Mexico's rural, agricultural communities. International labor migrants from Mexico's rural sector were historically men, but women soon followed husbands or brothers and began responding to U.S. employers' recruitment efforts. They have increasingly participated in international labor markets in addition to their longstanding participation in rural-urban migrations within Mexico. 


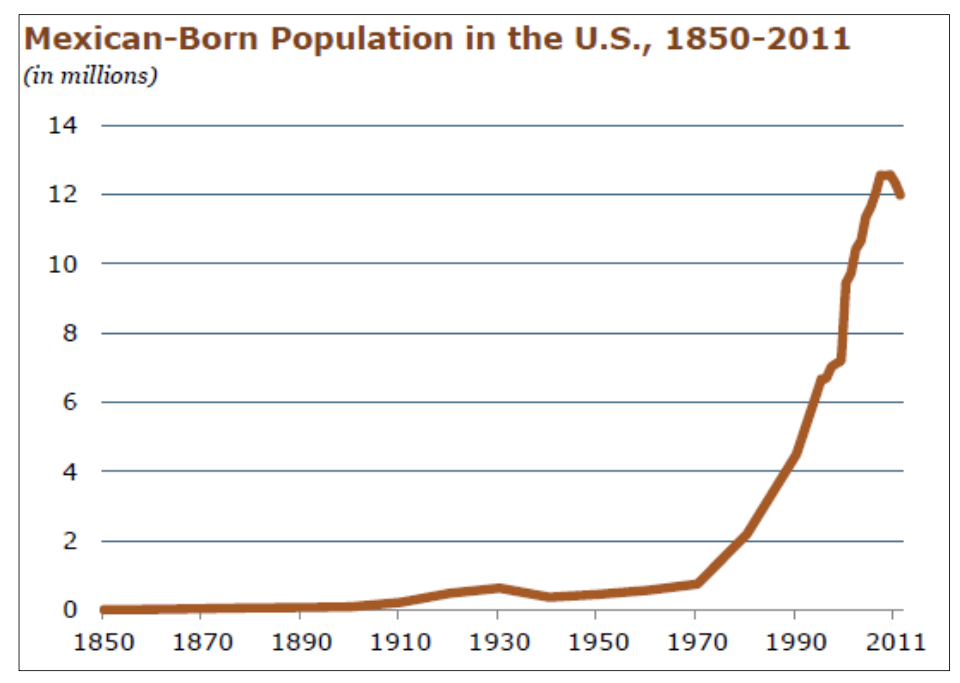

Figure 2. Mexican-Born Population in the United States, 1850-2011. Source: Passel et al. 2012.

Bi-national economic policies impelled this late $20^{\text {th }}$ century upsurge in MexicoU.S. migration. Scholarship has tied the sharp increase in migration from the 1970 s onward to recession-era economic restructuring in the United States (Rees 2006). A theory of "migration-systems" held forth by Marcelli and Cornelius (2001) explains this link between migration and political economy:

[F]irms seeking to lower labor costs and increase investment returns can be expected to petition the government to implement domestic and foreign policies favorable to business interests and likely to create or reinforce international migration flows.... [T] he demand for immigrant labor has become structurally embedded in the political economies of receiving countries (108).

The demand for low-wage agricultural laborers in California, and for other cheap labor in the United States, formed a strong pull on Mexico’s rural migrants.

Beginning in the 1980s, bi-national economic policies facilitating commodity and capital flows between Mexico and the United States pushed Mexico's farmers to migrate abroad by undermining their agricultural livelihoods (Eakin 2006, Otero 2011, Fitting 2011). The North American Free Trade Agreement, which Mexico signed with the 
United States and Canada in 1994, was the final act in a series of liberalizing reforms designed to address a domestic debt crisis that erupted in Mexico in 1982. Following the Mexican debt crisis, domestic agricultural policies overtly pressured farmers to switch to more profitable, export-oriented crops or to leave their farms altogether (Barkin 2002, Preibisch, et al. 2002). Important subsidies and price-controls for smaller commercial farmers were removed. As Mexico's then-Under Secretary of Agricultural Planning stated in San Diego in 1991, "It is the policy of my government to remove half of the population from rural Mexico during the next five years" (Barkin 2002, 81).

Maize imports from the United States and levels of migration to the United States both rose following the North American Free Trade Agreement of 1994 (Preibisch, et al. 2002). Imports accounted for $2 \%$ of Mexico's maize consumption in 1993, before the NAFTA was signed, and 25\% of its maize consumption in 1999 (ibid). These trends have continued into the $21^{\text {st }}$ century. Mexico is the second biggest importer of U.S. maize on the world market, accounting for 7.9 million metric tons of maize shipped to Mexico in 2010 (U.S. Census Bureau 2012, 548). It trails only Nigeria and Japan in U.S. wheat imports, China in U.S. soybean imports, and is the number one foreign market for U.S. poultry (ibid). The United States has been the world's leading exporter of both maize and wheat from 2000 to 2010; Mexico the world's second largest importer of maize in that period (ibid).

Migratory activity increased as Mexico's neoliberal reforms undermined its rural sector's traditional livelihood of growing staple grains and has only recently diminished and reversed. The late 1990s to mid-2000s showed ever-increasing numbers of Mexican 
nationals entering the United States, with peak numbers in 2000 and 2004. However, migrations slowed after 2004 (Figure 3). A PEW Hispanic Center report states that Mexican migration to the U.S. had dropped to net zero in 2012 as migrants returned to Mexico (Passel, et al. 2012). The rising costs of undocumented border-crossing, its association with violent criminal organizations, stringent immigration enforcement, and the recent global recession have contributed to a substantial number of migrants returning to Mexico. These circumstances have also deterred both former migrants and first-time migrants from undertaking the journey north (ibid).

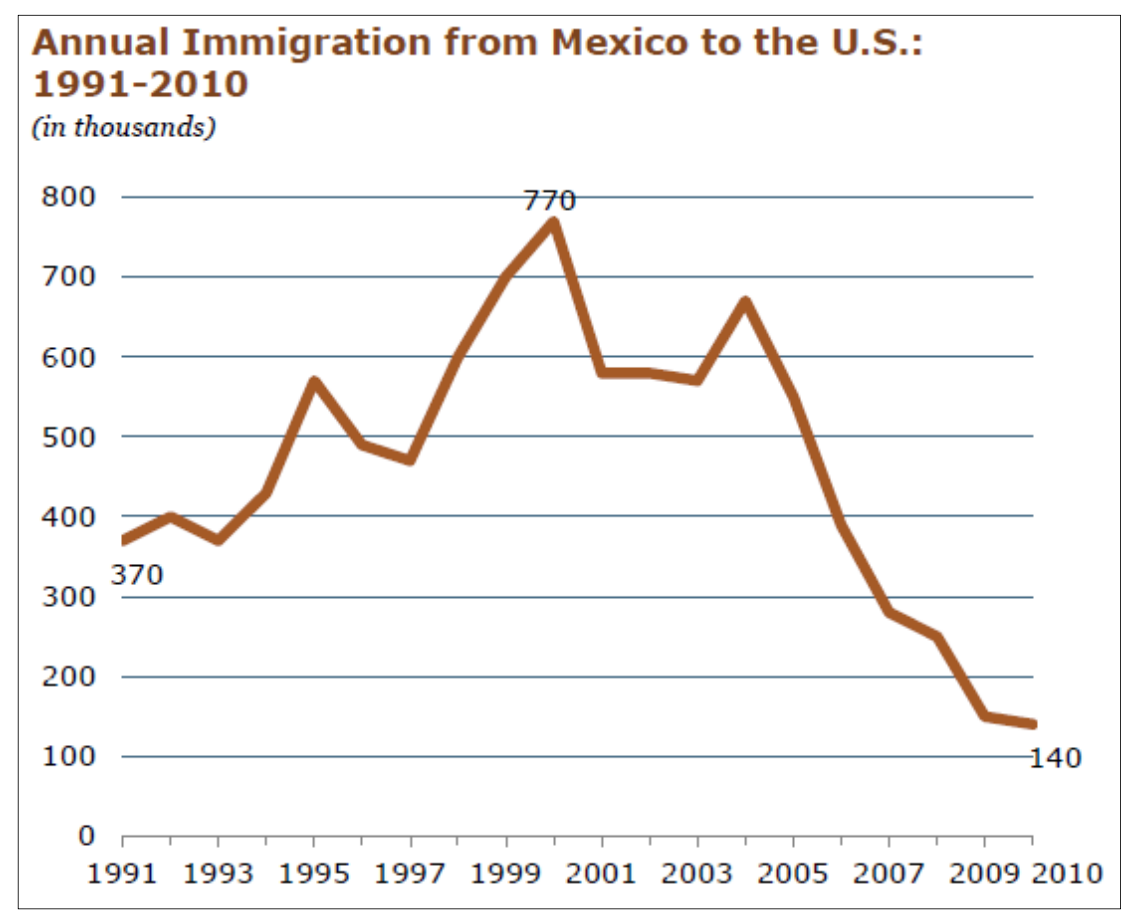

Figure 3. Annual Immigration from Mexico to the United States, 1991-2010. Source: Passel et al. 2012.

Recent statistics demonstrate the contingency of transnational labor migration from Mexico upon both economic opportunity in the United States and safe passage. The currently high levels of return migration invite scrutiny of the transformations that have 
taken place in Mexico's migrant-sending communities in recent decades. Because a majority of Mexico's transnational laborers were born in smaller, rural communities with longstanding agricultural traditions and institutions, production processes in these areas merit particular attention at this time (Verduzco and Unger 1998, Massey and Riosmena 2012).

\section{Overview}

Six chapters structure this investigation into present-day maize agricultural practices among migrant and return migrant heads-of-household in Santiago Apóstol, Oaxaca. In the first chapter, I review three main bodies of geographic and other social science literature relevant to framing the contributions of this study. In Chapter Two, I outline the methods of data collection and analysis. In Chapter Three, I introduce the reader to the study area's physical geography, its history, its late $20^{\text {th }}$ century migration patterns, and the evolution of its cultural, political and economic practices.

In Chapter Four, I analyze primary ethnographic survey data to determine whether migration has modified longstanding maize agricultural practices at the household level, scrutinizing land use, production and consumption. Although some changes in practices have taken place, the data shows that a majority of households surveyed maintain a minimum level of maize production that is comparable to that observed before migration was commonplace (Kirkby 1973). The data indicates that migration has not modified the longstanding tendency of peasant agriculturalists in this region to focus their land and labor resources on production of a minimum amount of maize. 
To speculate on potential contextual factors influencing the agricultural practices and orientations observed in migrant-headed households, I present, analyze, and interpret data regarding land tenure contracts, water resources, and perceptions of local climate change in Chapter Five. Both changes in land and labor relations and biophysical data indicate that two landscape-level processes - migration and changes in groundwater availability — may be forces of change influencing continuity in agricultural practices among Santiago's migrant farmers. Finally, in Chapter Six, I synthesize results from these triangulated analyses to explore how the continuity in household practices observed may relate to community-wide changes in land, labor, knowledge and capital required for different agricultural orientations. I conclude with a summary of the findings and questions for future research.

As a traditional community that has experienced accelerated cultural, economic and environmental changes over the past half-century, Santiago Apóstol offers a case study for examining how agricultural traditions and practices in rural Mexico have evolved with migration, a key factor in late $20^{\text {th }}$ century and early $21^{\text {st }}$ century change. Through comparison of the agricultural practices of migrants and their families today with a baseline study from 50 years ago, and analysis of contextual factors that might explain continuity and/or changes in these practices, this study seeks to open a new and timely window into the dynamics between migration and agricultural change. 


\section{Chapter One: Literature Review}

This study contributes to three general bodies of literature on contemporary (late $20^{\text {th }}$ - early $21^{\text {st }}$ century) agricultural change in Latin America, addressing first, the impacts of migration on agriculture; second, the differences between subsistence and commercial agricultural orientations in the study area region and their significance; and third, the prevalence of maize in various parts of modern rural Mexico despite broader political-economic forces that have undermined maize-based livelihoods.

\section{Sending-Community Impacts}

Research focused on agricultural sending-community dynamics stemming from migration has offered important geographical insights regarding how migration may or may not transform local agriculture. However, no study has yet benefited from a baseline analysis of agricultural goals and rationales for producing different crops in a region before migration was commonplace. The historical study used as a baseline here, The Use of Land and Water Resources in the Past and Present Valley of Oaxaca (Kirkby 1973) enables comparison of contemporary household-level land use and maize production with that of household-level agriculture in the 1960s, to determine what has and has not changed in the household's resources and rationales in the context of migration.

The theoretical premise of labor loss and concurrent capital influx (in the form of remittances) has generated several studies of sending-community social change and change in landscape composition following migration, drawing primarily on comparisons 
between migrant and non-migrant actors and on inter-community case study comparisons. These have yielded valuable insights. For example, in Ecuador, a study found that farmland can become abandoned or become "cultivated real estate" in accordance with capital influx associated with migrants, although agricultural practices themselves were not significantly different between migrant and non-migrant households (Jokisch 2002). Farming can become dominated by urban landowner versus rural sharecropper relationships as migrants leave agriculture (Weisz 1978). Migration out of agriculture entirely can result in freeing up land for more equitable access (Preston and Taveras 1980) and/or increased land-tenure contracts that are not necessarily exploitative (Colin 1998). With respect socio-ecological systems, crop biodiversity has been found to decrease with increased participation in off-farm labor (Zimmerer 1991, Pita Duque 2000, Gray 2009). On the other hand, diverse, subsistence-oriented cultivation is often upheld by women as the de-facto guardians of food security and agrobiodiversity (Preibisch et al. 2002, Momsen 2004, Chambers and Momsen 2007).

Together, these studies present a diverse array of conclusions regarding how migration impacts sending-community agriculture, commonly through inter-community and migrant vs. non-migrant household comparisons. However, no study has yet benefitted from a comprehensive analysis of rationales underlying forms of agricultural production in a single cultural landscape from a period preceding increased migration activity. The existence of such a historical document for the region under analysis in this study thus provides the basis for detailed, comparative analysis of changes in migrant household agricultural practices and in the landscape. 
While research on the impacts of migration in the Valley of Oaxaca has brought excellent descriptions of the cultural dimensions of this phenomenon (Cohen 2004), the traditional agricultural economy — bound by questions of space, place and landscapehas not come under rigorous scrutiny. One study on migration in Oaxaca examined the direct impact of migrants' remittances to assess whether migration enables or constrains local economic development, using an extensive household-level survey to compare productive investments with everyday expenses (Cohen and Rodriguez 2005). However, the dichotomy between productive and everyday expenses offers limited insight into the operation of the traditional, situated provisioning processes. In a traditional agricultural society, everyday expenses may include regular monetary commitments to field labor, animals, seed, and other inputs for upholding local agricultural institutions that do not follow an individual logic of accumulation and "productive" investment. The structural differences between the local agricultural society's daily provisioning economy and that of the modern, industrial capitalist society appear muddled in this dichotomy between "everyday" and "productive" remittance outcomes. Accordingly, research that begins from an in-depth historical analysis of sending community social and economic structure is better poised to address the impacts of migration, which inevitably arises in analyses of rural Mexico (e.g., Colin 1997, 2005). This thesis makes use of a rigorous geographical analysis of household agricultural practices in the region from before international migration was widespread, enabling deeper insights into the possible impact of migration on agricultural practices in the Valley of Oaxaca. 


\section{Subsistence and Commercial Agriculture in the Central Valley}

In updating research on the practices of farmers in the Central Valley of Oaxaca throughout the second half of the $20^{\text {th }}$ century, this study renews and reframes historical, theoretical debates about subsistence versus market-destined provisioning in this region. Previous research on maize agriculture in the Central Valley region has introduced an $a$ priori difference between an economic system that centers on the accumulation of profit through an entirely commercialized exchange of resources among actors who seek to maximize personal gains, and one centered on subsistence agriculture, select market engagements, and economic institutions of reciprocity and redistribution that secure basic social reproduction (Kirkby 1973, Dilley 1993). While the distinction between these models appears to have blurred with the cultural and economic effects of globalization, identifying the economic systems under which individual agricultural choices have historically been made in the Central Valley of Oaxaca provides a useful point of departure for exploring the crop production decisions of migrant households today.

In a baseline study of Central Valley agriculture, Kirkby (1973) focused on identifying how independent cultivators, operating in service of their households, managed land and water resources for combined subsistence and cash crop production in the late 1960s. According to her analysis of land use decisions and rationales underlying productive activity, peasant producers throughout the Central Valley of Oaxaca followed a "minimaxing" provisioning strategy, minimizing risk as a constraint for maximizing gains. Cultivators minimized risk by maintaining production of at least one ton of maize 
as subsistence grain for the household's use. Then, they maximized gains by dedicating remaining land and water resources to riskier commercial crops (Kirkby 1973).

The economic principles underlying agricultural choices, however, could change over time. Kirkby (1973) perceived minimum levels of subsistence production diminishing over the course of her fieldwork. Her analysis of pot-irrigated cash crops first indicated that, "in cash crop production, as well as subsistence corn production, peasant agriculturalists are aiming for satisfaction rather than for maximum profits" (Kirkby 1973, 116-117). However, she concluded that the "increasing commercialism of some irrigators indicates that these attitudes are undergoing change at the present time" (ibid, 117). This reorientation towards commercial activity could be seen in the land use area Kirkby sampled near Santiago Apóstol. In it, the area planted with subsistence maize decreased over four years of fieldwork from 1967-1970 (Kirkby 1973, 97).

Kirkby also articulated how natural resource availability, particularly the availability of water in an arid region, would structure land use decisions in agriculture. She argued that access to water for irrigation had the potential to limit commercial crop production in future years:

Depth to the water table will ultimately act as a limit on the practice of pot irrigation since (1) if the water is close to the surface irrigation will be unnecessary, and (2) at the other end of the scale the water table will eventually become so deep that pot irrigation is not practicable. (Kirkby 1973, 105-6).

Considering the environmental constraints on irrigation along with the increased commercial orientation of irrigators, Kirkby foresaw a water supply crisis that has since developed in Oaxaca as a result of groundwater pumping for cash crops and the growth of urban centers. Kirkby thus addressed the underlying geographical conditions for 
different economic orientations in agriculture, including the point at which the water table acts as a limit on commercial crop expansion.

Twenty years later, Dilley (1993) compared the aforementioned economic orientations again, more forcefully articulating the implications of modern commercial capitalism for nature-society relations in the Central Valley. Dilley considered the transformative impacts of globalization and climate change on maize agriculture in the Central Valley using a theoretical framework that placed climate change impacts in socio-historical context. With attention to the combined impact of globalization and climate change, Dilley offered an early example of "double exposure," (O’Brien and Leichenko 2000), a term for the compounded adverse impacts of climate change and globalization on the world's most vulnerable populations.

Dilley (1993) argued there are two modes of production in Oaxaca, a traditional agricultural sector where "[c]ommunity institutions govern the distribution of land, water and wealth" and a modern agricultural sector in which these assets are governed by the market, which has grown with urbanization (1993, iv). He further asserted the relevance of analyzing the "increasing influence of the larger capitalist economy over that of the Valley" in modeling the impacts of climate change on maize farmers in Oaxaca (ibid). After rigorously demonstrating the primary influence of rainfall on maize yields in the Valley and the relevance of synoptic circulation patterns governing rainfall, Dilley turned to addressing the potential impacts of climate change under two hypothetical scenarios: increased precipitation versus increased drought in the Central Valley. Reflecting upon the "increasing influence of the larger capitalist economy" (1993, iv), Dilley concluded 
that either moisture-dependent cash cropping would expand with increased monsoon rains or drought would provoke rural-urban migration $(1993, \mathrm{v})$.

Kirkby (1973) and Dilley (1993) thus linked human-environment relations to the economic system of a society and the economic principles governing its individual actors. Each highlighted the environmental ramifications of the capitalist development model for the traditional agricultural economy of the Valley, and its implications for entwined environmental and social outcomes. Both suggested that a model of capitalist development whereby the population moves towards a more market-based agricultural economy (Kirkby 1973), or abandons agriculture for wage labor (Dilley 1993), was already underway. However, Dilley's study left open the question of how rural-urban migration (domestic or international), which he predicted in the context of a "dry" climate scenario, might involve a continued engagement with the agricultural landscape. Likewise, Kirkby's study was conducted before significant migration activity had ensued in the region and offers no speculation on how migration might impact the use of land and water resources for subsistence agriculture in the Valley. This thesis seeks to close both of these gaps.

\section{The Persistence of Maize}

As a final point of engagement with existing scholarship, the present study contributes to a growing body of ethnographic research on the endurance of maize agriculture in diverse settings throughout rural Mexico, with new attention to regional historical context and to return migration. By focusing on evolving processes of production and consumption among migrant and return migrant households, this project 
contributes to a small but important body of literature that has arisen from ethnographic research in rural Mexico in the past ten years. This literature indicates that, contrary to all expectations based on government policies that have attempted to undermine Mexico's domestic maize production, maize agriculture remains vital and widespread in many parts of rural Mexico.

Recent ethnographic research regarding the changing rationales for farming under Mexico's liberalized economy demonstrates the endurance of corn agriculture in distinct regional contexts. Fitting $(2006,2011)$ found increasing monetization of agricultural activity in one Mexican migrant-sending community in Puebla, in which households were less oriented towards subsistence traditions and increasingly oriented towards marketoriented activities, be these off-farm wage labor or new crops that could fetch a higher price in urban markets. However, one market orientation reflected the security inherent in maize as a subsistence crop. In the Tehuacán Valley, farmers grew maize for elote, or "corn-on-the-cob" to be sold at market in Mexico City. When the price of elote was unfavorable, the corn could be dried and stored for subsistence production of tortillas and as animal fodder. Although a cultural rejection of subsistence traditions that could not produce monetary capital appeared among the younger generations, especially in the context of local manufacturing plants offering an alternative livelihood, maize remained a dominant crop in the community.

In another case of enduring maize agriculture in an indigenous community where men had mostly turned to off-farm employment, researchers found the community's women "defending food security in a free-market economy" (Preibisch et al.. 2002). That 
study of household provisioning practices in the rural community of Emilio Portes Gil, state of Mexico, showed women making decisions, carrying out most of the field labor in maize cultivation, and controlling the harvest to ensure household food security (ibid). In other cases, rural Mexican communities were found to share "a common goal: how to guarantee their subsistence in spite of declining producer prices, rising costs, insufficient services, and increasingly, climatic risks" (Eakin 2006, 53). Risk-averse strategies abounded, especially the use of traditional maize varieties in combination with as many livelihood diversification efforts as possible, including migration (Eakin 2005, 2006). The findings of these contemporary ethnographic studies in rural Mexico echo Barkin (2002), who argued that maize agriculture constitutes a particular form of cultural articulation among Mexico’s “modern peasantry” (Barkin 2002). An alternative perspective might frame it as a survival strategy in the absence of an adequate alternative social safety net. Through attention to the historical analyses of agriculture and climate in Oaxaca’s Central Valley (Kirkby 1973, Dilley 1993) and the livelihood orientations of migrants returning to rural Mexico, this thesis brings new empirical data and perspectives to the growing discussion of widespread, yet locally variable, uses of maize in contemporary rural Mexico. 


\section{Chapter Two: Methodology}

The methodology used in this study was selected to address two central goals: first, to discover whether household-level migration has modified longstanding agricultural practices centered on producing a minimum amount of subsistence maize; and second, to contextualize and interpret present-day agricultural practices in migrant households through an exploration of potential drivers of change in the landscape. I approached the questions of this project through a methodology of concurrent, triangulated mixed methods that enables the researcher to seek "convergence, corroboration, and correspondence" among independent datasets subjected to quantitative and qualitative analysis (Creswell 2003, 62). Methods of data collection to address the first goal involved an ethnographic survey of migrant household agricultural practices that encompassed land use surveying, participant observation and unstructured interviews. Methods of data collection to address the second goal included several concurrent mixed methods, including: 1) surveys of land tenure arrangements and perceptions of climate change throughout the community; 2) gathering and analyzing archival climate and hydrological data from government entities; 3) archival research at the National Agrarian Registry office, and 4) participant observation and interviews. Data collection was carried out over two field seasons amounting to a cumulative seven and a half weeks in June, July and December of 2012. Analysis included processing survey data into descriptive statistical summaries and visualizations, then interpreting these results in triangulation with the qualitative information gathered in participant 
observation and interviews. In this chapter I summarize these methods. I conclude the chapter with a discussion of researcher positionality, reflexivity and conduct, and of how the chosen methodology best fit the central goals and practical constraints of the research.

\section{Migrant Household Land Use, Maize Production and Maize Uses}

To determine whether household migration had impacted longstanding household-level agricultural practices centered on minimum production of subsistence maize, I conducted an ethnographic survey of 19 migrant households engaged in agriculture in the year 2012. I defined "migrant households" as those for which the household head is either a returned international migrant or is currently away in the United States. For each migrant household, I gathered data regarding the number of household members, their ages and migration histories, their current land holdings, the proportions of land allocated to different crops, the quantity of maize harvested, and the expected uses of maize produced. I then calculated the proportion of cultivated land under maize in the current year (planted in the 2012 growing season), and the total quantity of maize produced (harvest season of 2012). I summarized the results with descriptive statistics that would allow me to compare the data on current practices with maize production practices observed in the 1960s (Kirkby 1973).

For the initial field visit of five weeks in June-July of 2012, I identified migrant households engaged in agriculture, and carried out household land use surveys, participant observation, and unstructured interviews in each household to determine current land use, maize production (if any) and maize use. I helped my new contacts plant, fertilize and weed their maize fields, so learning the techniques and timing of these 
actions as well as the costs and labors involved. I measured landholdings and drew field maps, noting current cropping choices. I recorded whether each plot of household land was owned, borrowed, or sharecropped, and if sharecropped, what portion of the harvest was retained by the sharecropper. I noted the range of labor sources (singlehanded, with hired laborers, family labor, or labor exchange) and technologies (fertilizer type, plough technology chosen), used in farming activities.

I also arranged unstructured interviews with the household heads in their homes. Interviews generally addressed questions to both husband and wife, but sometimes just one or the other. Interviews covered household migration history, current maize production and consumption, other productive activity and income sources, and other household members' ages and livelihoods. Interviews often took place amidst participant observation of the processes of production and consumption, such as de-graining corn cobs or preparing tortillas. I noted where and when the household head and any other migrants in the family had travelled, for how long, and for what jobs. I noted comments regarding the changing costs and challenges associated with migration. In some cases I was able to ask how much capital had been remitted and/or saved from work in the United States. I also asked whether investments in land, home construction or welldigging had been made possible by migration earnings saved. I noted ownership of well pumps, tractors and other farming tools.

To learn how the maize harvest was used, I asked how many months the maize harvest had lasted in the home this past year. I recorded maize storage methods (i.e. in 50-kilogram grain bags (costales), woven mats stitched into cylinders (petates), in a heap 
of unshucked mazorca (grain-on cobs), etc.), the amount stored, and how much maize had been produced at harvest.

In addition, I noted weekly tortilla preparation both for household consumption and for sale, animal holdings and the amount of corn allocated to animals. I noted the amount of maize required for tortilla production, and the quantities, costs and revenues from tortilla sales. Finally, I noted other economic activities that contributed to household income and/or provisioning.

I continued this surveying activity during the second field visit of 2.5 weeks in December of 2012. I recorded all field notes with a voice recorder or notebooks and subsequently transcribed these into electronic documents and/or printed survey forms. After both fieldwork trips, I had documented agricultural activities, U.S. migration histories, maize production and household maize uses in nineteen migrant households. Then, I analyzed data collected using descriptive statistics to assess whether household head migration had modified longstanding agricultural practices documented by Kirkby (1973).

\section{Landscape Factors of Agricultural Change and Continuity}

To be able to speculate on why migrant households had maintained subsistence maize traditions, or why these practices had changed, I gathered additional data on community-level and broader-scale processes affecting agriculture in the landscape, focusing on factors of change in the past 50 years. Methods of data collection included surveying land tenure arrangements, surveying local residents' perceptions of local climatic change, archival research, supplementary interviews, and participant 
observation. I processed the surveys and archival data collected as descriptive statistical summaries and visualizations. Then, I interpreted them in triangulation with each other and with data from my field notes (participant observation) to speculate on potential explanations for the land use practice continuities and changes documented in the primary survey.

\section{Sharecropping Arrangements}

Several of the migrant households who participated in the primary survey were cultivating on land that was not their own or had let their owned land out to sharecroppers. An interesting portrait of diverse sharecropping contracts had emerged from interviews and participant observation with a broad base of contacts I had developed consisting of landowners and sharecroppers throughout the community. I devised a survey of current sharecropping arrangements to improve my understanding of the range and nature of land tenure arrangements in the community and how they have evolved in ways that may contextualize migrant households' agricultural practices. All arrangements were verbal agreements between landowner and sharecropper, and accordingly, I learned their details through conversations with landowners and sharecroppers. The purpose of this survey was not to comprehensively document the distribution of sharecropping arrangements in the community, but rather to gather information on the variety of contracting types to understand how these might influence agricultural practices and cropping decisions. To gain historical perspective on sharecropping institutions in the landscape, I drew on secondary sources, oral history, and National Agrarian Registry archives. 
For the survey, I gathered details for 23 different sharecropping contracts. Data solicited on sharecropping included: the name of the arrangement (a medias or por partidas), the nature of the sharecropper-landowner relationship (whether kinship or friendship based, or a purely economic arrangement), what was being farmed, whether on rainfed or irrigated land, and whether the landowner was an absentee (having migrated to the United States or Mexico City). I also recorded how the following responsibilities were divided:

1) Deciding what to plant;

2) Providing seed;

3) Paying the costs associated with ploughing, harrowing, and furrowing;

4) Paying the costs of chemical inputs and irrigation; and

5) Harvest labor.

Finally, I recorded how the harvest was split (in halves, $1 / 4$ to $3 / 4$, etc.). I also noted opinions that arose spontaneously in interviews regarding the nature of sharecropping, especially whether the interviewee viewed the arrangement as exploitative, philanthropic, or based upon equal needs. Many informants volunteered their perceptions regarding how sharecropping contracts had changed in recent memory, and so I noted these perceptions.

I analyzed data on sharecropping through grouping by similarities and differences. Contract arrangements for rainfed land (maize) were sufficiently different from those for irrigated land (cash crops) to warrant separate analyses. To interpret the survey, I analyzed the summarized, categorized data in triangulation with information provided in interviews and participant observation, as well as archival research. 


\section{Perceptions of a Changing Local Climate}

In addition to sharecropping, actual water scarcity and a perception of local climatic change emerged as two potentially interrelated and relevant forces of influence on the changes and continuities found in agricultural practices in Santiago. Archival research, climate data analysis and visualization, and a survey of perceptions of climate change enabled exploration of this possibility.

During the first few weeks of research, several respondents mentioned that the climate had changed significantly and played a defining role in local agricultural change. To explore this perception, during both fieldwork trips I noted spontaneous opinions on when, how, and why the climate was perceived to have changed. I then surveyed twentythree adult residents of Santiago regarding whether they perceived a change in the climate in Santiago over the last half-century. I referred to this period as the course of their life, but also recorded perceptions that they cited as opinions of their parents and grandparents. I was careful to analyze only perceptions that residents declared as their own observations, or those related by their forebears, rather than perceptions cited from news media or gossip (e.g., the sun getting closer to the earth, which two individuals mentioned having seen on television). When a change in climate was identified as having

occurred at a specific time, I recorded that date. Then, I asked whether the respondent had any theories about the cause(s) of the shift. Such ideas about causation I recorded and classified qualitatively into nine categories.

I then considered these ideas in comparison with observable changes in technology and material culture, and biophysical data regarding local climate and 
hydrology obtained from the office of the national water agency, Comisión Nacional del Agua, Cuenca Pacífico Sur ("CONAGUA"), in Oaxaca City. I obtained the data from CONAGUA by submitting a formal written request in person. After this request was processed, I met with an engineer who gave me electronic documents regarding water table depth throughout the Valley and engineers' reports to the state government regarding the water crisis in the Valley. The agency later provided me with spreadsheets of temperature, precipitation, and evapotranspiration data via e-mail in July-September of 2013. I combined data from two local stations to create a record of temperature, precipitation, and evapotranspiration for the years 1962 to 2012 that could be compared with residents' perceptions of local climatic change and explored in relationship to agricultural practices described by Kirkby (1973) and those observed in the present day.

\section{Supplemental Contextual Data}

As a form of additional triangulation and acquisition of oral histories that could provide context for understanding the changes and/or continuities in agricultural practices observed in migrant households, I interviewed additional individuals holding relevant, specialized knowledge. These included the municipal president (a Santiago native and a former resident of Mexico City who farms maize), an elderly resident who was one of Santiago's first Bracero migrants, the owner of the town's agricultural products store, the owner of one of the town's three small tortilla factories, and the great-grandson by marriage of the town's infamous landowner, Jose "El Chendino" Secundino (see page 50). I also spoke informally with the engineer in charge of the municipal well that provides running water to Santiago's urban center. Participant observation among 
numerous acquaintances developed in town offered additional contextual data. Finally, additional contextual data was provided by a graduate student at the Instituto Tecnológico de Oaxaca, Miriam Campos Cornelio, who conducted a comparison of sustainable development indicators in Santiago, the neighboring town of San Antonino, and Ocotlán for her master's thesis research (Campos Cornelio 2012a and 2012b). Ms. Campos Cornelio's thesis summarizes general demographic data for a sample of 58 households in Santiago, including information regarding migration and primary economic activity. She shared her primary migration data spreadsheets with me and I used these as the basis for presenting the broader characteristics of migration in the community.

These additional sources of qualitative data gathered in participant observation, supplemental interviews, and from archival records were interweaved with secondary sources to produce a rich description of the historical and geographical context. This data also provided substrate for contextualized, triangulated interpretation of results from mixed-methods analysis.

\section{Triangulated Interpretation}

Once summaries of the principal ethnographic survey data had established that maize production in migrant-headed households still approximates one ton per family per year, and I had completed analysis of additional data suggesting potential broader forces impacting agriculture in the landscape, I conducted an overall interpretation from the results of mixed-methods analysis. This interpretation involved triangulation of land use, production, and consumption results with data showing current land tenure contracts on both irrigated and rainfed land, data regarding perceived and actual changes in the 
physical environment, particularly groundwater, and the archival, interview and participant observation data that had enabled a historical portrait of agriculture and migration in the community. Community-wide changes in the means of productionland, labor, knowledge and capital—offered a convenient conceptual framework for synthesizing the data into speculative summaries of the potential causal factors of changes and continuities in migrant households' agricultural orientations, to be developed in future research.

\section{Researcher Positionality}

Researcher positionality forms an important aspect of any research methodology based on information gathered from human subjects. For example, a researcher's gender, race, class, physical appearance, connections to the social group, and conduct during research are all influencing factors. Reflecting on these factors helps to qualify and contextualize ("situate") the knowledge the researcher produces (Rose 1997). The findings of this study depended heavily on responses from research subjects to questions I posed to them. Consequently, establishing trust with research subjects was essential to producing reliable data. How such trust was established for this research is worth considering in reference to researcher positionality, research objectives, and research design. In this section, I outline key aspects of my positionality and actions as a researcher and relate them to the methodology chosen for this study.

Key aspects of my physical appearance are that I am light-skinned, female and look like I am from the United States. Power dynamics are at play in what being each of these things symbolizes in the context of a Zapotec farming community in Mexico, 
although I had to discover the particularities of these dynamics in the field. For example, most people that I met assumed I was married to one of the town's many U.S. migrants. (A common first question was "Whose daughter-in-law are you?") Then, when I corrected the misperception, there often remained a sense that my purpose as a researcher-which I described as forthrightly as possible — was still uncertain. Acquaintances may have sought to determine the power I might wield in their community, perhaps seeing that my race, class and nationality placed me in a certain category. For example, several new acquaintances half-jokingly asked me if I wasn't there to develop a mining operation. Indeed, on the horizon just kilometers west from Santiago was a mine, allegedly developed by an American and not currently in operation. The general uncertainty as to my purposes meant that I had allow people to form at least an initial judgment of my character before I could proceed with candid question-andanswer. A factor to my benefit was that I speak Spanish fluently with an accent and vocabulary that reflects many years working with Mexican and Central American migrants to the United States, including individuals from Zapotec communities. This made the unstructured process of expressing my identity and motivations much easier than if my language skills were less developed.

The connections I forged early on, largely through luck and partly through my position as a naïve but linguistically apt foreigner, were key to building trust with research subjects. A homestay arrangement contributed much to my acceptance in the community. Upon arrival to begin research during a rainstorm, (and following a meeting with the municipal leaders to explain my purposes and obtain their permission to allow 
me to roam freely and collect information the previous day), my taxi driver brought me to the door of a stranger who had apparently once had visitors stay. At the door, she invited me to live with her and her daughter for the five weeks of my initial field visit. I was described as "a friend from the United States," given a key, and allowed to come and go as I pleased. Figuratively speaking, she had given me a key to more than one house in the community. In making acquaintances in the street, the question that invariably followed after I denied having married a migrant from the community was, "In whose house are you living?" By responding to this with a brief genealogy ("I live on Calle Aldama, with $\mathrm{X}$, daughter of X), I showed that I had a personal connection to the community and was trusted by my host.

I always answered questions that my acquaintances asked me during research to facilitate exchange, conviviality and reciprocal forthrightness. Accordingly, I ended up describing my background and goals - that I had grown up in an urban environment; that I had traveled a fair amount; that I could cook but I had never farmed maize; that I spoke Spanish well because I studied it in school from a young age, practiced with nativespeaker relatives, attended university in Argentina; and worked as an immigration lawyer's assistant. Many people asked me why I could visit them as I pleased, but they couldn't visit me in my country. In response, I did my best to explain U.S. immigration policy, as well as my shared frustration.

After learning that I was connected with immigration lawyers, people often asked me questions about current immigration policies and laws. While I spoke about these, I made sure to explain - as the ethics of paralegal work requires - that the law is complex 
and that only a lawyer could give them an explanation of their individual immigration options. In some cases this led to me providing the contact information for the office I work for in Portland, Oregon. I also gave my own contact information out freely to anyone who asked, including my e-mail address, street address and personal phone number. I believe that this professional background and my willingness to exchange information and ideas rather than only ask questions tended to increase my desirability as an acquaintance.

Willingness to share in physical labor helped in trust-building throughout the fieldwork, as well as offering insights into processes that come though this type of engagement. Several contacts expressed satisfaction at my willingness to work with them (shucking, slicing, harvesting, or sowing — "es una chingona",2), and in some cases this ended up being a form of reciprocity for helping me with my research. However, once established, it had to be maintained. I recall when I was still weak from the diarrhea and stomach troubles that put me out of commission temporarily, I surveyed a respondent's field, then sat down in the shade with his young daughter. I wrote down math problems for her to solve in my notebook, rather than helping with the weeding. This was not initially considered a worthwhile contribution, but I managed to defend the value of math tutoring.

Finally, displays of goodwill in the form of gifts also helped me to build trust with acquaintances in the community. In each household that participated in the principal survey, I offered to take a portrait of the family. Then, I had these portraits framed in a shop in Ocotlán before I returned them. Everyone seemed to delight in the framed

\footnotetext{
${ }^{2}$ Slang word to mean "badass," or a really cool person.
} 
photographs, although my artistic choices were sometimes questioned. In addition, I brought small bottles of perfumed essential oils to the households' women during my second trip and purchased small firecrackers as Christmas gifts for the families with children. These, too, were popular offerings. Finally, I donated several books in Spanish to the municipal library during my first visit, and a small laptop computer during my second.

In order to gain access to people's time, space and ideas, and to trust that the information they provided was accurate, I had to build relationships of trust. Among some research subject populations, trust is fairly easy to secure. It may only require a uniform or a sign of authority that is acceptable to the community. By contrast, due to the long history of government abuses against indigenous peoples in Mexico, there is a general distrust for representatives of the Mexican government and researchers who symbolize government or foreign interests. The United States, with its strict immigration enforcement practices and longstanding role in mining industries in rural Mexico, is hardly more trustworthy. An emissary from the United States cannot simply arrive with a clipboard to enter homes and measure individual land holdings and expect that people will open their doors or answer questions truthfully.

In this context, the best way to gather data was to build relationships with the research subjects, and to become familiar enough with contextual issues and patterns of behavior as to know how to solicit a good-faith answer and cross-check against a spurious one. A methodology involving small samples of quantitative data and diverse sources of qualitative and contextual data thus enabled me to assess the central research 
questions within the practical constraints posed by the chosen foreign area of research. The triangulated, mixed-methods methodology allowed me to first, assess whether household-level migration had modified longstanding agricultural practices centered on producing a minimum amount of subsistence maize, and second, explore broader drivers of change in the landscape that might explain the changes and continuities observed. 


\section{Chapter Three: Study Area and Historical Background}

Historical and geographical archives provide context for exploring how longstanding agricultural institutions and transnational migration have shaped the present-day community of Santiago Apóstol, Oaxaca. In this chapter, I use primary and secondary sources to depict the physical geography of the study area, situate its farming practices within a broader historical context, provide snapshots of local agricultural production and agricultural land tenure in earlier periods, and consider potential factors driving the late $20^{\text {th }}$ century dispersion of Santiago's population. Among late $20^{\text {th }}$ century phenomena, both increasing dependence on a broader economic system that attracts rural migrants to Mexican cities and abroad and the expansion of formal education in rural communities through federal policies emerge as forces of change in Santiago's agrarian society. Characteristics of the present-day landscape and cultural traditions offer context for the central research question of whether migration by household heads has modified longstanding household-level farming practices centered on subsistence maize.

\section{Location, Topography and Climate}

The study site town of Santiago Apóstol rests in the intermontane region of the Mexican state of Oaxaca known as the Valley of Oaxaca, or Central Valley (Figure 1 and Figure 4). Its urban center sits approximately three kilometers from the Atoyac River to the west and five kilometers from the city of Ocotlán de Morelos to the east, at the geographical coordinates $16^{\circ} 48^{\prime}$ North and $96^{\circ} 43^{\prime}$ 'West. Both a town and a municipality, 
Santiago Apóstol's municipal jurisdiction encompasses several small hamlets, including San Lucas, Las Cruces, and San Sebastian in the northeastern part of the municipal territory.

The 18-square-kilometer municipal territory sits upon the high alluvium of the southern branch of the valley, at an elevation of 4,850 feet. The territory inclines east towards a rocky hill, El Cerro de las Azucenas (The Hill of The Lilies; informally, el cerro), vegetated sparsely in scrub brush, grass, and native wildflowers. Agricultural activity takes place on lands between 4,830 and 4,880 feet, at which point the piedmont soils rise into a rockier zone unsuitable for cultivation. A stream known as the Rio Chiquito lines the north and west sides of the urban center of Santiago. The stream was channelized in 1978 and now appears as a verdant bog. Two other formerly intermittent streams known as the Rio Verde and the Rio Seco are now dry paths year-round, lined with spiny sweet acacia and mesquite trees.

Historically, there have been two kinds of land for agriculture in Santiago. Lands referred to as temporal depend solely on rainfall, while those referred to as de humedad are moist soils characterized by a high water table that allows plant roots to drink directly from the earth. As recently as 1967-69, groundwater on the Valley floor was measured to be "within 3 meters of the surface during the dry season and ... [rising] to within 1 to 2 meters during the summer growing season" (Kirkby 1973, 24). Humid soils have become almost obsolete in Santiago as groundwater levels have dropped to 15 - 16 meters or more according to measurements from 2001 to 2011 (CONAGUA 2012). 


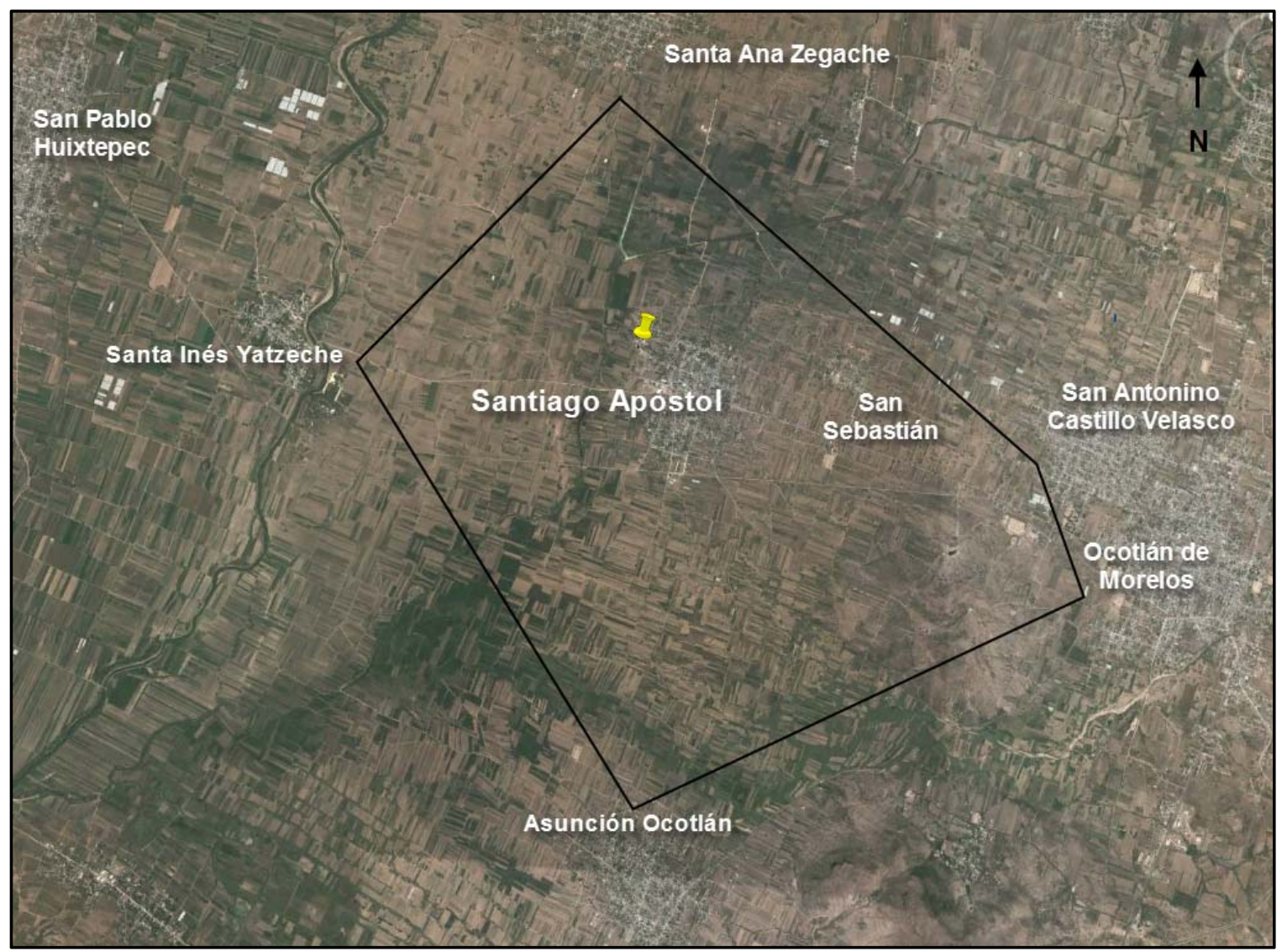

Figure 4. Santiago Apóstol and neighboring communities. Territorial boundary in black is approximate. Source: Google Earth 2012 (modified sattelite image).

Rainfed agriculture in the Valley depends on a summer rainy season spanning April to October, historically concentrated in two spikes of rainfall expected in June and September. Actual evapotranspiration generates a net water deficit in all but the months spanning June to October (Kirkby 1973, 17). The prolonged winter drought makes timing of maize plantings in April-July especially important. Farmers prepare plantings to coincide with the first downpours in June or July, and to withstand the midsummer drought known as the canícula. A second period of heavy rain most commonly occurs in August or September to allow the maize plants' full development. This pattern results 
from synoptic circulation patterns that generate what is known as the Mexican monsoon (Dilley 1993) (Figure 5a).

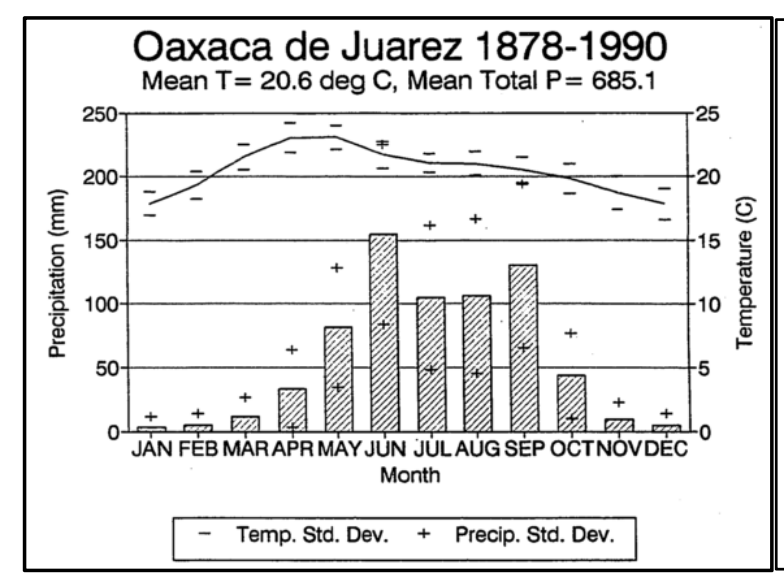

(a)

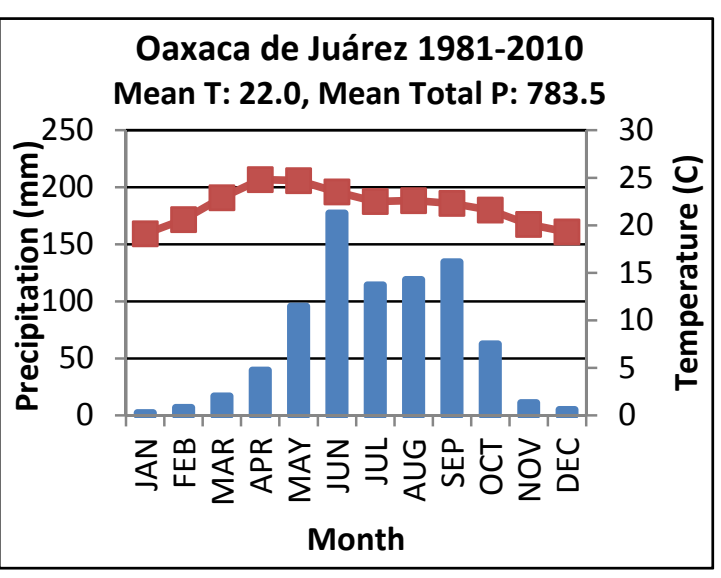

(b)

Figures 5a and b. a) Historical monthly temperature and precipitation averages in the Valley of Oaxaca. Source: Dilley 1993. b) Monthly temperature and precipitation averages in the Valley of Oaxaca 1981-2010. Source: National Meteorological Service, 2013.

Recent monthly temperature and precipitation averages from the capital city approximately 30 kilometers north of Santiago Apóstol reveal a global increase in temperatures as well as an increase in annual precipitation (Figure 5b). The Oaxaca de Juárez meteorological station data registers an increase in average temperature between the 40 year period spanning the 1920 s to 1960 s and the 30 year period from 1981-2010. The average temperatures in these two periods were $20.6^{\circ}$ Celsius and $22.0^{\circ}$ Celsius, respectively (Kirkby 1973; National Meterological Service 2012). This $1.4^{\circ}$ Celsius increase in temperature may be greater than the temperature increases taking place in Santiago, since the city of Oaxaca forms an urban heat island and can thus be expected to register higher average temperatures than its surrounding, less-developed areas. 
Nevertheless, a significant rise in temperature throughout the region, urban and rural, may be underway.

Concurrent with this potential rise in global temperatures, annual precipitation has also followed a rising trend, according to data from Oaxaca de Juárez. Between 1878 and 1990 the mean annual precipitation was $685.1 \mathrm{~mm}$. In the period 1981 to 2010 , mean annual precipitation was $783.5 \mathrm{~mm}$, an increase of 14\% (Figures 5a and b). Previous studies demonstrated the crucial importance of water balances in the summer months on agriculture, using inter-annual and intra-annual analyses (Kirkby 1973, Dilley 1993). An updated analysis of inter-annual and intra-annual variation in precipitation and evapotranspiration (a product of temperature and available water) influencing maize agriculture in the Valley is beyond the scope of this study. However, visualizations of both temperature and precipitation records from the climate stations closest to Santiago are discussed in Chapter 5 alongside analysis of residents' perceptions regarding local climatic change.

\section{The Evolution of Santiago's Farming Society: From Closed, Corporate Community to Transnational Town}

Oaxacan peasants' integration into international labor markets beginning in the mid- $20^{\text {th }}$ century marks a profound transition from at least two centuries of sedentary farming in closed, corporate communities (Nolasco 1992). Indigenous communities were marginalized geographically, politically, and economically throughout Mexico's history as an independent state. In this context, the importance of independent, primary production activities, and traditional social and economic institutions of reciprocity and 
redistribution that cohered the sedentary population in a web of interdependences were key to survival.

However, the challenges of subsistence-oriented production on marginal lands following Spanish conquest, and lands that became inequitably distributed following land reforms of the $19^{\text {th }}$ to $20^{\text {th }}$ century were substantial. Thus, the newfound mobility of Oaxacan peasants engaging in the global economy as wage laborers from the mid- $20^{\text {th }}$ century on is a fact that few in Santiago lament. Still, migration has brought its own set of challenges for this historically sedentary, agricultural community. The prevalence of maize in the landscape is one indication of the strength of subsistence farming traditions that have evolved over approximately three thousand years. Nevertheless, the impacts of migration on maize farming activities may suggest a new trajectory for agriculture in Santiago: the household-level agricultural practices of migrant households presented in the following chapter will help to pinpoint whether risk-averse traditions in agriculture centered on subsistence maize remain important for migrants and their families.

\section{Pre-Hispanic Settlement}

The first settlement within the current territorial expanse of Santiago was San Lucas, now a hamlet or agencia of the municipality which lies against the northwestern edge of Santiago's urban center. As legend goes, the founders of Santiago descended from the mountains in search of better land for agriculture and arrived at San Lucas after striking out in their first settlement location. Early agriculture in the Central Valley dates to $1500 \mathrm{BC}$ (Dilley 1993, 164) and it is therefore possible that distant ancestors of Santiago's present day migrants and maize farmers were cultivating in the Central Valley 
some three millennia ago. Early crops included the commonly intercropped maize, squash and beans, as well as avocados, cactus fruit and chilies (Winter 1988, 63). The community likely carried on subsistence farming through distinct periods of political and economic integration, from the city-state of Monte Alban and its substantial regional markets to the extractive feudal city states led by Zapotec nobles, and ultimately, to Aztec rule under the emperor Moctezuma. Amid the crumbling stone walls of the old Catholic church of San Lucas sits a large, stone engraving of a warrior interpreted locally as the Aztec emperor. The Catholic church of Santiago Apóstol, just 500 meters away from this stone engraving, was first erected in 1698 — at that time with a straw roof (Maya Padilla and Cortes Cortes 2011).

\section{Colonial Period}

The Spanish arrival in Oaxaca in 1519 brought dramatic changes in agriculture, along with a native population collapse of immense proportions, estimated between 72 and 87 percent of Oaxaca's population (Dilley 1993, 169). Before Spanish conquest, there were no beasts of burden, nor was the wheel a common feature of productive life. The wooden ox-plough used today, along with cattle, horses, donkeys, goats, sheep and pigs that make up common elements of the present-day Santiago household, arrived with the Spanish.

Several changes ensued while Spain asserted control over Oaxaca, including introduction of new crops and animal species. Old World crops introduced into Oaxacan agriculture and cuisines included chick peas, onions, garlic, radishes, pomegranates, melons, and varieties of citrus (ibid, 13-15). These have become staples in native 
Oaxacan gastronomy and remain visible in Santiago's fields and courtyards. In the $17^{\text {th }}$ and $18^{\text {th }}$ centuries, land area used by native communities for small domesticated animals decreased (Reina 1988, 232). Crop rotation also began in this period (ibid). There was substantial degradation of agricultural lands in the Central Valley due to cattle grazing. Santiago's territory allegedly suffered damage from Spanish cattle in the $16^{\text {th }}$ century (Taylor 1972, 119).

The Spanish increased state presence in oversight and administration of territorial conflicts in Oaxaca. However, territorial land holdings generally remained under native communities' control, under separate Indian Laws recognizing the communal nature of indigenous lands and representation (Reina 1988).

\section{Independent Mexico}

The Wars of Independence in the first half of the $19^{\text {th }}$ century brought dramatic changes to Oaxacan society and productive activity. First, Oaxaca's population had decreased by $31 \%$ by the end of the Wars of Independence (Reina 1988, 222). Second, its export-oriented agricultural economy, supplying dyes and textiles to Europe, collapsed. European nations' colonization of India and Africa brought new, cheaper sources of dyes and cotton, and English textiles were sold in Mexico, undermining Oaxacan production of these commodities (ibid, 228). Cochineal production dropped $89 \%$ over the course of the Wars of Independence (ibid, 230). The end of the export-oriented colonial era in Oaxaca resulted in a productive re-orientation towards maize and other subsistence crops, as well as animal husbandry (ibid, 229-232). 
Political liberalism in the $19^{\text {th }}$ century demanded an end to the colonial laws that recognized indigenous social organization, and an end to these communities' autonomy of self-determination (Reina 1988, 221). The Indian Laws were nullified in 1824, as the Independence period brought new liberal politics to Mexico's nation building (ibid, 238). Political goals in newly independent Mexico were economic development, elimination of racial difference, and problems deriving from the "privileges" of certain sectors, including the Catholic Church and indigenous social groups. Indeed, the new political goals clashed directly with the political desires of most indigenous Oaxacan communities. Under the new political goals,

"[r]epresentation was to be individual and administration collective. This issue, along with others, would be the source of many indigenous rebellions, as these communities wanted collective representation and an administration proceeding from their own logic of reproduction" (Reina 1988, 221; my translation).

The $19^{\text {th }}$ century involved government seizures and privatization of indigenous and Church lands, as well as colonization of relatively less-populated regions. In Oaxaca, this unfolded a century of numerous and especially tenacious rebellions on the part of native society, in which production of subsistence crops was key to survival.

Quashing the rebellions and re-establishing the Independence goal of economic development for competition among world nation-states were two aims fervently advanced by Porfirio Diaz, dictator of Mexico from 1877-1910 (Esparza 1988, 288). Statistics show that the production of maize, beans and wheat in Oaxaca remained relatively stable in the two decades preceding the Porfiriato dictatorship, but dropped substantially despite continuous population growth at the beginning of the 1890s, as policies of private land distribution and adjudications intensified (ibid, 300). The politics 
of liberalism as practiced under the dictatorship of Porfirio Diaz centered on diversifying commercial products for export rather than allocating resources to basic food crops, at substantial social cost. The increased production of plantation crops characteristic of capitalist development, including sugar, tobacco, and most importantly, coffee, marked a progressive deterioration in the social relations of production in Oaxaca (ibid, 306). These plantation crops brought not only harsh conditions for laborers through their highintensity production technologies, but also due to the fact that profits from these exports were subject to sudden changes in price on the international market (ibid, 301-306).

Nevertheless, the Central Valley maintained a strong production of basic food staples during the Porfiriato. From 1909 to 1911, at the end of the Porfiriato, the Central Valley accounted for 54 percent of the state's maize production, 44.99 percent of its production of beans, and 51 percent of its wheat (Esparza 1988, 339-341). The Central Valley appears to have remained a breadbasket for plantation labor forces throughout Oaxaca and for the mercantile classes of Oaxaca City.

\section{Revolution and Land Reform}

The extreme nature of the late $19^{\text {th }}$ century pursuit of modernization, industrialization, and land privatization under Porfirio Diaz soon catalyzed a reaction: Mexico's 1910 Revolution, with its famous slogon, tierra y libertad: land and liberty. However, far from reflecting these emancipatory ideals, local oral history in Santiago portrays the revolutionary and post-revolutionary years as a time of isolation and fear, marked by marauding bands of burglars. Moreover, there is evidence that Santiago's population found itself in a deprived state following the Mexican Revolution, despite the 
new focus on returning land to Mexico's indigenous peasantry. In 1891, when the Oaxacan state governor decreed Santiago Apóstol a municipal ayuntamiento (Maya Padilla and Cortes Cortes 2011), the approximately 18 square kilometers of land pertaining to its political jurisdiction may have been entirely communal. Land tenure arrangements were likely based on usufruct, or the right to use and derive benefit, but not to sell. Perhaps ironically, the transformation of Santiago's farmland into small fractions of pequeña propiedad, titled private property, appears to have occurred mostly in the early $20^{\text {th }}$ century.

Under Article 27 of the Mexican Constitution of 1917, the Mexican state had asserted the right to seize privately-owned land for the creation of communal territories under different designations (among these, the ejido, an agrarian land use community in which the members, known as ejidatarios, hold use-rights but not inalienable ownership). However, restitution depended on presenting documentary evidence of prior communal or individual ownership, as well as the proximity of a hacienda or other large, individual landholding that could be redistributed. For this reason, the new law failed to produce its intended effect in Santiago. In receipt of a territorial usurpation complaint and request for land restitution from Santiago's municipal president and several aspiring ejidatarios in 1920, the National Agrarian Commission eventually sent for an engineer to conduct a survey of Santiago's land and population (Registro Nacional Agrario 2012). While the Commission considered that Santiago's people were indeed in need of land, no land restitution was ever granted in response to their request (ibid). 
A 1935 survey of Santiago prepared by the Agrarian Commission's engineer and now held in the Agrarian Registry archive in Oaxaca City offers a useful historical snapshot of Santiago's demographics and agriculture in the post-revolutionary decades. In 1935 , the population of Santiago was $2066^{3}$, including 890 heads of household, with $598(67 \%)$ of these household heads holding titles to a parcel. Communally-held lands at this time still amounted to 1510 hectares, over three-quarters of the 18 square kilometer territory of Santiago today. At this time Santiago's land was noted as being of "average quality," encompassing rain-dependent agricultural lands, humid soils with a high water table, and some land classified as "appropriate for raising animals." The Agrarian Commission engineer measured arable topsoil at 30 centimeters and named corn and beans, with farming costs per hectare of 5 and 7 pesos, respectively, as the community's principal crops. He classified the climate as warm, with annually abundant rain. Most inhabitants dedicated themselves to agriculture but lacked sufficient land to meet subsistence needs. Indeed, their land constraints were significant. Even if the 890 heads of households documented in the 1935 census were to have equitably shared the 1510 alleged hectares of communal farmlands, there would be just shy of 1.7 hectares for each household. One third-party witness to the Agrarian Commission decried the compromised situation of Santiago's farmers: they were so constrained as to survive only by sharecropping neighboring communities' lands several kilometers away. (Registro Agrario Nacional 2012.)

\footnotetext{
${ }^{3}$ It appears likely that young children were not counted in this survey based on the large proportion of household heads in the total population count.
} 
As the land privatizations of the $19^{\text {th }}$ century shifted focus to $20^{\text {th }}$ century remedial actions of restitution post-Revolution, there was an increasing urgency in privatizing communal land holdings and obtaining written documentation of one's pequeña propiedad. Some found greater success in this than others. Santiago was never a large, privately-owned estate, or hacienda, which meant in part that there was no obvious place from which to redistribute lands. Furthermore, the new importance placed on holding titles to land appears to have aided in a certain degree of inequitable redistribution.

For example, local oral history tells of one particularly shrewd land-holder who consolidated large holdings — according to most accounts, during the $1930 \mathrm{~s}$ - by taking advantage of crop failure and famine. Jose Secundino ("Chendino") had accumulated large stores of maize through scrupulous attention to his farming and accounts. When the local harvest of maize failed for more than one year, his supplies of grain lasted where others' rapidly diminished. Desperate farmers soon arrived to beg rations from the rich farmer's home, where entire rooms still brimmed with grain. They were obliged, but at a price. In exchange for his maize, the landowner requested their land titles. So it was that the unfortunate, hungry farmers were forced into sharecropping their own land. Even today, the story of Chendino is repeated throughout the community, and the local grandchildren of this landholder remain subject to envy and distrust by some who say their ancestor made a pact with the devil. This local history demonstrates how very difficult life was for a great number of Santiago's farmers in the decades of isolation following the Revolution. 
The expanded mobility of Mexico’s indigenous peasants from the 1940s onward, migrating for wage labor in Mexico's industrializing urban areas during the post-war period of economic growth known as the Mexican Miracle, and as agricultural laborers in the United States, emerged as a welcome opportunity for Santiago's land-constrained farmers. Still, migration for wage labor abroad or in Mexican cities has carried its own set of challenges for migrants, their families, and the community at large.

\section{Transnational Migration}

In Santiago, migration has been heavily oriented to destinations in the United States, although many have also traveled to Mexico City. A household survey conducted in 2009 revealed that among 58 randomly sampled households in Santiago Apostol, $34.5 \%$ had one or more absentees (Campos Cornelio 2012a). A total of 36 absentee migrants were counted, making up $14.2 \%$ of the population surveyed (ibid). Of these 36 migrants surveyed, 28 travelled to the United States and 8 went to Mexico City. Eighteen of the U.S. bound migrants had known destinations in the United States; fifteen of them in Oregon. If this sample were to represent the broader migrant population, some $83 \%$ of migrants from Santiago would be destined for Oregon. The heaviest outmigration period found in this study was 2001-2005 (Campos Cornelio 2012b).

Historical censuses suggest that outmigration from Santiago peaked between the late 1990s and 2008 (Table 2). The community's population diminished in 2005, coinciding with a peak period for all Mexican migration to the United States. The proportion of women in the town also rose, indicating emigration by the males of the community. The number of inhabited dwellings in Santiago also diminished during these 
peak years of Mexican emigration to the U.S. A 2010 census counted 1,247 dwellings but only 896 inhabited dwellings in Santiago, indicating both the level of emigration as well as its impacts, as many semi-permanent emigrants from Santiago maintain bonds to the community through home renovations and new construction. For the first time in the 2010 census, uninhabited homes and seasonal-use homes were also counted, at 310 and 41, respectively. Thus, almost 30 percent of all dwellings in Santiago in 2010 were uninhabited or seasonally inhabited. With the demographic landscape thus transformed by migration, it is reasonable to expect substantial social and economic impacts in the community.

Table 2. Historical Population and Dwelling Size in Santiago Apóstol. Source: INEGI 2010, 2013.

\begin{tabular}{|l|l|l|l|l|l|}
\hline Census Year & Population & $\begin{array}{l}\text { Percent } \\
\text { Women }\end{array}$ & $\begin{array}{l}\text { Total } \\
\text { Dwellings }\end{array}$ & $\begin{array}{l}\text { Inhabited } \\
\text { Dwellings }\end{array}$ & $\begin{array}{l}\text { Dwellings } \\
\text { with Non-Dirt } \\
\text { Floors }\end{array}$ \\
\hline 1990 & 4,513 & 54 & --- & --- & 154 \\
\hline 1995 & 4,202 & 53 & --- & 823 & --- \\
\hline 2000 & 4,048 & 55 & --- & 816 & 329 \\
\hline 2005 & 3,296 & 56 & --- & 725 & 337 \\
\hline 2010 & 3,616 & 56 & 1247 & 896 & 355 \\
\hline
\end{tabular}

According to the interviews and participant observation conducted in this study, international migration from Santiago gained traction in the $1980 \mathrm{~s}$, increased in the $1990 \mathrm{~s}$ to mid-2000s, and is only now diminishing. The first international migrants from Santiago were recruited as part of the United States Bracero worker program in the 1940s, although it is unknown how many from Santiago participated in this program. One individual explained that when he left in approximately 1950, he was the only worker recruited from Santiago. While migration may have increased some through the 1950s, '60s and '70s, it is clear that momentum picked up substantially in the 1980s, in concert 
with new demands for low-wage workers in the United States as well as news of the 1986 agricultural worker amnesty, also known as the Immigration Reform and Control Act also known as IRCA (Rees 2006). The IRCA legalized the presence of migrant agricultural workers (Seasonal Agricultural Workers, or SAWs) and allowed them in turn to submit petitions for their family members to migrate lawfully (Goodman and Hiskey 2008, 169). Most migrants from Santiago holding lawful immigration status in the United States are either principal or derivative beneficiaries of the IRCA law.

Class and migration are often linked, whereby those with greater access to financial and social resources demonstrate greater mobility (Stephen 2007). Nevertheless, Santiago's migrants appear to come from a range of social classes. While money and social ties in the United States greatly facilitate both documented and undocumented migration, contacts and cash have not been prerequisites for all individual migrants. Indeed, migration has been one strategy for extremely poor, landless residents to change their lot. When there was a train that ran through Santiago, connecting to Oaxaca City and eventually to border towns, migrants rode the train to wage labor opportunities in Baja California or Sinaloa, eventually saving enough earnings to cross into the United States. Today they either save or borrow money for plane passages to the border. Migrants have included women and men, although women tend to follow their fathers, brothers or husbands rather than lighting out alone or joining friends abroad.

In the United States, most Santiagueños work in manufacturing, agricultural, and service sector jobs. The largest population cluster abroad has emerged in Eugene, Oregon. Significant numbers have also settled in Salem, Oregon; Half Moon Bay, 
California; and Los Angeles. Others mentioned working in North Carolina, Nebraska, Florida, and Hawaii. Santiagueños in Oregon celebrate the town's namesake saint's day festivities commencing on July 27 each year and other local holidays in a community that has taken root in Springfield and Eugene. They enjoy tortillas and other items shipped direct from Santiago and purchase videos of local celebrations in Santiago by a fellow migrant whose livelihood includes this video distribution business.

International migration from Santiago appears to have slowed with the recent global recession as well as increases in border security that have made undocumented migration both more dangerous and more costly. In this, Santiago falls in step with changing rates of migration from Mexico in general (Passel, et al. 2012). Santiago gained population between 2005 and 2010 after steadily losing it for three consecutive five-year census periods (INEGI 2013). The insecurity of work in the United States since the 2008 recession and tightened border control in particular have made potential repeat migrants now in Santiago wary of making the journey North again. In addition, the death of a young migrant from Santiago in the borderlands and stories of unsuccessful attempts to cross have been a powerful deterrent for some. While many professed their continuing desire to work for a few years in the United States, most are unable to pay the increased prices of facilitated unlawful entry, reportedly from upwards of $\$ 2,000$ (USD) for guidance across the desert to as high as $\$ 10,000$ (USD) for transport through border checkpoints in a vehicle. Other experienced migrants indicated that even if they were given opportunities to return the U.S. lawfully, they would not pursue them, as they no longer wished to be divided in two places. One of them, age 30, told me he had "found 
himself" spiritually in Santiago and would not be leaving again, despite a marriage that made him eligible for lawful travel. Many migrants returned from the United States in the post-recession years of 2009 and 2010 and are now making a living from diversified activities in agriculture, taxi driving, and local retail.

Santiago's traditional social, political and economic structures have undergone changes as a result of migration. Some changes have demanded reconfiguration of practices that evolved to serve the needs of a closed, corporate and sedentary population. The challenges are especially felt by local leaders who name emigration abroad as the foremost challenge to local community development. The current mission of the municipal government is to "break with that which prevents the community from economic and social advancement, so that inhabitants who emigrate abroad can be retained within the community" (Maya Padilla and Cortes Cortes 2011).

\section{Culture, Politics and Economy}

Both migration and governmental programs targeting rural Mexican communities have posed challenges and opportunities to the social organization of a community that evolved to accommodate a sedentary, agricultural population. Changing social, political and economic institutions reflect the influence of migration and government educational policies.

Santiago's inhabitants are ethnic Zapotecs and speak an indigenous language referred to locally as either deez-uhl or idioma, which means "language" in Spanish. Their language belongs to the Otomangue linguistic family (Maya Padilla and Cortes Cortes 2011). Adult men in Santiago today have rarely completed more than a primary 
education in Spanish while adult women of the oldest generation were not sent to school at all. As a result, the local Zapotec dialect remains the primary language among residents. However, recent federal policies to expand education in marginal, rural populations through television-based instruction programs (telesecundarias) and federal household-level subsidies for school fees and supplies have produced a new level of cultural and economic integration between Oaxaca's rural communities and its cities (Santibañez, et al. 2005; Mason and Beard 2008, 249). As a result, younger generations in Santiago ubiquitously speak and write Spanish. Some even attend university in Oaxaca de Juárez, commuting via bus to their classes while continuing to live in Santiago with their parents. This regional mobility contributes to new cultural practices (e.g., forms of dress) and professional aspirations among younger generations that contrast with those of their parents.

Santiago's political structures are grounded in principles of participatory, autonomous governance. Local political organization in Santiago follows the usos $y$ costumbres system, a traditional form of communal municipal governance separate from the federal and state political party system. Under usos y costumbres, a civil hierarchy based on service to the community governs appointments of male community members to municipal cargos, or service posts. The government consists of a popularly elected municipal president and a board of leaders fulfilling cargos, each in charge of a different aspect of local governance during his three-year tenure. Appointments in Santiago include directors of housing, education, ecology, security, health and culture/recreation. A sindico, or fiscal controller and judicial representative, oversees all allocations of 
municipal funds, taxes and land transfers. Other positions include a municipal secretary and treasurer.

Migration and formal education that pulls younger generations to urbanized professions away from the community tends to undermine these traditional forms of participatory governance even as they change to accommodate cultural and economic transformation. Under the cargo system of community organization, males from the community were traditionally called to unpaid leadership service in the municipality. Unpaid service was made possible by an economic structure grounded in subsistence farming and extended family support. However, those municipal cargos that demand fulltime attention now include monetary compensation. In addition, women who were formerly excluded from the cargo system now serve in positions related to accounting, secretarial work, health, and education.

By contrast, the community tradition of tequio, a one-year mandatory position of community service (e.g., the obligation to clean the school weekly for the duration of the appointment) remains unpaid. As a result, migrants and intending migrants often attempt to evade unpaid community service positions that would conflict with plans for working abroad. If called to serve a tequio position on the $6^{\text {th }}$ of January, when positions are allocated among current residents, individuals must comply or face fines and jail time. However, if unable to serve, individuals can now pay another member of the community to take up their unpaid tequio service position for a salary of approximately $\$ 5,000$ to $\$ 10,000 \mathrm{MXN} .{ }^{4}$ Migrants are not called to service unless present in the community leading up to the January $6^{\text {th }}$ appointments. Those who do not wish to return to the

\footnotetext{
${ }^{4}$ The equivalent of approximately $\$ 400-800$ U.S. dollars by the 2012 exchange rate.
} 
community for more than a short visit generally arrange trips either well before or after January $6^{\text {th }}$ to avoid community service assignments.

Integration with state-government directives and expanded mobility have also brought economic change. The economic systems of provisioning that developed in closed corporate communities prevalent throughout rural Oaxaca, including Santiago, are relatively more embedded in social relations than the capitalist market-oriented provisioning structures that characterize the Mexican national economy and that of its constituent states and urban centers. In Santiago, as in other towns throughout southern Mexico, institutions of reciprocity and redistribution are ubiquitous, including fictive kinship ties that involve material obligations and benefits and mandatory public service. Community-wide, multi-day fiestas involve a general distribution of food. Fictive kinship institutions such as compadrazgo involve the exchange of goods and services essential for human well-being.

Institutions of reciprocity extend to the means of agricultural production, such as labor reciprocity through guelaguetza. This economic institution involves calling upon a friend or relation, such as a compadre or a son-in-law, to perform a day's labor in one's own interests knowing that, at some time in the future, this labor will be reciprocated and one will be called to work on a day chosen by the friend or relation. Another economic institution is trueque, whereby the verb, cachar un trueque, refers to direct exchange of goods. For example, a woman with tortillas to sell may exchange these tortillas directly for the firewood brought to market by another woman from a nearby mountain community. These traditional economic institutions for primary producers and home- 
based manufacturers appear to persist in Santiago alongside fully monetized provisioning structures.

In Santiago, the agricultural economy remains a primary basis for work and provisioning. A 2009 survey of 58 households demonstrated that $39.7 \%$ of household heads dedicate themselves principally to agriculture. In practice, however, almost all households appear to diversify their incomes and thus the number of households with active agricultural activities is likely much higher. Santiago's traditional agricultural economy is characterized by low-risk orientations that make comprehensive use of the maize plant by renewing it for the agricultural cycle and using it to feed household animals for home consumption, agricultural labor, and sale as meat. The traditional household economy is heavily bound up in maize traditions for which every part of the corn plant is used for human and animal provisioning. Grain is saved as seed, consumed by humans as tortillas (thin, maize flatbreads), tamales (stuffed, steamed maize dumplings), atole (a hot maize drink), tejate (a cold maize drink), and other preparations, and also consumed by household fowl. Corn husks, or totomozle, are used to prepare tamales and also fed to animals. Dry maize plant leaves on their stalks, known as zacate, are harvested along with the dry corn cobs. The zacate is fed to the beasts of burden (horses, oxen, donkeys and mules), goats and sheep, and also mixed with animal dung as a soil preparation.

Santiago is regionally known for its tlayuda, a large (dinner plate-sized), slightly crispy corn tortilla that women from Santiago vend in the nearby city of Ocotlán, along with the fruits, vegetables and flowers grown in the community. A recent demographic 
survey conducted within the municipality estimated 150 professional tortilleras making these tlayudas for daily sale both in Santiago and in Ocotlán (Maya Padilla and Cortes Cortes 2011). In addition, there are some 20 female cooks hiring their services out for the constant rotation of large local parties and ceremonies. A number of women sell the ubiquitous breakfast maize drink, atole, out of their homes each morning. In addition, women prepare and sell the traditional beverage tejate, made with a base of ground maize and chocolate froth. Other women are full-time tamaleras, preparing filled maize dumplings wrapped in cornhusk and steamed for sale locally and at the market in Ocotlán.

Beyond the array of employments they hold in food preparation, Santiago's women generally operate the town's several electric mills that serve the local maize economy. Like other business enterprises in Santiago, the millers sell their services out of the street-front room of their homes, where they have two electric mills that can process wet ingredients and dry ones. Service hours begin as early as 2 a.m. for the many tortilleras in the community. The millers grind the lime-soaked corn (nixtamal) used to prepare tortillas, tamales, and atole, as well as the chocolate, toasted mole spice blends, and even dry beans that require milling for certain local dishes. These additional marketbased activities that depend upon maize lend support to the importance of this crop for levels of the economy at a remove from primary production.

In addition to maize-based economic activities, households diversify their livelihoods with several other strategies. Many of these can be seen in the everyday comings and goings of the town. Most agricultural households grow and sell a variety of 
local cash crops, either directly or through middlemen eager to purchase and re-sell the harvest if the price is right. Many raise animals for local sale or at the livestock market that takes place weekly in neighboring San Antonino. At Santiago's daily open market in front of the church, dozens of women and a handful of men set up their stands or stools to vend produce, flowers, eggs, and prepared foods such as tamales every morning until shortly after the church service ends. Bakers vend freshly baked, wood-fired breads inside the adjacent market building. On Thursdays and Sundays only, there is also freshly butchered chicken, pork and beef for sale. Some vendors sell exotic fruits and vegetables (for example, potatoes and apples) purchased from the central produce market in Oaxaca City in addition local produce and flowers. Other wares sold out of vendors' homes, on the street, or at market include sewn or knitted clothing items, embroidery, and icecream.

With increases in communication, transportation, and regional urbanization, Santiago's economy has evolved to encompass an expanding array of merchant and service professions. There are various shop owners, both men and women, who vend bottled water, miscellaneous foods and household items out of the street-side rooms of their homes. Small shops often have a refrigerator supplied by the Coca-Cola or Pepsi company, in which only that corporation's products may be stored. A variety of beers and mescal, the traditional agave based liquor, are sold in most food and sundry businesses. In addition, a pharmacy, beauty shop, and hardware store line the central street. Most of these commercial enterprises are actually homes set up to accommodate a business orientation in the front room. Manufacturing enterprises in Santiago include three tortilla 
factories. The Maseca flour-based soft tortillas from the tortilla factories are locally considered an inferior product to the handmade tlayuda. Still, factory tortillas are purchased by many women on days of rest from tortilla preparation or when the local tortilleras have already sold their home-made tortillas in Ocotlán.

Close ties with markets in the neighboring market city of Ocotlán support a demand for motorized transportation. Two car-taxi and two motorcycle-taxi collectives operate out of Santiago, shuttling local vendors to and from the market city of Ocotlán four kilometers away for a fee of $\$ 5 \mathrm{MXN}$ one way. In one case, a husband and wife alternate as chauffeurs of their motorcycle taxi, suggesting that taxi driving may not be a males-only occupation for long. Several migrants who return to the community take up posts as taxi drivers or policemen, although most do this in addition to primary production activities.

$* * * * *$

Santiago has evolved over hundreds and perhaps even thousands of years as a sedentary agricultural community whose subsistence agricultural traditions were essential to the survival of its people through the Mesoamerican, Spanish colonial, Independence and post-Revolutionary historical periods. Archival and secondary sources show that land redistribution laws following the Mexican Revolution did not increase the land holdings of Santiago's indigenous farmers, either collectively or individually. Traditional economic and social institutions in Santiago reflect a degree of longstanding isolation and autonomy from national and state-level politics, yet these are undergoing change. Timeintensive community leadership positions, formerly performed for prestige and social 
standing, are now salaried, and others have opened to include women as part of the public governance sphere. Government support for formal, rural education in Spanish since 1998 has impacted the role of children in the local economy. Motorized transportation infrastructure and communication technology have facilitated increased economic integration.

Among recent economic shifts, international migration appears as a defining force of change in Santiago's landscape and cultural traditions. Only in the past thirty years has Santiago experienced the immense challenges and opportunities of maintaining political, social and economic traditions while a significant chunk of its population engages in international labor markets. But does this engagement produce a break with longstanding subsistence agricultural practices? For households headed by migrants currently away or returned to Santiago, have choices in agriculture changed? In the next chapter, I present the results of the primary survey of agricultural land use, maize production, and maize uses among families with migrant heads-of-household in Santiago, to address the central research question of whether international migration has modified longstanding household-level agricultural practices historically centered on maize production. 


\section{Chapter Four: Maize Production and Use in Migrant-Headed Households}

In this chapter, I present and analyze data gathered from field surveys and household interviews regarding the farming activities and strategies of 19 migrant households. These data include the sampled households' basic demographic characteristics, migration profiles, agricultural land holdings, labor and technology choices, cropping choices, harvest outcomes, and uses of maize. Descriptive statistical summaries and qualitative analysis enable comparisons with the traditional maize production goals and methods documented by Kirkby (1973), and in particular, analysis of whether migrant households are focusing primarily on cash crops or adopting improved maize varieties and technology packages as part of a reorientation towards a more commercial agricultural model.

The data presented indicate that migration by the head of household has not generally modified longstanding risk-averse agricultural practices which formerly centered on producing a minimum amount of subsistence maize. Rather, production of rainfed maize by migrant households, at levels that generally approximate those observed in the region 50 years ago and with many of the same methods, appears to reflect a continued desire to guarantee family food supply through risk-averse provisioning methods. 


\section{Migrant Household Profiles}

For convenience, I call the 19 farming households headed by men who had migrated in the past or by women whose husbands were currently working abroad, "migrant households." In this section I outline their basic demographic and migration characteristics.

Migrant household size ranged from 3 to 10 persons, with an average and median of about five persons (Table 3). The age of the migrant household heads ranged from 29 to 74 years, with an average age of 52 years. All had made their first trip to the United States between 1983 and 2005 (ibid). None of the migrants household heads surveyed had made more than three trips to the United States (ibid). The average time spent in the United States was 8.6 years and the median time spent abroad 6 years (ibid). Three migrant household heads were currently abroad. Most others had returned to Santiago within the past decade. In two cases surveyed, both male and female household heads had migrated.

In the households surveyed, migration circuits have continued for the second generation. Twelve of the nineteen counted adult children (Table 3). Eleven of these counted adult children who had migrated. A mean 54 percent of adult children of these household heads had migrated, and either remained abroad or had returned to the community (ibid). 
Table 3. Household Migration Profiles.

\begin{tabular}{|l|l|l|l|l|}
\hline \multicolumn{5}{|c|}{ Migrant Household Heads (N=19) } \\
\hline & Mean & Median & Low Value & High Value \\
\hline $\begin{array}{l}\text { Year of first migration to } \\
\text { U.S. }\end{array}$ & 1993 & 1992 & 1983 & 2005 \\
\hline $\begin{array}{l}\text { Year of most recent } \\
\text { return (16 of 19; 3 not yet } \\
\text { returned) }\end{array}$ & 2003 & 2006 & 1985 & 2012 \\
\hline Number of trips & 1.6 & 1.5 & 1 & 3 \\
\hline $\begin{array}{l}\text { Total number of years } \\
\text { spent in the U.S. }\end{array}$ & 8.6 & 6 & 1 & 20 \\
\hline Number in household & 5.4 & 5 & 3 & 10 \\
\hline $\begin{array}{l}\text { Total returned U.S. } \\
\text { migrants in household } \\
(16 \text { of 19) }\end{array}$ & 1.4 & 1 & 0 & 4 \\
\hline $\begin{array}{l}\text { Number of school-age } \\
\text { children in household (11 } \\
\text { of 19) }\end{array}$ & 1.5 & 2 & 0 & 4 \\
\hline \multicolumn{4}{|l|}{ Household Heads Surveyed Who Have Adult Children (N=12) } \\
\hline Total Adult Children & 6 & 5 & 2 & 15 \\
\hline $\begin{array}{l}\text { Total Adult Children } \\
\text { Migrants }\end{array}$ & 3.3 & 2 & 0 & 10 \\
\hline $\begin{array}{l}\text { Percent Adult Children } \\
\text { Who Are U.S. Migrants }\end{array}$ & .54 & .58 & 0 & .67 \\
\hline
\end{tabular}

While data on exact remittances and savings resulting from migration were not gathered, in numerous conversations it became clear that remittances and savings from migration were not always substantial, and that they were often used for daily household expenses, home construction, and consumer goods, as has been found in other Central Valley communities (Cohen and Rodriguez 2005, 53). The three absentee migrants included in this study were sending remittances to their wives. However, it was apparent that not all migrants send remittances consistently and that migrants' earnings and spending behaviors vary. Some return migrants said they had gone through periods of not sending money when they were abroad. Others said that the money they were able to earn 
abroad amounted to little when the costs of trips and supporting oneself abroad were considered (e.g., the higher cost of housing, food, electricity and water in the United States).

Several of the households with adult children abroad said they did not count on regular remittances from children, or that they did not ask for them because their children had established their own families to care for. Some mentioned that their children had told them finding good work in the current economy was difficult.

\section{Household Land Use and Maize Production}

A combination of land ownership and land tenure arrangements form the basis of all farming activity in the community, as renting land through monetary payment is not practiced. Most households own some land, however small. Those who do not own land sharecrop or raise crops on borrowed farmland.

Among the migrant households surveyed, land ownership ranged from none (four cases) to 14.5 hectares. Five households sharecropped land, four cultivated on borrowed land (without requirements to give any product to the owner), and two contracted a portion of their owned land out to sharecroppers (Table 4).

Kirkby (1973) found that the land use survey area encompassing part of the territory of Santiago Apóstol was "mostly devoted to dry-farmed corn production which varies in area [between years 1967-1970] from 71 to 86 percent" $(1973,100)$. In comparison, the migrant households surveyed in 2012 planted an average $74 \%$ of their land holdings with maize, and a median of $82 \%$ (Table 4 ). Land use among the households surveyed thus mirrors historical uses in the region (Kirkby 1973). 
Irrigated land has become more difficult to access due to the high costs of digging and deepening wells, possibly influencing the continuity in rainfed maize agriculture observed. In the late 1960s, Kirkby (1973) documented that cultivators dug new wells an average of every two years for cash crop irrigation. The depth to water table was at that time 1-3 meters in some parts of the valley floor and at most 6 or 8 meters deep (Kirkby 1973), in contrast to the approximate 15-16 meters to groundwater in Santiago today (CONAGUA 2012). Before, farmers irrigated by drawing water from shallow wells with pails, in contrast to present-day techniques that involve pumps driven by gasoline or electrical power (ibid). Digging deeper wells, paying for electricity, and buying pumps have all increased the cost of infrastructure for growing cash crops. Perhaps in part for this reason, less than one-quarter of land engaged by the sampled migrant families was allocated to irrigated cash crops that generate work and income year-round. These cash crops included a variety of flowers, vegetables, herbs, and alfalfa. Flower types on land surveyed included cempasuchil (Aztec marigold), cristantemo (chrysanthemum), perrito (delphinium), flor de penumbra (English name unknown), cresta de gallo (Indian tursol), monte casino (heath aster) and nube (baby's breath). Vegetables and herbs included onions, cilantro and radishes. 
Table 4. Land Ownership and Use Among Migrant Households ( $\mathrm{N}=19$ except when otherwise noted). Land areas given in hectares.

\begin{tabular}{|l|l|l|l|l|}
\hline & Mean & Median & Lowest value & Highest value \\
\hline $\begin{array}{l}\text { Total owned area } \\
\text { (ha) }\end{array}$ & 2.4 & 1 & 0 & 14.5 \\
\hline Total owned plots & 5 & 3 & 0 & 23 \\
\hline $\begin{array}{l}\text { Area sharecropped } \\
\text { by households } \\
\text { who sharecrop } \\
\text { (ha) (N=5) }\end{array}$ & 1.3 & 0.7 & 0.05 & 3.3 \\
\hline $\begin{array}{l}\text { Area borrowed by } \\
\text { households who } \\
\text { farm borrowed } \\
\text { land (ha) (N=4) }\end{array}$ & .9 & .9 & 0.4 & 1.5 \\
\hline $\begin{array}{l}\text { Number of plots } \\
\text { owned, shared or } \\
\text { borrowed }\end{array}$ & 6 & 4 & 1 & 23 \\
\hline $\begin{array}{l}\text { Total owned, } \\
\text { shared or } \\
\text { borrowed area } \\
\text { (ha) }\end{array}$ & 2.9 & 1.6 & 0.25 & 14.5 \\
\hline $\begin{array}{l}\text { Area under maize } \\
\text { (ha) }\end{array}$ & 2.2 & 1 & $0 \%$ & 9.5 \\
\hline $\begin{array}{l}\text { Percent of all } \\
\text { surveyed lands } \\
\text { under maize }\end{array}$ & $74 \%$ & $82 \%$ & & \\
\hline
\end{tabular}

The households surveyed tended to fall into two groups which differed in their economic orientations: subsistence-oriented households and commercially-oriented households. Contrary to my beginning expectation that migrants would likely have gained enough capital in migration to reorient their household production strategies towards commercial rather than subsistence land uses, just three $(16 \%)$ of the sample migrant households produced maize primarily for commercial sale as grain. In these three commercially-oriented households, tortillas were purchased rather than produced at 
home. By contrast, sixteen of the twenty households surveyed (84\%) were subsistenceoriented households where the household produced maize for its own consumption and/or to contribute to the female householders' production of prepared foods for sale. Consumption of maize within the household ranged from direct human consumption of home-made tortillas to use of dry corn cobs as fuel and other purposes as part of the agricultural cycle. For example, both zacate and ugly maize kernels serve as animal feed, while dry maize stalks are mixed with animal dung as fertilizer.

Commercially-oriented households generally had substantially larger landholdings and fewer household members than subsistence-oriented households, and they were also the only households that owned tractors. Commercially-oriented households produced an average of 8.9 metric tons of maize in 2012, and their maize yields averaged 1.6 metric tons per hectare (Table 5). Subsistence-oriented households produced an average of 1.1 metric tons of dry maize grain in 2012, and their maize yields altogether averaged 1 metric ton per hectare, varying from the lowest level of harvest success at 0.04 tons per hectare to a high of 3 tons per hectare (ibid). Kirkby (1973) recorded varying maize yields in the Valley on a map that indicates that yields in the territory of Santiago ranged from 1.21 and 2 metric tons per hectare (Kirkby 1973, 66). This historical mean yield range is quite a bit higher than the mean yield of 1.0 tons per hectare calculated for the subsistence-oriented households in this survey, and more closely approximates the mean maize yield achieved by commercially-oriented households of 1.5 tons per hectare (Table 5). In general, maize yields from farming practices among the households surveyed herein appear diminished from historic levels. 
Addressing whether maize yields have declined throughout the Central Valley is beyond the scope of this research but worth future investigation.

Table 5. Maize Production Among Commercial and Subsistence-Oriented Migrant Households.

\section{Commercially-Oriented Households $(\mathrm{N}=3)$}

\begin{tabular}{|l|l|l|l|l|}
\hline & Mean & Median & Lowest value & Highest value \\
\hline $\begin{array}{l}\text { Dry Maize } \\
\text { Produced (Tons) }\end{array}$ & 8.9 & 6.5 & 6.3 & 14 \\
\hline Yield (Tons/Ha) & 1.6 & 1.5 & 1.5 & 1.7 \\
\hline
\end{tabular}

Subsistence-Oriented Households ( $\mathrm{N}=16)$

\begin{tabular}{|l|l|l|l|l|}
\hline $\begin{array}{l}\text { Dry Maize } \\
\text { Produced (Tons) }\end{array}$ & 1.1 & 1.0 & 0.04 & 3 \\
\hline Yield (Tons/Ha) & 1.0 & 0.9 & 0.4 & 2 \\
\hline
\end{tabular}

More specific details gathered on cropping and intercropping choices among the households surveyed reflect an orientation towards independent, household-level control over the means of future production, including planting of diverse maize varieties to optimize the chance of harvest in drought years. The majority of households ( $89 \%)$ used local, seed-saved maize varieties (termed criollo) and intercropped these with squash and/or beans (Table 6). With criollo varieties, in contrast to improved varieties, the grain doubles as seed for future plantings. Like the commercial producers, subsistence households planted mainly white and yellow criollo varieties, but also included some rows of red (referred to as rojo or nazareno), black (referred to as negrito or belatub) and multi-color (pinto) varieties, for seed-saving purposes. These varieties mature rapidly and can be planted as late as August. As such, they are a source of flexibility in the event of late-arriving summer rain. Many households sow just enough of these for seed. 
Maintenance of diverse maize stores is both a source of cultural pride and a measure for minimizing the losses associated with early growing season drought.

Table 6. Practices in Maize Production Among Migrant Households (N=19).

\begin{tabular}{|l|l|l|}
\hline & $\begin{array}{l}\text { Number of } \\
\text { Households }\end{array}$ & $\begin{array}{l}\text { Percent of } \\
\text { Households } \\
\text { Surveyed }\end{array}$ \\
\hline Plant local, seed-saved maize varieties & 18 & 95 \\
\hline Plant purchased, improved maize varieties & 2 & 11 \\
\hline Use tractor for ploughing & 19 & 100 \\
\hline Use oxen team in furrowing and planting & 3 & 16 \\
\hline Use draft horse in furrowing and planting & 8 & 42 \\
\hline Use tractor in furrowing and planting & 9 & 47 \\
\hline Use chemical fertilizer & 19 & 100 \\
\hline Intercrop maize with squash and/or beans & 17 & 89 \\
\hline Rely on family labor (children) & 13 & 68 \\
\hline Hire paid laborers & 14 & 74 \\
\hline Participate in labor exchange (guelaguetza) & 7 & 37 \\
\hline
\end{tabular}

Just two households planted purchased, improved maize varieties, although one of these was a commercial producer who also planted local varieties of maize. Hybrid varieties of corn are likely uncommon because they serve only as grain (not seed) and involve much higher associated costs of production due to initial purchase of seed, prescribed technology packages (some combination of fertilizers, herbicides and insecticides), and the irrigation requirement. In addition, a strong cultural preference for seed-saved maize was noted in many interviews and in participant observation.

Intercropping in Santiago involves sowing beans and/or squash and/or peanuts together with maize seeds to produce additional food and bring maize plants benefits from moisture-conserving leaves (e.g., squash) and nutrient-cycling roots (e.g., beans). Intercropping the milpa is a longstanding subsistence-oriented practice (Kirkby 1973). Almost all surveyed households intercropped rainfed maize with squash (Table 6). The 
two producers who did not intercrop were commercially-oriented producers using a tractor's sowing attachment, which has no capacity to measure and plant different seeds simultaneously. Anecdotally, households appear to intercrop beans less than in former times, although intercropping with squash remains almost ubiquitous. One informant explained that beans are labor-intensive to harvest and this may partially account for their reduced use.

\section{Costs and Revenues of Maize vs. Cash Crops}

A breakdown of the capital and labor investments required for irrigated crops and rainfed maize shows that producing maize is both less labor-intensive and less costly than market-oriented, irrigated crops. However, maize cultivation continues to require substantial numbers of labor days, and it tends to be less lucrative than cash crops when sold as grain. Participant observation and interviews among a subset of the 19 households surveyed enabled a detailed breakdown of costs and labors for maize and a sample cash crop flower, flor de penumbra.

A breakdown of the labor expenses of irrigated cash cropping, which is done year-round based on cycles of 2-3 months, depending on the crop, and rainfed maize, which is planted once per year, demonstrates the higher labor costs associated with cash crops (Table 7). 
Table 7. Comparative Labor Requirements for Well-Irrigated Cash Crops and DryFarmed Maize. Table format adapted from Kirkby 1973. Source: Field notes.

\begin{tabular}{|c|c|c|c|c|}
\hline & \multicolumn{4}{|c|}{ Individual Days of Labor } \\
\hline & \multirow{2}{*}{$\begin{array}{c}0.125 \\
\text { Hectare } \\
\text { Irrigated } \\
\text { Penumbra } \\
\text { Flower } \\
(2 \text { months })\end{array}$} & \multicolumn{3}{|c|}{$\begin{array}{c}1 \text { Hectare Dry-Farmed Maize } \\
\text { (5 months) }\end{array}$} \\
\hline & & $\begin{array}{c}\text { Ox- } \\
\text { Team/Horse/Tractor } \\
\text { Labor }\end{array}$ & $\begin{array}{l}\text { Additional } \\
\text { Labor }\end{array}$ & $\begin{array}{c}\text { Total } \\
\text { Labor } \\
\text { Required }\end{array}$ \\
\hline Field preparation & -- & .5 & -- & .5 \\
\hline Sowing/Transplanting & 5.5 & 1 & 2 & 3 \\
\hline Fertilizing/Fumigating & 3 & -- & 1 & 1 \\
\hline $\begin{array}{l}\text { Hilling up and } \\
\text { Weeding }\end{array}$ & -- & 1 & 1 & 2 \\
\hline $\begin{array}{l}\text { Irrigating during dry } \\
\text { season* }\end{array}$ & 6 & -- & -- & -- \\
\hline Harvest & 6 & -- & 12 & 12 \\
\hline Transport & 2 & 2.5 & 7.5 & 10 \\
\hline Tie zacate bundles & -- & -- & 3 & 3 \\
\hline Transport zacate & -- & 1.5 & 3 & 4.5 \\
\hline Total labor days & 22.5 & 6.5 & 29.5 & 36 \\
\hline Total days in period & 60 & $\rightarrow$ & $\rightarrow$ & 150 \\
\hline $\begin{array}{l}\text { Ratio labor days/ total } \\
\text { days }\end{array}$ & .375 & & & .24 \\
\hline
\end{tabular}

*Note: Based on irrigating every 2 days, labor time of 2 hours, and a full day calculated as 8 hours of work.

While maize is less-labor intensive than cash cropping, it still requires a significant output of labor that can be quite expensive. This is especially true for the households who do not count on the labor of the household head or of their adult children because they have migrated to the United States. When labor is fully monetized, the 
market value of maize sold as grain or seed rarely exceeds the costs associated with producing it, although there is potential to sell zacate as well to improve the profit margin (Table 8).

Table 8. Comparative Production Costs and Market Value of Harvest per Hectare. Amounts given in 2012 Mexican pesos (Exchange rate 12.5 pesos to the dollar.)

\begin{tabular}{|l|c|c|}
\hline & $\begin{array}{c}\text { Maize } \\
(1 \mathrm{ha}, 3-6 \text { month cycle })\end{array}$ & $\begin{array}{c}\text { Flor de Penumbra } \\
(.125 \text { ha, } 2 \text { month cycle })\end{array}$ \\
\hline Ploughings by tractor (2) & 1,250 & -- \\
\hline Seed cost & -- & 370 \\
\hline Inputs (Fertilizer) & 500 & $900^{1}$ \\
\hline Irrigation labor & -- & -- \\
\hline $\begin{array}{l}\text { Oxen or horse ploughing, } \\
\text { weeding, hilling up }\end{array}$ & 600 & 890 \\
\hline $\begin{array}{l}\text { Manual labor in sowing, } \\
\text { weeding }\end{array}$ & $600^{2}$ & $1120^{2}$ \\
\hline Manual labor in harvest & 2,250 & -- \\
\hline $\begin{array}{l}\text { Manual labor in zacate } \\
\text { harvest }\end{array}$ & $1,500^{2}$ & 3,480 \\
\hline $\begin{array}{l}\text { Total cost of production \& } \\
\text { harvest }\end{array}$ & 6,700 & $5,000-10,000$ \\
\hline $\begin{array}{l}\text { Potential revenue from } \\
\text { harvest }\end{array}$ & $3,300-7,700^{3}$ & -- \\
\hline $\begin{array}{l}\text { Potential revenue from } \\
\text { zacate harvest }\end{array}$ & $4,500^{4}$ & \\
\hline
\end{tabular}

1. Not including water charges if well is not owned, and gas/electricity for motorized pumps. 2. Not including the cost of providing breakfast and lunch for mozos, which always includes refresco or soda.

3. Price of local criollo maize ranges from 3 pesos/kilogram to 7 pesos/kilogram. Harvests are periodically lost and in this situation no gains are realized whatsoever.

4. At $\$ 5 \mathrm{MXN} /$ bundle. The hectare of corn produces about 900 bundles.

Several interviewed households described investing more capital in maize than what can be gained ("We almost don't break even"). Nevertheless, the use-value of cultivating maize is high, providing household members with food, fuel, feed for draft animals, and organic fertilizer. In addition, maize offers the basis for an array of risk- 
averse activities that straddle subsistence and commercial activity, including raising household animals for sale and producing maize-based foods for sale.

\section{Labor and Technology}

Labor sources for agricultural production among the sampled migrant households in this study included family labor, friends or relatives exchanging labor through guelaguetza reciprocity, paid mozo labor, or, most often, combinations of these labor sources (Table 6). Among households surveyed, guelaguetza labor is less common than hiring mozos at the going rate of 150 pesos per day (approximately $\$ 11$ USD) or 80 pesos per half-day (approximately \$6 USD). Still, seven of the households surveyed (37\%) reported participating in guelaguetza labor exchange. Fourteen households (74\%) hired mozo labor, while 13 households (68\%) relied in some part on their children's labor. While quantifying agricultural labor for different tasks throughout the year was beyond the scope of this study, it is worth noting that children's labor availability is constrained by school attendance (see Chapter 3). Household labor for agriculture also tends to be constrained due to the established networks that facilitate migration by the second generation of adult migrants (Table 3). The households surveyed used various labor strategies simultaneously, which accounts for the fact that the number of households involved in each of these labor strategies do not add up to the total number of surveyed households (Table 6).

Labor scarcity, capital constraints, time-space compression, and the quality of results achieved with beasts of burden appear to govern the diverse technology choices in maize farming activities observed. Time-space compression can be noted in practices that 
have transformed to cover more ground in a shorter period of time and to save costs through labor-saving ingenuities. Changes in technology encompass both mechanizations as well as non-industrial shifts in techniques of harvest. Ploughing and harrowing, where necessary, is now ubiquitously performed by tractor. However, opening furrows and sowing continues to follow traditional methods, with some modifications. The traditional sowing technique is to use an ox-drawn plough or yunta to open furrows, into which maize seeds are immediately sown by foot. Three of the sampled households $(16 \%)$ reported sowing maize by this traditional method. Eight (42\%) sowed by the same footplanting method but used a horse-drawn plough to create furrows, and nine (47\%) used a tractor to create furrows for planting by foot or with the tractor's planter apparatus. One household hired a tractor on one of their plots, and used a horse-drawn plough on another; their practices are counted in both of these technology choices (Table 6).

Valley maize-farming practices in the late 1960s involved ploughing the field by ox-team and wooden plough, using the ox-plough to create furrows, and planting by using one's feet to push earth over a small handful of seed tossed every two steps (Kirkby 1973). Two cost-saving transformations have occurred since then, as observed in the survey. First, the oxen-powered plough has been surpassed by a combination of horsedriven ploughs and tractors. Second, non-mechanized changes in harvesting techniques make the harvesting process less arduous, possibly reflecting an adaptation to the scarcity and higher cost of labor.

Most commonly, cultivators today hire tractors by the half-hour for ploughing and harrowing services and use or hire a horse-driven plough to carve furrows into the 
ploughed field. Informants cited the ability of a horse to plough all day and plough at a faster pace than the yunta as reasons for the increased popularity of horse ploughs. As one, age 45, explained: "People say that the yunta walks too slow. The horse is faster, and it works all day. The bulls only work a half-day." The horse is also a cost-saving choice. A workhorse costs approximately $\$ 3,000$ to $\$ 4,000 \mathrm{MXN}$, while a pair of mature, workready oxen costs $\$ 20-\$ 25,000 \mathrm{MXN}$ (and the two oxen eat twice as much as the single horse). Furrowing by horse thus demands less monetary investment. Returns in the form of oxen dung as organic fertilizer are made up for in the increased use of chemical fertilizer and the common practice of raising young bulls, sheep and goats for slaughter or sale and for the organic fertilizer these provide.

In contrast with 50 years ago, tractors are now a ubiquitous technology choice for ploughing and harrowing, although they have not yet surpassed wooden ploughs for furrowing and planting processes. Kirkby (1973) noted that there was limited use of tractors from 1967-1970; tractors were scarce and had to be hired by the day. Because individual parcels were so small, it did not appeal to farmers to pay a full day's ploughing for an hour-long tractor pass (Kirkby 1973, 74). Today, tractors can be hired by the halfhour, and tractors-for-hire are no longer scarce in the high season because an estimated 30 tractors within the community can be contracted for ploughing and harrowing. They are also contracted for furrowing at prices that compete with the costs of ox-drawn furrowing services, although wooden ploughs pulled by oxen or horse are generally considered to produce superior furrows. Tractors appear to be the sole reason that the three commercial producers surveyed herein are able to make profit, as they have 
invested in their machinery to almost completely remove hired labor costs, using both sower and harvester attachments on their tractors. For those who harvest with a tractor's harvesting mechanism, the labor is significantly diminished. But for the majority who do not, the labor costs of production remain high.

A distinct labor-saving technological shift has also taken place in harvesting. Approximately 15 to 20 years ago, laborers still harvested their mazorca, or dry ears of corn, by plucking it off the standing, dry stalk and tossing it into a basket tied to their heads. This was difficult work as the large baskets became heavy. It is still practiced in neighboring communities. However, in Santiago today, the most common harvesting practice is to cut the maize stalks at their base, pluck the mazorca from them, then toss it into the nearby basket. This rolls what used to be two labor-intensive harvesting stages into one, because the zacate was always cut for animal fodder following harvest of the mazorca. Collecting the mazorca from the felled stalks and placing it in a basket on the ground rather than in a basket on one's back significantly reduces the labor expense of harvest. In addition, many report that they lose fewer leaves to the wind this way, thus maximizing the zacate that can be bundled and carted or trucked home following harvest.

\section{Uses of Maize Harvest}

Rearticulating the definition of "subsistence-oriented" appears necessary in light of the mixed uses for maize among the 16 households who do not produce maize for sale as grain. With an average household size of 5.5 persons and an average annual production of 1.1 tons of maize, the subsistence-oriented households generate 200 kilograms of maize per capita per year. Hypothetically, this amounts to over half a kilogram of maize 
per person per day (about five tlayudas). Household production would thus appear as oriented to the subsistence goals observed among cultivators in the region 50 years ago (Kirkby 1973).

However, not all maize is consumed by household members. Because several households use maize as the basis of various foods prepared for sale, the amount directly consumed by the household is lower. Tortilla-producing households also buy several months' worth of commercial grain. Maize stores reportedly lasted in the home for a range of 1 to 12 months and an average of 8 months. Uses of maize among subsistenceoriented households thus reflect market destinations of the harvest as prepared foods for sale, in addition to direct household consumption.

Fifteen households produced tortillas for household consumption while four households consumed purchased tortillas (Table 9). In two of these households, however, tortillas were purchased because the women who would otherwise make tortillas for the home were occupied with full-time production of tamales and roasted chickens, both of which are maize-dependent activities. Six out of the 19 households (26\%) produced maize-based foods for sale. Four sold tortillas (tlayudas) while one sold tamales and another sold maize-fed, roasted chickens. Therefore, maize uses go beyond direct household demands for subsistence grain to manufacturing of prepared foods based on this same subsistence production activity. 
Table 9. Maize Use in Migrant Households ( $\mathrm{N}=19)$.

\begin{tabular}{|l|l|l|}
\hline Household Maize Consumption & $\begin{array}{l}\text { Number of } \\
\text { Households }\end{array}$ & $\begin{array}{l}\text { Percent of } \\
\text { Households }\end{array}$ \\
\hline Prepares tortillas for household consumption & 15 & 79 \\
\hline $\begin{array}{l}\text { Prepares maize-based foods for sale (tortillas, } \\
\text { atole, tamales, roasted chickens) }\end{array}$ & 6 & 32 \\
\hline
\end{tabular}

Household maize production may in some cases relate directly to capital income strategies that rest on women's livelihoods selling maize-based foods. Women's incomes from tortilla sales offer a net daily value of up to $\$ 135 \mathrm{MXN}$ per day while also guaranteeing tortillas for household members' consumption (Table 10). When using home-grown maize rather than purchased maize, the profit from tortilla sales increases. Table 10. Breakdown of Costs and Earnings in Daily Household Tortilla Sales. Capital investment and earnings in Mexican pesos. Source: Field notes.

\begin{tabular}{|l|l|l|}
\hline \multicolumn{2}{|c|}{ Daily production goal: 115 tortillas (100 for sale, 15 for home use) } \\
\hline & Daily costs/earnings from tortillas in \$MN when maize is: \\
\hline & purchased & produced \\
\hline Price/10 kilos maize & $25-70$ & -- \\
\hline Price of firewood & 40 & 35 \\
\hline Price of milling & 20 & 20 \\
\hline Travel to city & 10 & 10 \\
\hline Total cost & $95-140$ & 65 \\
\hline Earnings from 100 sold & +200 & +200 \\
\hline Net daily value & $+60-105$ & +135 \\
\hline
\end{tabular}

While the cottage economy of women producing tortillas and other maize-based foods for sale straddles subsistence and commercial activity, earnings from tortilla sales compares favorably with other livelihood strategies common among (male) migrants in the households surveyed. A tortillera's sample daily earnings from sales when maize does not have to be purchased ( $\$ 135 \mathrm{MXN}$ ) closely approximates the salaries of her male counterpart, who may work as a field laborer or taxi driver at \$150 MXN per day, or as a 
policeman for \$145 MXN per day (Table 11). In the context of periodic migrations of male household heads with uncertain remittance outcomes, the income provided by tortilla production for sale may be extremely important.

Table 11. Comparative Livelihoods: Tortillera, Field Laborer, Taxi Driver and Policeman. Capital investment and earnings in Mexican pesos. Source: Field notes.

\begin{tabular}{|l|l|l|l|l|l|}
\hline & $\begin{array}{l}\text { Labor } \\
(\mathrm{hrs} / \text { day })\end{array}$ & $\begin{array}{l}\text { Capital } \\
\text { Investment } \\
(\$ \mathrm{MXN})\end{array}$ & $\begin{array}{l}\text { Earnings } \\
(\$ \mathrm{MXN})\end{array}$ & $\begin{array}{l}\text { Net gain } \\
(\$ \mathrm{MXN})\end{array}$ & Benefits \\
\hline Tortillera & 12 & $65-140$ & 200 & $60-135$ & Food, animal fodder \\
\hline Field Laborer & 12 & -- & 150 & $150+$ & Meals included \\
\hline Taxi Driver & 14 & -- & 150 & 150 & Non-physical labor \\
\hline Policeman & 12 & -- & 143 & 143 & Non-physical labor \\
\hline
\end{tabular}

Benefits of the tortillera livelihood include feeding the household while also generating capital through selling maize as a value-added commodity. Calculations from data provided by interviews and participant observation among tortilleras indicate that one kilogram of maize produces 12.5 large tlayuda tortillas (115 tortillas may be produced in a day with 10 kilograms of maize) (Table 10). Tlayudas are sold at 2 pesos apiece. The revenue from one kilogram of maize elaborated into tortillas is thus 25 pesos per kilogram, an almost tenfold increase in value over the harvest season grain price of 2.5 pesos/kilogram. The revenues made possible from tortilla sales thus indicate a potentially profitable, commercial outcome of household agricultural orientations. Future research would benefit from analysis of whether tortilla production for sale may also reflect increased regional demand for tortillas due to increased urbanization in the Valley of Oaxaca (INEGI 2013) (Tables 1 and 12). 


\begin{abstract}
$* * * * *$
Results of this household survey and supplemental data from participant observation indicate that that migration has not modified the longstanding, regional household orientation in agriculture towards local, seed saved maize varieties observed prior to widespread migration activity. Households with migrant heads continue to orient a larger proportion of land resources to maize production than to cash crops, producing an average one ton of maize per year, as they did in the late 1960s (Kirkby 1973). In most households, this production is destined for subsistence purposes as well as value-added preparations of maize into foods for sale.
\end{abstract}

Households have adapted to labor scarcity and the increasing rigors of economic integration with technological change, including increased use of tractors and chemical fertilizer, yet a majority use traditional sowing methods. Traditional institutions of labor reciprocity and family labor remain important, although available laborers are fewer where adult children currently live and work abroad, or where children are enrolled in school full-time, which is the case in most households. Capital constraints may reinforce a risk-averse farming orientation, while labor constraints and time-space compression may impel technological change.

I now turn to results that enable an informed speculation on why migration has not led participating households away from traditional agricultural practices centered on producing minimum quantities of rainfed maize. Results from triangulated analysis of data representing landscape-level phenomena suggest that migration and groundwater scarcity may be reinforcing continuity in agricultural practices. 


\section{Chapter Five: Possible Drivers of Agricultural Change and Continuity}

In this chapter, I triangulate analyses of data from surveys, participant observation, interviews and archival research to explore how migration and changes in the physical environment over the past 50 years may have modified Santiago's agricultural landscape in ways that reinforce continuity in subsistence agricultural practices. Current land and labor relations form a useful point of entry for considering the impact of migration on Santiago's agricultural economy, and in relating migrant household practices to the broader evolution of agriculture in the community. Possible drivers of change in land and labor relations include migration, which encompasses cultural and economic shifts, and changes in water resources, which implicate government policy, material cultural transformations, and potentially, global climate change.

Data from participant observation, archival research, interviews, and supplemental surveys presented and analyzed herein suggest several possible factors of change in land and labor relations relevant to interpreting the apparent continuity observed in migrant households' agricultural practices. First, wage labor scarcity in Santiago may be the result not simply of the demographic change produced by absentee migrants of working age, but cultural diffusion of changing expectations around work among return migrants and non-migrants in the community. Second, biophysical data and perceptions voiced by residents of Santiago regarding local climate changes suggest water table drawdown may have influenced agricultural land suitable for maize versus 
irrigated crops, and may also (anecdotally) be linked to migration decisions. Finally, the terms of longstanding practices of sharecropping in the community may offer a cipher for analyzing changing relations of land and labor in the context of migration and biophysical change. In this chapter, I present analyses of these distinct data sources independently and then interpret them in triangulation with each other and results from Chapter Four in order to speculate upon the potential broader forces driving the apparent continuity in household-level agricultural practices.

\section{Impacts of Migration on Labor}

Migration may be impacting land and labor relations in Santiago by creating wage labor scarcity through changing expectations of work and remuneration. The demographic loss of able-bodied workers to wage labor abroad is an uncontroversial driver of labor scarcity in migrant-sending towns in Mexico and elsewhere (see Jokisch 2002, 525-527 for a comprehensive review). However, an additional possibility emerged from participant observation, interviews and archival research, which is that cultural effects of return migration and other processes that have increased economic integration with the urbanized world may also work to erode the supply of agricultural wage workers in a migrant-sending town, with consequences for land-labor relations.

Perhaps due to the unequal distribution of lands in Santiago in the postRevolutionary period (see Chapter Three), wage farmwork was allegedly very poorly paid for most of the $20^{\text {th }}$ century. Oral histories, archival data and interviews suggest that mozos, the local term for wage laborers, came from a local underclass of poorer community members lacking recourse to their own farmland. Traditionally, and to this 
day, a day's agricultural work included two meals as well as wages. In this way, agricultural wage labor served as a lifeline for the poor, in service of families who had attained some level of capital accumulation. An alternative option was to sharecrop, but this required ownership of some fixed means of production (e.g., a yunta, children to help with farmwork), or the capital to engage it.

According to oral histories and interviews, the benefits of local wage labor have shifted with migration. While historically, meals allegedly consisted of mere tortillas, salt and chile, today a wage laborer can expect a hot meal that includes meat as well as soda to drink. A day laborer's salary has also doubled since 1999. The smaller pool of local laborers caused by some working abroad as migrants has likely shifted the bargaining power of laborers, through basic macroeconomic principles of supply and demand. But in addition, new demands likely reflect the higher wages and less strenuous work that characterize janitorial services in Mexico City or dishwashing in Los Angeles in comparison with local agricultural wage work. Several return migrants that I spoke with voiced this perception. Possibly as a result of their experiences outside of the community, migrants returning to Santiago seek to avoid working as agricultural wage laborers outside of kinship or compadrazgo relationships.

The experiences and expectations of migrants may also influence non-migrants in the community, generating increased community-wide scarcity of local agricultural wage labor. Several landowners surveyed mentioned that wage laborers must be hired from outside of the community because young men from the community are no longer willing to work as agricultural day laborers. It therefore seems possible that migrants' rejection 
of local wage labor may have affected perceptions of work and standards of material wealth among young men throughout the community in a process of cultural diffusion. The "relative deprivation" hypothesis in migration theory helps to explain this process:

People engage quite regularly in interpersonal income comparisons within their reference group. These comparisons generate psychic costs or benefits, feelings of relative deprivation or relative satisfaction. A person may migrate from one location to another to change his relative position in the same reference group, or to change his reference group.... Moreover, a reference group characterized by more income inequality is likely to generate more relative deprivation and higher propensities to migrate. Note also that as particular individuals migrate, the relative deprivation perceived by nonmigrants may change, thereby creating second-round inducements to migrate. (Stark and Bloom 1985: 173-4)

The cultural impact of return migrants who have new expectations with respect to agricultural labor may induce a sensation of relative deprivation among other members of the community. Rather than solely inducing future migrations, however, I would suggest that relative deprivation can also impact perceptions of acceptable, local work options among local working-age men. Several of those I interviewed and shared experiences with described agricultural wage labor as exhausting and poorly paid, even though agricultural wages have increased and meals offered today are rich and filling.

The commercial producers who depend on a relatively consistent, paid labor force hire mozos from communities outside of Santiago, where young men are still willing to engage in hard, physical agricultural labor for wages that are low in comparison with those available in urbanized professions and from manual labor in the United States. Yet workers from other towns are not easy to secure. As migrants, they tend to work in Santiago for a limited period, and have the ultimate goal of returning to their own communities. Those who contract them complained that there is substantial turnover. 
Regardless, it is important to note that any cultural process that may diminish local agricultural wage labor does not appear to prevent Santiago's young men, many of whom are return migrants, from wanting to work the land as independent cultivators and contractors. Rather, they carry out agricultural labor in alternative social/economic forms, either as children of the household head (with strong social obligations to their parents and potential to inherit landholdings), or as owners of their own land and/or labor. Thus, a key observation is that willingness to perform waged day labor, which is required by most commercially-oriented producers, may be limited by cultural processes of migration and return migration, while those with aptitude/need for agricultural work may be selfdirecting to sharecropping arrangements, analyzed later in this chapter.

\section{Impacts of Changing Water Resources on Agricultural Land and Migration}

Over the past forty years, groundwater resources in the Valley of Oaxaca have diminished despite the fact that total precipitation in the region appears to be increasing (CONAGUA 2001, 2012) (Figures 5a and 5b). Modernized agricultural projects begun in the 1970s and urban expansion have demanded groundwater at rates that vastly exceed the recharges brought by rainfall, affecting water availability for direct human consumption and for irrigated crops. These biophysical changes may partially explain both rainfed maize agriculture and migration in Santiago.

Climate data obtained from stations near Santiago for the past 50 years, while incomplete, suggest that agricultural drought has been a problem in recent decades. Perceptions gathered during fieldwork regarding changes in the local climate provide insight into how biophysical changes may be influencing agricultural decisions. These 
support the tentative explanation that groundwater scarcity has reinforced dry-farmed maize as a risk-averse crop. Migration decisions may also relate to the increased costs of accessing groundwater from a much-diminished aquifer.

\section{Changes in the Valley Aquifer}

The Valley of Oaxaca rests on an aquifer of varying depths that historically lies 1-3 meters beneath the ground surface (Kirkby 1973, CONAGUA 2001). Groundwater loss has resulted from agricultural projects involving heavy pumping instituted by the state government in the 1970s. In San Antonino Castillo Velasco, which borders the municipality of Santiago Apóstol to the northeast and is the "heaviest area of agricultural pumping in the Valley," the water table dropped "from 4 meters to anywhere from 12 to 30 meters" by the early 1990s (Dilley 1993, 221). Groundwater levels in the Ocotlán district, which encompasses Santiago Apóstol, descended from 2 meters below the surface in 1968 to between 8 and 10 meters in 1985 (Dilley 1993, 222). Finally, in fields where flowers were grown, the water table dropped from 12 meters in 1985 to 25 meters in 1991 (ibid). According to the state water agency, the groundwater levels measured in Santiago in 2001 were 5-6 meters below the surface, and had dropped to 15-16 meters by 2011 (CONAGUA 2012). The engineer in charge of provisioning municipal water stated that the water table in the low zone is 15 meters down, and in the high zone (towards San Sebastian), 22 meters. This has made traditional pot-irrigation techniques with multiple wells per field impracticable.

In addition to agricultural pumping, expansion of Oaxaca City and urbanization of satellite towns have involved increased groundwater exploitation, along with new levels 
of stream and river pollution. A 2001 study commissioned by Oaxaca's state water agency (Comisión Nacional del Agua, Cuenca Pacífico Sur) states that public urban water use is every day more difficult to satisfy for a population of 732,448 inhabitants that is growing at an annual rate of $4.74 \%$, especially due to inefficient municipal infrastructure and contamination of above-ground water by untreated, urban effluent (CONAGUA 2001). The population of the capital city of Oaxaca de Juárez increased more than three-fold between 1960 and 1995 (Table 12).

Table 12. Population Growth in the State Capital of Oaxaca de Juárez (Oaxaca City) and in the State of Oaxaca, 1960 to 2010. Source: INEGI 2013.

\begin{tabular}{|l|l|l|l|l|}
\hline Year & Pop. Oaxaca City & (\% increase) & Pop. Oaxaca & (\% increase) \\
\hline 2010 & 255,029 & $-1.2^{*}$ & $3,801,962$ & 8.4 \\
\hline 2005 & 258,008 & 2.4 & $3,506,821$ & 2.0 \\
\hline 2000 & 251,846 & 4.0 & $3,438,765$ & 6.5 \\
\hline 1995 & 242,247 & 13.8 & $3,228,895$ & 6.9 \\
\hline 1990 & 212,818 & 38.0 & $3,019,560$ & 27.5 \\
\hline 1980 & $\begin{array}{l}154,223 \text { (living in } \\
\text { location with greater } \\
\text { than 100,000 } \\
\text { inhabitants) }\end{array}$ & 54.9 & $2,369,076$ & 17.5 \\
\hline 1970 & $\begin{array}{l}99,535 \text { (living in } \\
\text { location with greater } \\
\text { than 100,000 } \\
\text { inhabitants) }\end{array}$ & 37.5 & $2,015,424$ & 16.7 \\
\hline 1960 & 72,370 & & $1,727,266$ & \\
\hline
\end{tabular}

*Apparent population decrease may be due to changing administrative boundaries.

Changes in groundwater form a central driver of land use and socioeconomic change, as access to water becomes increasingly dependent upon having the capital resources necessary to dig ever deeper wells for irrigating cash crops. In addition, maize yields have likely suffered from decreased soil moisture associated with groundwater loss. Such changes in the environment may be drivers of agricultural continuity in 
migrant households that continue to allocate land resources to dry-farmed maize - as well as reasons to migrate in the first place, discussed later in this chapter.

\section{Inter-annual Precipitation, Maximum Temperature, and Evapotranspiration Records, 1962-2012}

As maize is a rainfed crop, changes in the local climate in Santiago stand to form potentially significant influences on household-level agricultural practices historically devoted to maize. Previous research established that rainfall is far more important than any other variable on the productivity of maize in the Valley of Oaxaca (Kirkby 1973, Dilley 1993). Maize growth depends upon a precarious minimum balance of rainfall that barely exceeds evapotranspiration during the summer months. Where it does not, the maize crop is lost. In this section, I analyze and discuss precipitation, daily maximum temperature, and evapotranspiration records from the two climate stations nearest to Santiago for the 50-year period from 1962 to the present. Only records from the rainy season spanning April to October are discussed, since these are the months in which the climate impacts maize agriculture, and since precipitation in the months of November to March is negligible (Figures $4 a$ and $4 b$ ).

Problems in the data deserve discussion. National Meteorological Service data from the climate stations four kilometers east (Ocotlán de Morelos) and four kilometers west (San Pablo Huixtepec) of Santiago Apóstol are each riddled with gaps that preclude conclusive inter-annual analysis. Relatively complete data from the Oaxaca de Juárez climate station 30 kilometers north of Santiago (Figures 5a and 5b) poorly reflects the local climate in Santiago, due to the topography of the Valley (Figure 1). Thus, to make inter-annual analysis possible, I combined data from the two stations within four 
kilometers of Santiago. This filled in some but not all of the gaps in the datasets. Gaps and other potential problems in the data are discussed here, along with findings.

The record of precipitation in the growing season of April to October, which includes data for 38 of the 50 years from 1962 to 2012, reveals no obvious trends towards diminishing or increasing precipitation (Figure 6).

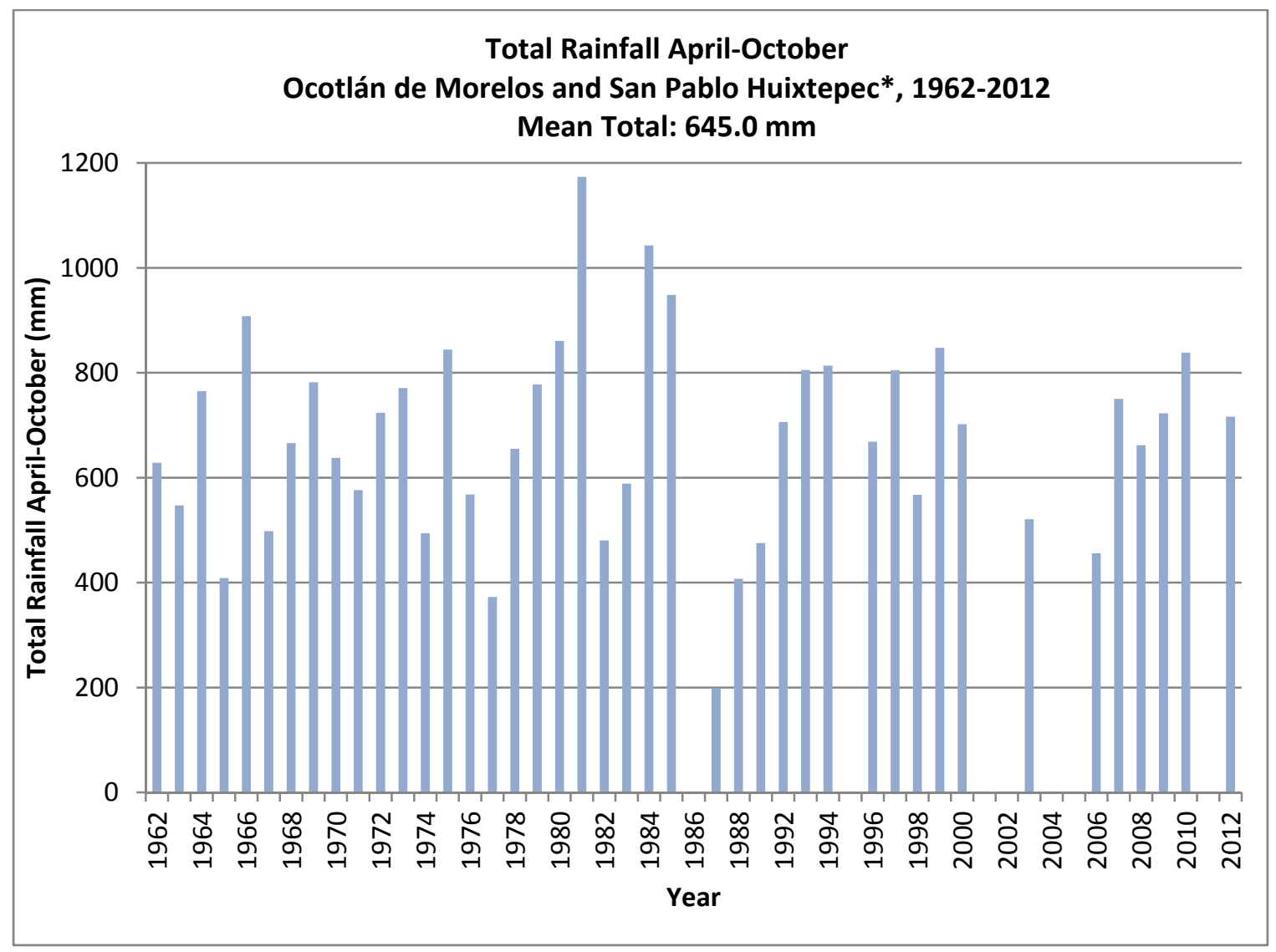

Figure 6. April to September Precipitation in Ocotlán de Morelos (1962-2000) and San Pablo Huixtepec (2003-2012). Source: CONAGUA 2013. Note: Zero values reflect missing data.

However, it does shows substantial inter-annual variability. Several potential flood years with abnormally high levels of precipitation appear in the 1980s, especially 1981 and 1984. In comparison, 1977 and 1987 were the most severe meteorological drought years recorded. An overall trend of increased or decreased precipitation, such as that found 
from long-term and more complete data from Oaxaca de Juárez (see Figures 5a and b), is not apparent.

The record of daily maximum temperatures indicates perplexing variability in the 50 years of this study (Figure 7). The record generated for 38 of the 50 years from 1962 to 2012 shows high daily maximum temperatures in 1962 that drop precipitously in the late 1960 s, then rise just as steeply as they dropped to remain relatively high throughout the 1970s. The cold spell in the period 1962-1969 may reflect errors in the data as this trend is not reflected in the precipitation record (Figure 6). Daily maximum temperatures appear to decrease slightly in the early 1980s. Subsequently, several years of incomplete temperature records (1989-1991 and 2001-2005) hamper analysis of long-term trends.

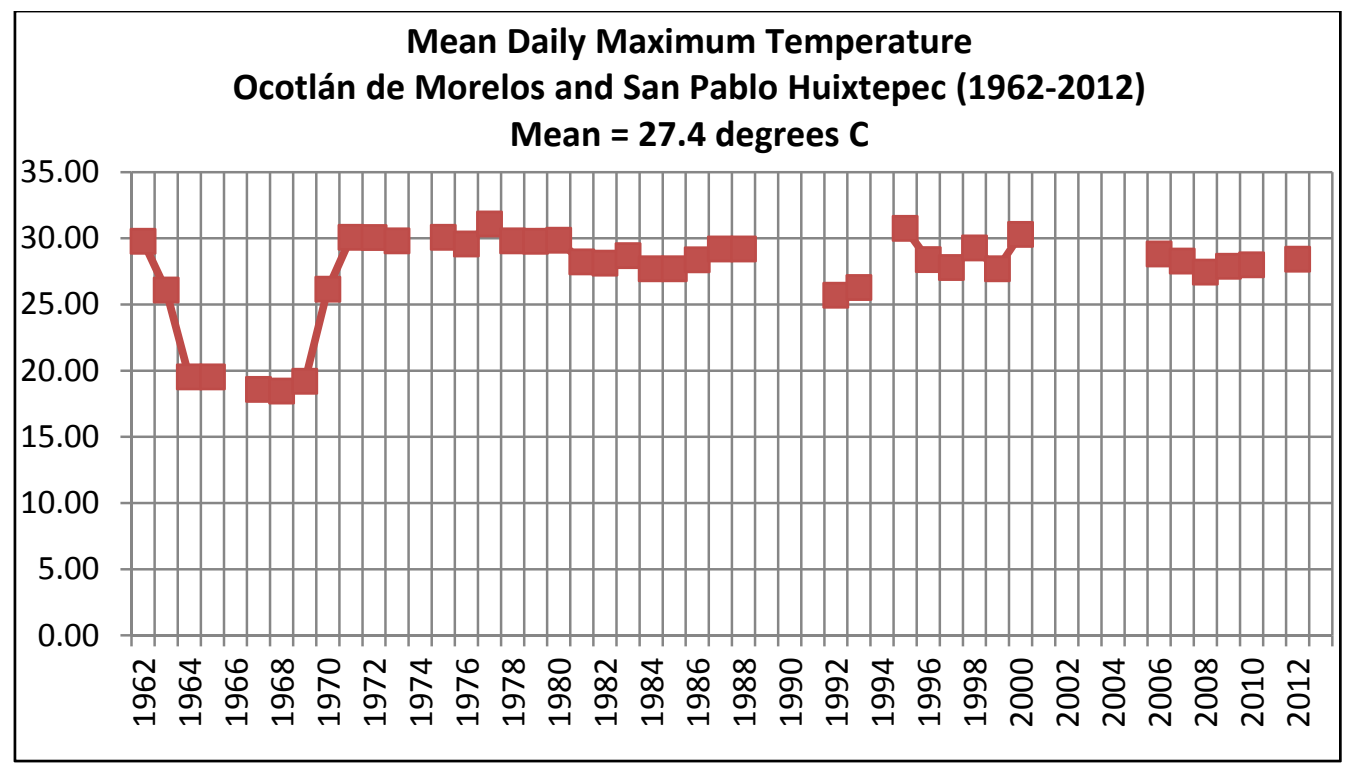

Figure 7. Historical mean daily maximum temperatures in Ocotlán de Morelos (19621984) and San Pablo Huixtepec (1985-2012). Years with overlapping data (averaged): 1985, 1987, 1996 and 1998. Source: CONAGUA 2013.

Based on this incomplete record, the yearly averages of daily maximum temperatures have increased since the 1960s, yet not consistently nor evenly. Looking 
further back beyond a gap in records from 1936 to 1962, an almost complete record of daily maximum temperatures from 1923 to 1936 (not displayed) reveals a daily maximum temperature mean of 27.2 degrees Celsius. This is just two-tenths of a degree lower than the average from 1962 to 2012, and suggests little long-term change. However, the anomalous cold spell that appears in the data from 1964 to 1969 skews the evidence otherwise pointing to a possible warming trend. The mean daily maximum temperature from 1970 to 2012 is 28.7 degrees Celsius, 1.5 degrees higher than the average from 1923 to 1936 . This suggests that a general warming trend over the $20^{\text {th }}$ century may have taken place.

Gaps in the data on precipitation and temperature preclude conclusive findings of the presence or absence of long-term changes in the local climate. However, there is evidence that regular agricultural droughts have affected maize harvests in Santiago in recent decades. A partial record of daily precipitation and evapotranspiration averages from the climate station in San Pablo Huixtepec four kilometers west of Santiago reveal a precarious water balance for rainfed agriculture (Figure 8). Complete records of evapotranspiration and rainfall in the growing season months were available for 14 years of the 28 year period spanning 1984 to 2012 . In this period, daily evaporation between April and October averaged $5.9 \mathrm{~mm}$, and daily rainfall averaged $7.0 \mathrm{~mm}$. Agricultural drought is evident in the years spanning 1984 to 1987, as well as in 1998, 2003 and 2006. 


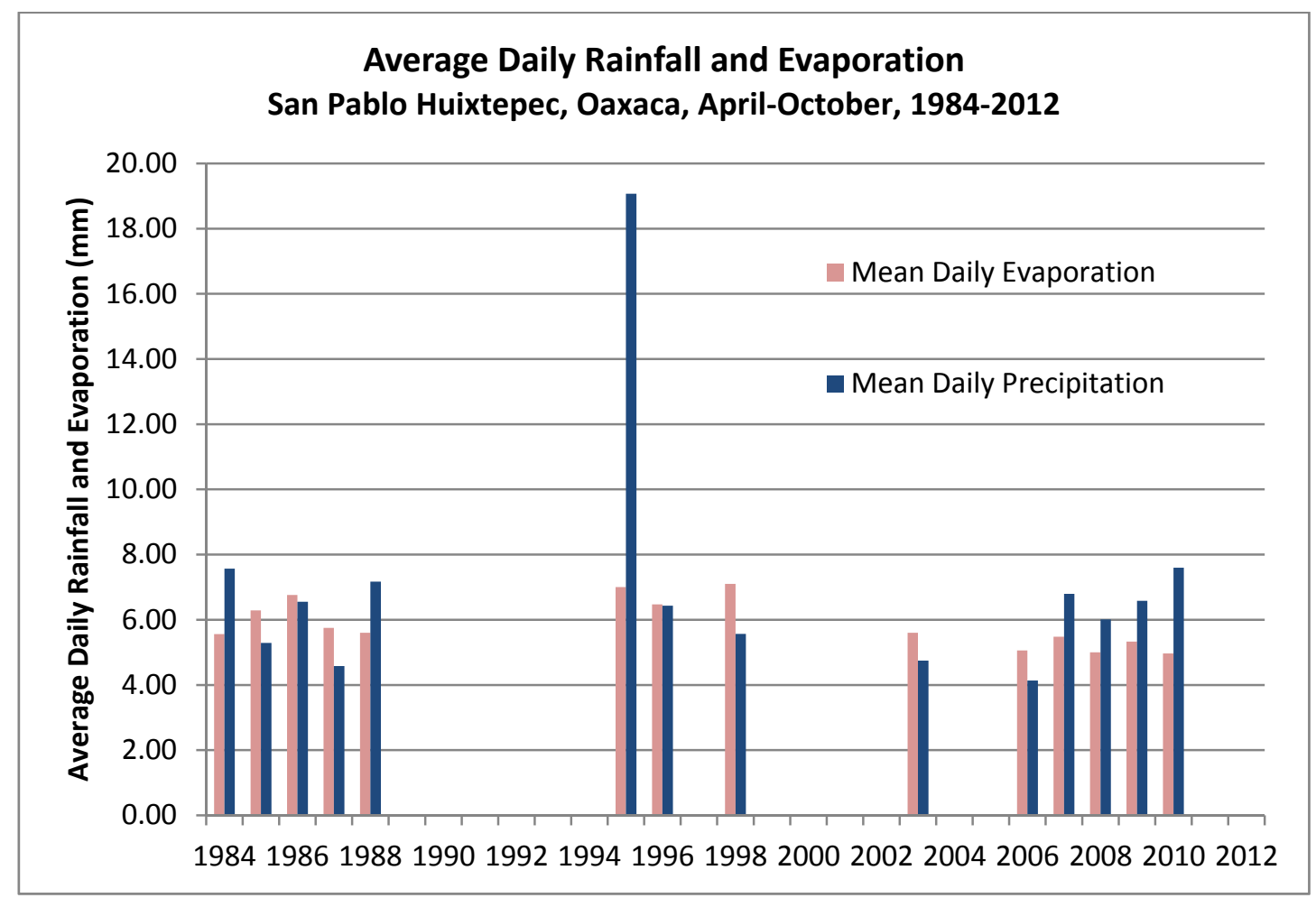

Figure 8. Average Daily Precipitation and Evaporation in San Pablo Huixtepec, 19842012. Source: CONAGUA 2013. Note: Zero values reflect missing data.

Climate records of precipitation, maximum daily temperature, and evapotranspiration during the growing season do not paint a conclusive picture regarding overall changes in climate over the past 50 years. However, they do reinforce the known fact that rainfed agriculture in this region is subject to agricultural drought and flooding events that can wipe out a given year's maize crop. Moreover, long-term changes in temperature and precipitation appear in the records from Oaxaca City (Figures 5a and $5 b$ ), and should be considered a potential factor in individuals' perceptions of environmental change, discussed below, due to the close ties between Santiago and the capital city. 


\section{Residents' Perceptions of Environmental Change}

Perceptions of environmental change open a useful window onto the entwined social and biophysical forces in the landscape that may be influencing continuity in agricultural practices and, anecdotally, migration decisions. Perceptions of water scarcity attributed to decreased precipitation and increased temperatures may reflect a regional problem of aquifer drawdown that has impacted agricultural livelihoods. Local residents relate water scarcity and increased temperatures to changes in Santiago's local built environment and material culture, some of which implicate the socio-cultural impacts of return migration and migrant capital.

Twenty of the 23 residents I surveyed regarding whether the local climate had changed stated they perceived a general shift. They agreed upon the nature of this shift, describing diminished water availability for agriculture and higher temperatures. Those citing diminished moisture generally referenced the period spanning 1970-1985, while increasing temperatures were attributed more frequently to the 1990s and, especially, the year 2000. A small handful of individuals suggested that within the past three years there has been an increase in rainfall along with hotter temperatures.

The following statements demonstrate the perceived changes:

"I remember when I was a little girl, we didn't have pavement in the house, and I used to sit listening to my parents talk and dig my toes into the ground. I would scrape with my toes and soon there would be water in the place where I had dug. The water was that close to the surface." (Mariana, age 47)

"There used to be water just one meter below the surface, and so you would plant your corn carefully with a stick (coa) to take advantage of that humidity." (Iván, age 78) 
"It used to rain good, heavy rains. Now it rains, but in showers. It's not the same." (César, age 50)

"In about 1970, everything began changing. It began getting hotter little by little. When the sun was overhead, it was hotter. We used to work all day, and we felt the heat but not that bad. Now, we take a break in the middle of the day when it gets so hot." (Andrés, 67) ${ }^{5}$

While seven of the 20 respondents who affirmed local climate changes professed to have no theories regarding their causes, the remaining 13 had ideas about the regional processes that contributed to decreased water availability and the perception of hotter temperatures. Respondents offered a number of different reasons for these climatic shifts, and after several individuals had voiced them these became a classification scheme by which to characterize subsequent responses.

Reasons for the perceived climatic changes included: deforestation; increased water use and waste through modern homes and new agricultural technologies; pollution caused by plastics burned as waste; increased runoff from urbanization of the built environment; increased use of "hot" things (including agrochemicals, gasoline and plastics); and a historically-significant 1978 stream alteration (a likely source of accelerated groundwater depletion and/or decreased rate of recharge). In some cases, an individual brought up multiple causes and I recorded these as separate perceptions according to their referenced historical moment. I recorded a total of 30 perceptions. Several perceptions pointed to the increased construction projects funded by absentee or return migrants, which are generally built in impermeable materials and can involve deforestation of street-side or patio trees and foliage.

\footnotetext{
${ }^{5}$ Names have been changed.
} 
Comparing these local perceptions with the available data on temperature and precipitation yielded inconclusive results. However, local perceptions of dryness do correspond with actual recorded decreases in groundwater availability. In contrast with climate data, there is overwhelming evidence that the aquifer drawdown constitutes a significant change in the productive possibilities of Santiago's land, given environmental limits and limits to capital accumulation required for digging ever deeper wells.

Real groundwater scarcity and perceptions of environmental change may be two related factors in migration decisions, along with their obvious implications for agricultural land use. Anecdotal evidence suggests that scarcity of groundwater in the community can drive decisions to migrate. On my first day of fieldwork, Santiago’s municipal president handed me a 25-page story he had written, bearing the title, "Why Did the Well Have to Dry?” (“¿Por qué se tuvo que secar el pozo?”) The tale follows a young child growing up in Santiago in the early 1990s who delights in his farming duties and eagerly awaits each local festival. His world unravels when the family's well dries up. Soon after, his father and then the rest of the family emigrate to the United States. While the story offers little more than anecdotal evidence of the connection between biophysical change and migration, the logic of this connection is supported by numerous sources showing water table drawdown beyond recharge, and the perceptions of local residents regarding environmental change.

\section{Current Land-Tenure Arrangements}

Sharecropping is a historic institution in this community, mentioned as early as 1935 in archival records and dating to the Spanish colonial period (Registro Agrario 
Nacional 2012; Taylor 1972). Current sharecropping arrangements appear to reflect the changes migration has brought to the supply and demand of land and labor in Santiago, as well as the increased scarcity of irrigated land that has resulted from aquifer drawdown. Thus, we see different outcomes in sharecropping arrangements on rainfed versus irrigated lands, and new opportunities for sharecroppers oriented towards rainfed maize production.

In Santiago, sharecropping contracts fall into two general categories, a medias and por partidas. The first kind of contract, a medias, refers to an arrangement whereby the landowner and sharecropper split the harvest equally, 50-50. The second kind of contract, por partidas, indicates that the landowner keeps less of the harvest and the sharecropper more, generally $2 / 3$ or $3 / 4$ of the harvest. The arrangement is similar to a traditional a medias contract, except that more of the risks, costs and potential benefits are borne by the sharecropper. However, results of the sharecropping survey I conducted reveal differences in sharecropping arrangements on rainfed land, on which traditional maize is grown, and on irrigated land that can support cash crops (Appendix C, Tables C.1 and C.2).

\section{Sharing on Rainfed Land}

In half of the sharecropping arrangements described to me for non-irrigated land suitable for maize $(\mathrm{N}=14)$, the agreement was for sharing a medias (Appendix $\mathrm{C}$, Table C.1). In the a medias arrangements on rainfed land, the landowner provides the land, frequently provides seed, and shares the cost of hiring a tractor to plough the land with the sharecropper. If the land requires ploughing and harrowing, the landowner commonly 
pays only the ploughing and the sharecropper pays the harrowing. Following this preparation by tractor plough, the sharecropper pays the cost of the furrowing process. This is performed by hired oxen team, horse or tractor. The sharecropper also bears the cost of any additional labor hired to accomplish the planting, weeding, and harvest, including the expense of fertilizer. He or she is responsible for depositing the landowner's half of the harvested maize at his or her doorstep. The sharecropper is then entitled to all of the zacate following harvest.

In just three of the 14 contracts found on rainfed land (21\%), the arrangement was described as por partidas (Appendix C, Table C.1). Under these por partidas arrangements, the landowner generally takes one-quarter to one-third of the harvest, and the sharecropper keeps two-thirds to three-quarters. However, the sharecropper bears the full burden of costs and risks associated with maize farming. One sharecropper who farmed por partidas explained the evolution of the arrangement: The sharecropper, seeking to improve the conditions of the a medias contract, began demanding more of the final share of the harvest. However, this provoked the landowner to invest less in the success of the harvest (in the form of paying for ploughings, providing seed, and assisting with fertilizer costs). The sharecropper who worked land por partidas was thus entitled to more of the harvest, but now bore the full costs of seed, tractor ploughings and fertilizer.

The a medias contract with rainfed lands may endure in Santiago because of the cost- and risk-sharing it provides to the sharecropper. Rather than assuming the full monetary costs of production, the sharecropper can generally count on the landowner to contribute seed and pay for at least one tractor pass. Likewise, the landowner stands to 
benefit from assisting the sharecropper (up to a point) because his or her share in the harvest is more substantial. By contrast, the por partidas contracts found in the community may be fewer because they lack any element of cost- and risk-sharing. Farming rainfed maize involves a great deal of risk, as the harvest is lost when planting is not timed appropriately to the rains.

Por partidas contracts may also be fewer because of the emergence of a similar nameless arrangement which favors the independent-minded sharecropper. This new arrangement appears to have developed with long term migrations, and characterized the remaining contracts discovered on rainfed land. In 10 of the 14 arrangements discovered for rainfed land (71\%), the landowner was either an absentee migrant or an absentee migrant's wife (Appendix C, Table C.1). In four of these 14 arrangements (29\%), the migrant landowner no longer asked for any share of the harvest - all was kept by the sharecropper.

Absentee landowners may lose the desire to sharecrop land out for any share of the harvest because they have no way to collect their shares from afar, because maize sold as grain is not particularly lucrative, and/or because they seek to limit investment in the farming process. However, landowners may wish to maintain the value of their land by keeping it under cultivation. If the land is not worked, it quickly becomes monte, overgrown with brush, scrub trees, and grasses that are arduous to remove. Moreover, letting arable land go to waste offends the local farming community's social commitment to cultivation. As one young man who rents his horse-plough services for hire explained to me, "God intends for the campesino to put the monte under maize cultivation." 
Another informant explained to me that property in the agricultural zone devalues substantially if left to grow grasses and brambles. The new land-sharing arrangement, which accounted for $29 \%$ of the arrangements discovered on rainfed land, may thus reflect the transformative influence of semi-permanent emigration. As of yet, there is no codified term to describe this arrangement whereby the sharecropper no longer farms on shares but rather provides a service to the land by cultivating it in the owner's absence.

The significance of this new arrangement may relate to the ultimate goals of migrants as well as the opportunities for farming rainfed maize it presents to local cultivators. There would be no reason for the landowner to maintain the land under cultivation by some other individual unless he or she intended to return to Santiago following a period of residence away, or at least leave open the possibility of returning. The arrangement of lending land out so that its value (market or cultural) is maintained suggests a continued investment in the sending community of Santiago. It also appears to generate a form of temporary land redistribution that is both theoretically and practically favorable for the sharecropper, and which supports the viability of continuing maize farming practices among those who remain in (or have returned to) the community.

In theory, contracting land out to sharecroppers offers an attractive option for labor-constrained households to keep their lands active. I had assumed that the femaleheaded households with a migrant husband abroad would be more likely to enter into sharecropping arrangements, as female-headed households have been shown to do in other parts of the world (Jarosz 1991). However, the results of this study did not support my assumption. The three female heads of household whose partners were in the United 
States during the fieldwork all pursued cultivation through hiring day laborers or leaving land in the care of trusted family members, rather than sharecroppers. I asked each of the female heads of household why they did not sharecrop their lands for maize, and all expressed that the sharecroppers demanded too much of the harvest or they demanded that the owners pay for "everything." One said that sharecroppers don't want to farm $a$ medias anymore, suggesting how absentee landowners may have skewed contracts to increasingly favor sharecroppers at the expense of capital- or labor-constrained landowners.

The shifting of sharecropping institutions on rainfed lands may reflect two potential pathways by which migration has impacted agricultural institutions. In the first instance, younger return migrants may show a reduced interest in laboring on others' land, while the older men in the community willing to sharecrop under traditional terms may have become scarcer with the passage of time. In the second instance, the availability of lands for contract without strings attached—with landowners who have migrated and want merely a caretaker but nothing of the harvest - may reduce interest in traditional sharecropping arrangements by their comparative advantages.

\section{Sharing on Irrigated Land}

While sharecropping arrangements on rainfed land appear to have evolved to favor land-constrained cultivators who have benefitted from landowner emigration, sharecropping arrangements on irrigated land appear to rarely involve absentee landowners (Appendix C, Table C.2). In the sample of contract arrangements on irrigated lands $(\mathrm{N}=9)$, only one involved an absentee landowner, and the arrangements appeared to 
either balance owner and sharecropper interests evenly or lean in the landowner's favor. This may be due to the increased constraints on farming cash crops presented by a diminished water table. For many capital- and land-constrained farmers, sharecropping is the only way to access groundwater for irrigated crops.

Sharing the harvest a medias characterized six of the nine sharecropping contracts I surveyed on irrigated lands (Appendix C, Table C.2). In these cases, the owner provided land and seed, as well as water and payment for electricity on the pump and half the ploughing costs. The sharecropper provided labor, and generally transported and marketed the harvest. The sharecropper then provided the owner with half of the cash income earned from sales.

Two of the arrangements on irrigated lands were por partidas contracts, and one was effectively equivalent to por partidas although the name used for the contract was $a$ medias (Appendix C, Table C.2). Where cash crops were sharecropped on irrigated land por partidas, the sharecropper bore the full costs of cultivation and kept three quarters of the harvest, or even more ( $4 / 5$ in one case), if responsible for harvesting the landowner's portion of the product. In this arrangement it was common for landowner and sharecropper to each harvest and sell his or her own share of the crop.

In general, irrigated lands appear to generate a more diverse distribution of workand investment- sharing arrangements than rainfed lands (Appendix C, Table C.2). This may reflect the diversity of contracts that can come about when both landowner and sharecropper are present in the community and can choose from a large array of potential 
cash crops to plant. Irrigated lands in Santiago can support a wide variety of flowers and vegetables, both criollo and improved varieties.

Landowners and sharecroppers generally agreed that the arrangements involving cash crops favored the landowners' interests rather than the sharecroppers' interests (Appendix C, Table C.2). The riskier, capital- and labor-intensive nature of cash crops may impact how the sharecropper views the arrangement with the landowner if the venture is unsuccessful even when the landowner is placed under similar quantity (but different quality) of risk. In the case of a crop failure or a drop in market price at harvest time, the landowner is unable to recuperate his capital investment while the sharecropper loses in-kind remuneration for his labor. In one case, I spoke with a sharecropper and a landowner (in separate interviews) who had formerly contracted together for an onion harvest. At harvest time, they had nice onions but the market price had dropped so low that it was not worth the labor of harvesting and sale. In disgust, the sharecropper described the earth turning white with onion flesh as it was ploughed through. The landowner explained that after this failure the sharecropper ceased contracting with him.

It is thus possible that migration and groundwater scarcity have enabled sharecropping arrangements on rainfed land to generally move in the sharecropper's favor, while arrangements on irrigated land remain favorable to the landowner. The contrast between arrangements available on rainfed and irrigated land suggests that both migration and groundwater scarcity may be forces contributing to the persistence of rainfed maize in the agricultural landscape. 


\begin{abstract}
$* * * * *$
From consideration of the survey results, archival data, and other observations presented and analyzed in this chapter, it appears possible that traditional agricultural practices centering on subsistence maize, observed in the migrant households surveyed in the previous chapter, may be influenced by migration and groundwater depletion. Taken together, the changes in land-labor relations that migration appears to engender, along with actual and perceived biophysical changes in the land (particularly groundwater scarcity), may suggest a new logic for agricultural strategies oriented towards rainfed maize cultivation, such as those observed among Santiago's migrant households. Both migration and groundwater scarcity appear to have limited the underlying landscape for irrigated agriculture and opened land constraints for non-migrant and return-migrant farmers willing to produce rainfed maize. Sharecropping arrangements may provide a cipher for some of the landscape-level changes in land-labor relations deriving from various effects of migration and environmental change. Current agricultural practices thus appear to reflect not a simple endurance of tradition, but rather adaptations to community-wide changes in the means of production that correspond to different agricultural orientations.
\end{abstract}




\section{Chapter Six: Discussion}

With respect to land that households allocate to the community's locallydeveloped varieties of rainfed maize, and household production of this staple crop, little has changed with international migration practices of the household head. Migration has not modified the community's longstanding household-level agricultural orientation towards "satisfaction in maize" (Kirkby 1973), characterized by production of approximately one ton of maize per family per year, nor has it modified the general percentage of land allocated to rainfed maize. While basic production practices discovered remain very similar to those documented 50 years ago, before migration was commonplace livelihood activity in Santiago Apóstol, the data from mixed methods employed in this study suggest that continuity in production and land use may be a product of change rather than stasis.

Community-wide changes in the means of production-land, labor, knowledge and capital — offer a useful conceptual framework for synthesizing the findings from mixed-methods analysis into a speculative discussion of the broader forces that may be driving continuities in migrant households' agricultural orientations observed. All production relies upon three primary factors: land, labor and capital, plus an additional measure of essential knowledge and/or skill. Considering changes in the factors of production essential to all agriculture enables a comprehensive discussion of the results found in migrant households' farming decisions as well as community-level processes of change. 
In Santiago, factors of production appear to have undergone fundamental shifts. In particular, access to irrigated land has become more dependent upon capital resources. Both migration and new efforts by the Mexican government to educate and urbanize the rural sector appear to have generated labor constraints. These changes may have also shifted the knowledge basis for traditional agricultural livelihoods. Labor scarcity may have driven up the capital costs of farming maize, which is still a labor-intensive process. The high capital costs of farming today may make market sale of homemade tortillas and household animals, among other livelihood diversifications (including migrations), essential for reproducing the basic subsistence cycle.

\section{Changes in Agricultural Land}

Key changes in the underlying biophysical qualities of agricultural land may help to explain the continuity in household agricultural practices dedicated to maize. First, regional overdraw of the water table, linked to urbanization and possibly other factors which remain to be explored in future research, has modified agricultural lands in Santiago. A drop of several meters in the water table appears to have made irrigation infrastructure much more costly, a fact that may be influencing the land area dedicated to rainfed maize.

Climatic shifts that would dramatically impact agriculture appear in data from the capital city approximately 30 kilometers away, yet are not reflected in the local climate data, probably due to a combination of topographic variation between these locations and the urbanization that has occurred in the capital city in the past 50 years. Local perceptions of a long-term climatic shift in Santiago appear to reflect select drought and 
flood events, as well as changes in the built environment and material culture that may be decreasing soil moisture and contributing to a lowered water table. Groundwater pumping for urban growth in the capital, and regional commercial agricultural projects dating to the 1970s likely form relatively larger forces driving aquifer drawdown.

Rainfed land appears to become available for contract farming due to absentee landowners who wish to maintain their land under cultivation. The terms of sharecropping arrangements on rainfed lands appear to have shifted to favor the sharecroppers, several of whom grow maize on absentee migrants' land, bearing the full costs of production, but who no longer have to give the landowner any shares, nor pay rent. Analysis of sharecropping contracts affirms the continued risk-averse nature of maize in comparison to irrigated cash crops, especially improved varieties of flowers and vegetables that only grow under prescribed climactic conditions and require a host of costly inputs. The constraints of local climate and the uncertainties of market production may combine to make engagement in capitalist agriculture both difficult and risky, and to reinforce the logic of investment in maize agriculture.

\section{Changes in Labor and Knowledge}

As a result of integration with the broader capitalist economy through increases in formal education, and faster means of transportation and communication that bring the city to the country and vice versa, subsistence agriculture in Santiago has become increasingly monetized, and technological shifts have occurred. Scarcity of labor associated with migration appears to have contributed to these processes. 
Households today use tractors, horse-ploughs and new harvesting methods, which all reflect time- or labor-saving innovations. Maize agriculture remains labor intensive, although it appears to be less labor-intensive that cash crop agriculture. The labor input required for cash crops may thus form an additional check on increased cash-crop agriculture. Beyond technological modifications in agricultural practice, changes in technology encompass the motor taxi services that have emerged in Santiago to serve a broader economic interface with the city. (Ownership of a vehicle is uncommon in Santiago, even among migrant families.) Neighboring Ocotlán and the capital city 30 kilometers north, both with expanding urban populations, offer the consumer markets for Santiago's prepared foods and produce. The taxis' customer base consists of producers riding to the city to sell vegetables, flowers, and prepared foods.

In observing technological change, the pressures of time-space compression and labor scarcity in transforming maize cultivation practices are evident. However, the reasons for growing maize may remain strong in comparison with either leaving agriculture altogether or switching entirely to cash crops, as maize enables selective market integration and maintenance of the subsistence cycle that secures household reproduction.

\section{Changes in the Role of Capital}

The role of capital and its movement in defining the importance of maize for the migrant households surveyed speaks to a broader process of integration into the broader capitalist economy. National and state government policies have actively induced this integration at multiple scales, with efforts to modernize unprofitable elements of Mexican 
agriculture, including its small-scale, subsistence-oriented producers. Economic liberalization policies have placed Oaxaca's producers in a position of substantial inequality on a poorly regulated international market. According to the farmers, they are also poorly positioned to compete with growers from Puebla and other Mexican states, perceptions supported by recent research on the evolution of Mexico's agricultural policies (Appendini 2013).

Consequently, integration with the national and global capitalist economies does not appear to have produced economic conditions in which Santiago's families can safely throw their bets in with a liberal market society. Unfavorable market conditions for those who depend on a small-scale farming livelihood in Santiago and likely in many areas of rural Mexico may combine with the demand for wage labor in the United States to spur migration North, mostly by men, and local strategies of selective, flexible market integration, mostly on the part of women, in order to maintain households' subsistence reproductive cycles.

While new technologies and shifts in cultivation techniques have cut down on both the labor and capital costs of farming maize, these remain formidable. Labor scarcity and the attendant monetization of labor are significant factors in the costs associated with maize farming. In addition, sharecroppers of rainfed lands often bear the full burden of capital investment formerly shared by the landowner (including ploughing and fertilizer costs) now that a tenant may retain the full harvest. Nevertheless, the capital costs of cultivation remain higher for cash crops than for subsistence maize, especially with respect to development of irrigation infrastructure. Moreover, the risks involved in 
dedicating all resources to cash crops, whose price is never assured and whose use-value is limited in the context of a buyer's market (recall the situation of onions described in the preceding chapter), make abandonment of rainfed maize agriculture impractical for Santiago's resource-constrained and risk-averse farmers. Ever-scarcer water resources only reinforce this logic.

It is worth illustrating the challenges that Santiagueños face in the contemporary economic integration process known as globalization, in which communication and transportation modes have brought the global to the local and vice versa. As a result of instituted processes wherein the price of goods traded is regulated by the international market, the price of food and clothing available for purchase is extremely high for Santiago's capital-constrained farmers. At the local market a slaughtered chicken costs \$70 MXN, approximately \$6 USD, which is similar to the cost of a chicken at a grocery store in the United States. The difference is that in rural Mexico, the price of a chicken is half of the going daily wage, whereas it constitutes one-tenth of a day's income from a minimum wage salary in Oregon. The cost of shoes, clothes and other expenses are similarly high in Santiago relative to the wages available.

How do rural residents get the capital increasingly required for everyday life, as well as for subsistence farming? Migration for wage labor in the United States is often chosen as a form of capital accumulation under conditions of rising costs of living and the lack of capital profits to be had in traditional agriculture. Theoretically, savings from wage labor abroad can be augmented by the exchange rate between the two countries if the laboring family member is able to keep his costs down while away. 
However, international migration does not always result in capital accumulation, even if the migrant's commitment to save and remit is sincere. Informal conversations revealed that there is a wide range of behavior with respect to remittances and that remitting depends upon success abroad and the personal characteristics and choices of the migrant. Various attitudes and situations suggest the cultural expectation that migrant husbands send money to their wives in Santiago. However, remitting regularly is not a guaranteed outcome of the husband's period abroad. Migrants are even less likely to remit earnings to their parents, especially when they have already begun their own households, a pattern observed in other migrant communities in Oaxaca (Gabbarot and Clarke 2010). In sum, migrant remittances do not offer a reliable social safety net for those who remain in Santiago.

Accordingly, food costs remain high, and migrant households' capital constraints remain significant. The costs of purchasing maize for household consumption, feed for household animals (which are also consumed) and/or meat, and fuel for the cookfire would depend on having a secure, regular and adequately high income. This type of employment is uncommon. As a result, migrant households may seek to maintain a subsistence cycle of food dependent on maize agriculture despite its increased monetary costs, while simultaneously engaging in risk-averse market-based activities. Maize farming appears rationalized by the use value of maize in household reproduction and its flexible exchange value when transformed by women's labor into prepared foods that generate cash income but also serve to secure the household food supply. 


\begin{abstract}
$* * * * *$
Considering these changes in the means of production — in land, labor, knowledge and capital — it becomes evident that maize agriculture may remain important to migrant households for several reasons. Water table drawdown may have made use of Green Revolution crops possible on a minority of Santiago's lands given most landowners' capital resource constraints. Institutional shifts in land and labor relations may have made land for maize cultivation more available for those willing to work than it was before migration activity. An increase in urbanized populations may have increased the demand for tortillas and prepared foods as commercial extensions of subsistence-oriented agricultural livelihoods. Far from being measured by its market value as grain, the value of maize appears to be reflected in women's commercially-oriented, yet subsistencesecure, home manufacturing activities, the most prevalent of which is preparing tortillas for sale. With dimensions that make rainfed maize a source of resilience beyond subsistence, the persistence of maize in Santiago may thus reflect household adaptation to broader changes in nature-society relations that have taken place in Oaxaca's Central Valley over the past half-century.
\end{abstract}




\section{$\underline{\text { Conclusion }}$}

This thesis used a baseline study from 1973 and an ethnographic survey among migrant households to address whether, at a household-level, migration has modified longstanding subsistence agricultural practices centered on local varieties of rainfed maize. Upon finding that household-level agricultural practices in migrant households were oriented to rainfed maize at levels comparable to those previously documented (Kirkby 1973), I used triangulated, mixed-methods methodologies to explore two landscape-level drivers of change - migration and biophysical change — as potential explanatory variables for the continuity observed in migrant households' agricultural practices.

Survey results showed that agricultural families of migrants abroad and returned to the community dedicate an average of $74 \%$ of the agricultural land they own or contract to traditional, rainfed varieties of maize. Eighty-two percent use maize for household subsistence. More than a quarter use maize in value-added prepared foods destined for market. Migrant households appear to be using maize as the basis of a variety of risk-averse, subsistence-secure livelihoods. These include direct household provisioning, sale of animals, and sale of maize-based foods prepared by the households' women.

Results of triangulated, mixed-methods analyses exploring the potential drivers for continuities in subsistence agricultural practices in migrant households revealed several avenues for future research. Water table depletion appears to be a strong potential 
factor of landscape-level change reducing the practicability of Green Revolution agriculture. Limits to irrigation may constrain expansion of commercial agricultural endeavors by households that would otherwise happily transition to higher-yield, irrigation-dependent crops and technology packages. Migration also appears to influence agriculture in the landscape, through several pathways. Labor scarcity resulting from migration may have increased the capital costs associated with farming, making reliance on labor-sharing arrangements and use of mechanization and non-mechanized technological changes to reduce labor time widespread. Absentee migrants with an eye towards ensuring future cultivation options may have temporarily loosened land constraints and made conditions for farming maize among land-constrained households more favorable to sharecroppers. Finally, practices documented among agricultural, migrant households reveal that traditional maize production is often destined for commercial sale as tortillas or other maize-based foods as well as for household consumption, suggesting a more nuanced meaning of "subsistence" agriculture in modern, rural Mexico than was formerly understood (Kirkby 1973).

The findings herein are useful for offering a revision of earlier predictions for the Central Valley on the whole that irrigated cash crops would become more dominant, or that agriculture would be abandoned altogether with migration. Dilley (1993) imagined capitalist rationales engulfing Oaxaca's traditional agricultural sector in the event of increased moisture from global climate change, or in an alternative climate change scenario, more frequent droughts leading to permanent emigration out of the agricultual sector. Kirkby (1973) noted that an orientation towards satisfaction rather than profit 
characterized most peasant producers, and that the increasing commercialism of some Central Valley producers would find biophysical limits on aquifer pumping. While the incomplete climate record analyzed herein does not point to a clear outcome from global climate change, a well-documented drop in the water table has most certainly placed constraints on irrigated agriculture, and perhaps also led to migrations from Santiago, a worthwhile avenue for future research. Moreover, return migration appears to form an important new element in these human-environment dynamics, as some migrants invest in digging deeper wells upon returning to the community. These dynamics merit further research.

In the context of a water table drop and engagement in the international economy through migration, use of rainfed maize appears to have formed an important livelihood orientation for Santiago's women. Considering the apparently insecure nature of labor migrations suggested by high rates of return migration to Mexico and Santiago in the wake of the Great Recession (see Chapter 3 and Passel, et al. 2012), and the impracticability of modernized agriculture in the absence of irrigation, many migrant families may invest their time and energy in traditional, rainfed maize as a risk-averse orientation. Current agricultural orientations appear to reflect the community's women using maize to generate the capital income necessary to feed and clothe their families, possibly because investments in migration have been insecure. In the face of economic and environmental vulnerability, primary production that doubles as subsistence and as the basis for profit-oriented activity by the community's women may form an important survival strategy for the entire household. 
The findings of this research have important implications for the role of gender in the political economy of U.S.-Mexican migration. Current orientations with maize are strongly dependent on the labor of Santiago's women, who have until very recently had almost no access to formal education. The value they add to maize in the form of tortillas and other foods for urban markets generates the capital income increasingly necessary for household reproduction in the context of economic globalization (including labor migration from Mexico to the United States) and increased resource scarcity. Santiago's migrants' low-wage, temporary contributions to the economy of the United States appear to have disproportionately depended upon the reproductive labor of their mothers, wives and sisters back home, reflecting unequal relationships at various scales and offering empirical support to the ideas of previous labor-migration researchers (Wilson 2000). In contrast with their male counterparts, the relatively fewer young women who have migrated from Santiago to the United States appear to have migrated permanently, perhaps for this reason.

Yet this burden on women, and the access to fresh and homemade foods it guarantees to their households and the increasingly urbanized populations of Oaxaca, may one day shift. Cultivation of subsistence maize and local sale of homemade tortillas appear to be livelihood strategies borne of necessity rather than preference. Changes in education in Santiago and throughout rural Mexico that increasingly prepare women as well as men for professions outside of the home in the secondary and tertiary economic sectors may be an ultimate factor of change in both agricultural orientations and migration dynamics in this community. A shift in both the knowledge base and the labor 
market desires of Santiago's youngest generation appears underway. If current government policies oriented towards urbanizing and integrating rural Oaxaca's new generations into the state and national economies are successful, Santiago's agricultural landscape is apt to change dramatically.

As Santiago's youngest generation grows up, some will undoubtedly continue farming maize. Yet if education policies and efforts to offer broader access to financial services in rural Mexico succeed, many residents holding just a few small farm parcels may ultimately sell or abandon them. Meanwhile, new paved roads will likely be built with government subsidies, which will increasingly facilitate Santiago's connections with surrounding markets. New roads will increase the value of Santiago's agricultural and urban lands to individuals outside of the community. At just 30 kilometers from the capital city, Santiago could one day become desirable peri-urban real estate. If enough residents choose to sell their agricultural land, this may ultimately cease to be controlled by the traditional laws and mores of the community.

Likewise, comprehensive reform in the United States immigration system may influence the future of agricultural traditions in Santiago. A new pathway to legal status for those who wish to remain abroad long-term could result in a lessening of the capital constraints that tend to reinforce risk-averse farming traditions. Future legalization policy may also enable family-based petitions for the relatives of migrants residing in Santiago. However, all derivative legalization processes will be slow, and the border securitization measures and employment-verification programs embedded in future legalization policies thus far considered by Congress may result in a great deal of return migration to Mexico, 
depending on implementation and enforcement. Ultimately, regardless of immigration policies and enforcement measures, future migration will likely continue to follow the broader political-economic cycles governing supply and demand for low-wage labor that have spurred and slowed migration in the past. If labor security for migrants and wouldbe migrants from Mexico’s “modern peasantry” does not improve, one might reasonably expect to find this sector of the population defending their landholdings and risk-averse agricultural traditions for a long time yet (Barkin 2002).

This investigation into household level farming practices among migrant-headed households in a rural Mexican community has revealed some of the economic and environmental complexities inherent in U.S.-Mexico migration. This complexity is often left out of analyses that focus on the migrant's journey, the lives of migrants in the United States, or the effect of migrant remittances back home. It is certainly left out of popular discourse on immigration in the United States media, which encourages the false perception that all immigrants move to the United States with intentions of remaining permanently. The agricultural landscape and farming practices of migrant-headed households in Santiago Apóstol today reveal that the United States is, for many migrants, a means to an end in Mexico, rather than a new beginning abroad. Local, rainfed maize appears to form an important social safety net for migrant-headed households confronting the challenges of late- $20^{\text {th }}$ century economic restructuring, the vagaries of international labor migration, and the changing environmental resources in their sending-community landscape. 


\section{Bibliography}

Alba, F. and Potter, J.E. 1986. Population and Development in Mexico since 1940: An Interpretation. Population and Development Review 12(1): 47-75.

Appendini, K. 2013. Restructuring the maize Market in Rural Mexico. Journal of Agrarian Change (in press).

Banco de Mexico, 2012. Ingresos por remesas Familiares: Distribucion por Entidad Federativa. URL: http://www.banxico.org.mx/SieInternet/consultar DirectorioInternetAction.do? accion $=$ consultarCuadroAnalitico\&idCuadro $=$ CA79 \&sector $=1 \&$ locale $=$ es $($ Last accessed 6/13/2013)

Barkin, D. 2002. The reconstruction of a modern American peasantry. Journal of Peasant Studies 30(1): 73-90.

Campos Cornelio, M. L. 2012a. Desarollo Sustentable de los Municipios de Ocotlán de Morelos, San Antonino Castillo Velasco y Santiago Apóstol. Unpublished Master's Thesis. Oaxaca de Juárez, Mexico: Instituto Tecnológico de Oaxaca. 2012b. Personal Communication.

Chambers, K. and Momsen, J. 2007. From the kitchen and the field: Gender and maize diversity in the Bajío region of Mexico. Singapore Journal of Tropical Geography 28:39-56.

Cohen, J.H. and Rodriguez, L. 2005. Remittance Outcomes in Rural Oaxaca, Mexico: Challenges, Options and Opportunities for Migrant Households. Population, Space and Place 11: 49-63.

Cohen, J. 2004. The Culture of Migration in Southern Mexico. Austin: University of Texas Press.

Colin, J. 1997. Sharecropping and Peasant Rationality in a Zapotec Village (Oaxaca, Mexico) Preliminary Paper prepared for the meeting of the Latin American Studies Association in Guadalajara, Mexico, April 17-19, 1997.

------ 2005. Some Rationales for Sharecropping: Empirical Evidence from Mexico. Human Organization 64(1): 28-39.

CONAGUA. 2001. (Comision Nacional del Agua, Gerencia Regional Pacifico Sur, Subgerencia Tecnica). Estudio de Actualización Geohidrológica del Acuífero de Valles Centrales, Estado de Oaxaca. Oaxaca: Copei Ingenieria, S.A. de C.V. 
2012. Spreadsheet of Water Table Measurements. Obtained directly from engineers at CONAGUA headquarters in Oaxaca City on July 19, 2012.

------ 2013. Spreadsheet with Data on Temperature, Evapotranspiration, and Precipitation. Obtained directly from engineers at CONAGUA headquarters in Oaxaca City via e-mail correspondence in July and August 2013.

Creswell, J.W. 2003. Research Design: Qualitative, Quantitative, and Mixed Methods Approaches. Thousand Oaks: Sage Publications.

DeJanvry, A. and Sadoulet, E. 2001. Income Strategies Among Rural Households in Mexico: The Role of Off-Farm Activities. World Development 29(3): 467-480.

Dilley, F. B. 1993. Climate Change and Agricultural Transformation in the Oaxaca Valley, Mexico. Penn State University doctoral dissertation. Ann Arbor: UMI.

Eakin, H. 2000. Smallholder Maize Production and Climactic Risk: A Case Study from Mexico. Climactic Change 45: 19-36.

2005. Institutional change, climate risk, and rural vulnerability: Cases from central Mexico. World Development 33(11): 1923-1938.

2006. Weathering Risk in Rural Mexico: Climactic, Institutional, and Economic Change. Tucson: University of Arizona Press.

Eakin, H., A. M. Lerner, and F. Murtinho. 2010. Adaptive capacity in evolving periurban spaces: Responses to flood risk in the Upper Lerma River Valley, Mexico. Global Environmental Change 20: 14-22.

Esparza, M. 1988. Los proyectos de los liberales en Oaxaca (1856-1910). In Reina, L., ed., Historia de la Cuestión Agraria Mexicana. Estado de Oaxaca. Prehispánico - 1924. Volumen 1. Mexico City: Juan Pablos Editor, S.A.

Fitting, E. 2006. Importing corn, exporting labor: The neoliberal corn regime, GMOs, and the erosion of Mexican biodiversity. Agriculture and Human Values 23: 15-26. 2011. The Struggle For Maize. Campesinos, Workers and Transgenic Maize in the Mexican Countryside. Durham: Duke University Press.

Fletcher, P. L. 1999. La casa de mis sueños: Dreams of home in a transnational Mexican community. Westview Press: Boulder, CO. 
Gabbarot, M. and Clarke, C. 2010. Social Capital, Migration and Development in the Valles Centrales of Oaxaca, Mexico : Non-Migrants and Communities of Origin Matter." Bulletin of Latin American Research 29 (2): 187-207.

Goodman, G.L. and J.T. Hiskey. 2012. Exit Without Leaving: Political Disengagement in High Migration Municipalities in Mexico. Comparative Politics 40 (2): 169-188.

Gray, C. 2009. Rural out-migration and smallholder agriculture in the southern Ecuadorian Andes. Population and Environment 30: 193-217.

Hewitt de Alcántara, C. 1976. Modernizing Mexican Agriculture: Socioeconomic Implications of Technological Change. Geneva: United Nations Research Institute for Social Development.

Hunter, L.M., Murray, S. and Riosmena, F. 2011. Climatic Variability and U.S. Migration from Mexico. Working paper for the Institute of Behavioral Science. Boulder: University of Colorado. URL: http://www.colorado.edu/ibs/pubs/pop/pop2011-0003.pdf (Last accessed 10/1/2013).

INEGI 2010. Principales Resultados del Censo de Poblacion y Vivienda. Available at http://www.inegi.org.mx/prod_serv/contenidos/espanol/bvinegi/productos/censos/ poblacion/2010/princi_result/cpv2010_principales_resultadosiv.pdf (Last Accessed 3/19/13)

2012a. Web page showing municipality-level detail on population characteristics. URL: http://www.inegi.org.mx/sistemas/mexicocifras/default.aspx (Last accessed 5/17/2012).

2012b. Web page showing percentage of population of each Mexican state that has migrated to establish residence internationally between 2005 and 2010. URL: http://www.inegi.org.mx/sistemas/sisept/Default.aspx?t=mdemo $142 \& \mathrm{~s}=\mathrm{est} \& \mathrm{c}=27507$ (Last accessed 3/17/2012)

2012c. Web page showing distribution of Oaxaca's population by size of population center/locality. URL: http://www.inegi.org.mx/sistemas/sisept/ Default.aspx? $\mathrm{t}=$ mdemo13 \&s=est\&c=17503 (Last accessed 5/13/12)

2013. Censos y Conteos de Poblacion y Vivienda para 1970, 1980, 1990, 1995, 2000, 2005 y 2010. URL: http://www.inegi.org.mx/est/contenidos Proyectos/ccpv/default.aspx (Last accessed 10/07/2013)

Jarosz, L. 1991. Women as rice sharecroppers in Madagascar. Society and Natural Resources: An International Journal 4(1): 53-63. 
Jokisch, B. 2002. Migration and Agricultural Change : The Case of Smallholder Agriculture in Highland Ecuador. Human Ecology 30(4): 523-550.

Kirkby, A. 1973. The Use of Land and Water Resources in the Past and Present Valley of Oaxaca, Mexico. Ann Arbor: University of Michigan Press.

Marcelli, E.A. and Cornelius, W.A. 2001. The Changing Profile of Mexican Migrants to the United States: New Evidence from California and Mexico. Latin American Research Review 36(3): 105-

Mason, D. R., and V. A. Beard. 2008. Community-based Planning and Poverty Alleviation in Oaxaca, Mexico." Journal of Planning Education and Research 27 (3) (March 1): 245-260.

Maya Padilla, A. and Cortes Cortes, M. 2011. "Santiago Apóstol, Ocotlán, Oaxaca. Plan de Desarrollo Municipal. Periodo 2011-2013." Santiago Apóstol: H. Ayuntamiento Constitucional de Santiago Apóstol, Ocotlán, Oaxaca. URL: http://www.finanzasoaxaca.gob.mx/pdf/inversion_publica/pmds/11_13/452.pdf (last accessed 3/5/2013)

Momsen, J. 2004. Gender and Development. London: Routledge.

Nagengast, C. and Kearney, M. 1990. Mixtec Ethnicity: Social Identity, Political Consciousness, and Political Activism. Latin American Research Review 25(2): 61-91.

Nelson, L. 2008. Farmworker Housing and Spaces of Belonging in Woodburn, Oregon. The Geographical Review 97(4): 520-541.

Nolasco, M. 1992. Migración Indígena y Etnicidad. In Migración y Etnicidad, Eds. J. Corbett, M.A. Musalem Merhy, O. Rios Vasquez, and HA Vasquez Hernandez. Vanderbilt University Publications in Anthropology No. 43.Nashville: Vanderbilt University Press.

O'Brien, K. L. and R. M. Leichenko. 2000. Double exposure: assessing the impacts of climate change within the context of economic globalization. Global Environmental Change 10: 221-232.

Otero, Gerardo. 2011. "Neoliberal Globalization, NAFTA, and Migration: Mexico's Loss of Food and Labor Sovereignty." Journal of Poverty 15 (4) (October): 384-402. 
Passel, J., Cohn, D. and Gonzalez-Barrera, A. 2012. Net Migration From Mexico Falls to Zero-And Perhaps Less. PEW Hispanic Center Report. Washington D.C.: PEW Research Center.

Pita-Duque, A. 2000. Impact on Maize Diversity of Mexican Farmers' Participation in Off-Farm Labor Markets. University of California, Davis doctoral dissertation. Ann Arbor: UMI.

Preibisch, K. L, G. Rivera Herrejon, and S. L. Wiggins. 2002. Defending Food Security in a Free-market Economy: The Gendered Dimensions of Restructuring in Rural Mexico. Human Organization 61 (1): 68-76.

Preston, D. and Taveras, G. 1980. Changes in land tenure and land distribution as a result of rural emigration in Highland Ecuador. Tijdschrift voor Economische en Sociale Geografie 71: 98-107.

Rees, M. 2006. Migration in Times of Globalization: The Central Valleys of Oaxaca, Mexico. Research in Economic Anthropology 25: 27-50.

Registro Agrario Nacional. 2012. Santiago Apostol Archive. Consulted in person at the Oaxaca City offices of the Registro Agrario Nacional on July 19 and 20, 2012.

Reina, L. 1988. De las Reformas Borbonicas a las Leyes de Reforma. In Reina, L., ed., Historia de la Cuestión Agraria Mexicana. Estado de Oaxaca. Prehispánico - 1924. Volumen 1. Mexico City: Juan Pablos Editor, S.A.

Riosmena, F. and Massey, D. 2012. Pathways to El Norte : Origins, Destinations, and Characteristics of Mexican Migrants to the United States. International Migration Review 46 (1): 3-36.

Rose, G. 1997. Situating knowledges: positionality, reflexivities and other tactics. Progress in Human Geography 21(3): 305-320.

Santibañez, L., G. Vernez and P. Razquin. 2005. Education in Mexico: Challenges and Opportunities. Santa Monica: RAND Corporation. Available at: http://www.worldfund.org/assets/files/RAND_Education\%20in\%20Mexico.pdf (Last accessed 3/21/13)

Saldaña-Zorilla, S. O. 2008. Stakeholders' views in reducing rural vulnerability to natural disasters in Southern Mexico: Hazard exposure and coping and adaptive capacity. Global Environmental Change 18: 5830597.

Schiller, N.G., Bash, L., and Szanton Blanc, C. 1995. From Immigrant to Transmigrant: Theorizing Transnational Migration. Anthropological Quarterly, 68(1): 48-63. 
Smith, H. and Furuseth, O. 2006. Latinos in the New South: Transformations of Place. Burlington: Ashgate.

Stephen, L. 2007. Transborder Lives: Indigenous Oaxacans in Mexico, California, and Oregon. Durham: Duke University Press.

Taylor, W. B. 1972. Landlord and Peasant in Colonial Oaxaca. Palo Alto: Stanford University Press.

U.S. Census Bureau. 2012. Statistical Abstract of the United States. Washington D.C.: U.S. Department of Commerce. URL: http://www.census.gov/compendia/statab/ (Last accessed 9/20/13)

Verduzco, G. and Unger, K. 1998. "Impacts of Migration in Mexico." Conference proceedings: Migration Between Mexico and the United States: Binational Study. URL: http//www.utexas.edu/lbj/uscir/ binpapers/v1-4b-verduzco.pdf (Last accessed 3/17/2012).

Wiest, R. 1978. Implications of international labor migration for Mexican rural development. University of Manitoba anthropology papers, no. 21. Winnipeg: Dept. of Anthropology, University of Manitoba.

Wilson, T. D. 2000. Anti-immigrant Sentiment and the Problem of Reproduction/ Maintenance in Mexican Immigration to the United States. Critique of Anthropology 20(2): 191-213.

Winter, M. 1988. Período Hispánico. In Reina, L., ed., Historia de la Cuestión Agraria Mexicana. Estado de Oaxaca. Prehispánico - 1924. Volumen 1. Mexico City: Juan Pablos Editor, S.A.

Wright, A. 1990. The Death of Ramon Gonzalez: The Modern Agricultural Dilemma. Austin: University of Texas Press.

Zimmerer, K. 1991. Labor Shortages and Crop Diversity in the Southern Peruvian Sierra. Geographical Review 81(4): 414-432. 
Appendix A: Human Subjects Approval Notice and Approval of Continuation 


\section{Portland State University HSRRC Memorandum}

To: Fiona Gladstone

From: Mary Oschwald, Chair, HSRRC 2012

Date: June 18, 2012

Re: Your HSRRC application titled, "Peasant Agricultural Traditions and International Outmigration in the Central Valley of Oaxaca" (HSRRC Proposal \#122160)

In accordance with your request, the Human Subjects Research Review Committee has reviewed your proposal referenced above for compliance with DHHS policies and regulations covering the protection of human subjects. The committee is satisfied that your provisions for protecting the rights and welfare of all subjects participating in the research are adequate, and your project is approved.

Please note the following requirements:

Changes to Protocol: Any changes in the proposed study, whether to procedures, survey instruments, consent forms or cover letters, must be outlined and submitted to the Chair of the HSRRC immediately. The proposed changes cannot be implemented before they have been reviewed and approved by the Committee.

Continuing Review: This approval will expire 06/18/2013, one year from the approval date. It is the investigator's responsibility to ensure that a Continuing Review Report (available in ORSP) of the status of the project is submitted to the HSRRC approximately two months before the expiration date, and that approval of the study is kept current.

Adverse Reactions: If any adverse reactions occur as a result of this study, you are required to notify the Chair of the HSRRC immediately. If the problem is serious, approval may be withdrawn pending an investigation by the Committee.

Completion of Study: Please notify the Chair of the Human Subjects Research Review Committee (campus mail code ORSP) as soon as your research has been completed. Study records, including protocols and signed consent forms for each participant, must be kept by the investigator in a secure location for three years following completion of the study.

If you have questions or concerns, please contact the HSRRC in the Office of Research and Strategic Partnerships, Market Center Building, Suite 620, 1600 SW Fourth Ave, Portland OR 97207 (503)725-2243.

cc: Andrea Haack 


\section{Portland State University HSRRC Memorandum}

Date: June 7, 2013

To: Fiona Gladstone

From: Melissa Thompson, Chair, HSRRC 2013

Re: HSRRC renewal of approval for your project entitled, "Peasant Agricultural Traditions and International Outmigration in the Central Valley of Oaxaca" (HSRRC Proposal \#122160)

As part of the Committee's continuing review, the Human Subjects Research Review Committee has reviewed your above referenced project for compliance with Department of Health and Human Services policies and regulations on the protection of human subjects.

The Committee is satisfied that your provisions for protecting the rights and welfare of all subjects participating in the research are adequate. Your project is renewed and this approval will expire on 6/18/2014. Please note the following policies:

1. If the project continues beyond the expiration date, the investigator needs to submit a Continuing Review Report form (available in the Office of Research \& Strategic Partnerships) two months before the expiration date.

2. To add this project's continuing review to the HSRRC/IRB meeting agenda, please refer to the HSRRC/IRB meeting schedule. Submit the report, and the required number of copies, by the submission deadline that is approximately two months before the project's expiration date. The HSRRC/IRB needs two months to do a continuing review of the project, so it is extremely important that you meet the committee's submission deadline.

3. If this project finishes before the expiration date, please contact the HSRRC administrator so that the file can be closed and records updated. It is the investigator's responsibility to keep the approval status current. If the project's approval expires while the project is active, the investigator must complete new application and submit it for a new HSRRC review. In addition, any data collected after the expiration date cannot be used in the research. Please don't let this happen!

If you have questions or concerns, please contact the HSRRC in Research and Strategic

Partnerships (RSP), hsrrc@pdx.edu, or at (503) 725-2227. 
Appendix B: Survey Instrument 
New Research Instrument HSRRC Proposal \#122160

\section{Questions for Household Production/Consumption Survey}

How many people live in this/your house?

¿Cuántas personas viven en esta/su casa?

How many of you eat together?

¿Cuántas comen juntos?

How old is each household member?

¿Cuantos años tienen cada uno?

Have you lived in the United States? (Which years? Where did you live?)

¿Viviste en los EEUU? (¿Cuáles años? ¿Dónde radicabas?)

Who else in the family lives/has lived in the United States? (Which years? Where did they live?)

¿Quién más de la familia vive o ha vivido en los EEUU? (¿Cuáles años? ¿Dónde radicaba?)

Do you grow corn?

¿Cultivas maiz?

Do you grow other crops?

¿Cultivas otros cultivos?

How do you sow your corn (yunta, horse, tractor?)

¿Cómo siembras, con yunta, caballo, o tractor?

Do you use fertilizer? Organic or chemical? How much?

¿Usas fertilizante? ¿Abono o químico? ¿Cuánto usas?

Do you use insecticide or herbicide?

¿Usas insecticidio o herbicidio?

Who helps you with the farming? (family members / hired labor /labor exchange with whom?)

¿Quién de la casa ayuda a cultivar? (familiares, mozos, guelagueza ¿con quiénes?)

How much land do you own? (Number of parcels and size of each parcel, list main crops) ¿Cuántos terrenos tiene usted? (Número y tamaño, ¿qué cultivan en cada uno?) 
Would you show me your parcels?

¿Me mostrarías tus parcelas?

This year, how much land are you cultivating?

¿Cuánta tierra tienes activo este año?

How much are you leaving fallow?

¿Cuánta tierra tienes en descanso?

Is someone else cultivating the land you own?

¿Es que otra persona cultiva terrenos tuyos?

Are you sharecropping any lands? (Number and size of parcels, list main crops)

¿Cultivas algunos terrenos a medias? (Número y tamaño de las parcelas, ¿qué cultivan ahí?)

Would you be willing to show me your maize stores?

¿Me mostrarías donde guardas tu maíz?

How much maize did you harvest last year?

¿Cuánto maíz cosecharon el año pasado?

How much did you sell?

¿Cuánto vendiste?

How much did you keep for seed?

¿Cuánto guardaste como semilla?

How much did you feed to the animals?

¿Cuánto del maíz fue para los animales?

How long did your maize last? Did it run out or did it get ruined by pests?

¿Cuánto duraba el maíz guardado? ¿Es que se acabó o es que se picó?

¿Does someone in the house sell handmade tortilla?

¿Es que alguien en la casa vende tortilla/tlayuda?

For tortillera in household:

How many days of the week do you sell tortilla?

¿Cuántas días de la semana vendes tortilla? 
How many days do you make tortilla for home consumption?

¿Cuántas días de la semana comen tortilla de la casa?

How often do you buy tortilla?

¿Con cuánta frecuencia compras tortilla?

\section{Questions Regarding Sharecropping Arrangements}

If sharecropper:

How do you and the landowners split the harvest?

¿Cómo dividen la cosecha tú y el dueño del terreno?

Who pays for what in the production process?

¿Quién paga los diferentes costos para llegar a la cosecha?

Is the contract fair?

¿Es justo el arreglo?

Where does the landowner live?

¿Dónde radica el dueño del terreno?

If landowner:

How do you and the sharecropper split the harvest?

¿Como dividen la cosecha tú y el mediero?

Who pays for what in the production process?

¿Quién paga los diferentes costos para llegar a la cosecha?

Is the contract fair?

¿Es justo el arreglo?

Questions Regarding Perception Local Climate Change

Has the climate changed much here in the past several decades?

¿Es que percibes un cambio de clima aquí en las últimas décadas?

(If yes) How has it changed?

¿Cómo ha cambiado?

What do you think has caused these change(s)?

¿Por qué razón o causa piensas que ha cambiado así? 
Appendix C: Land Tenure Arrangement Data 


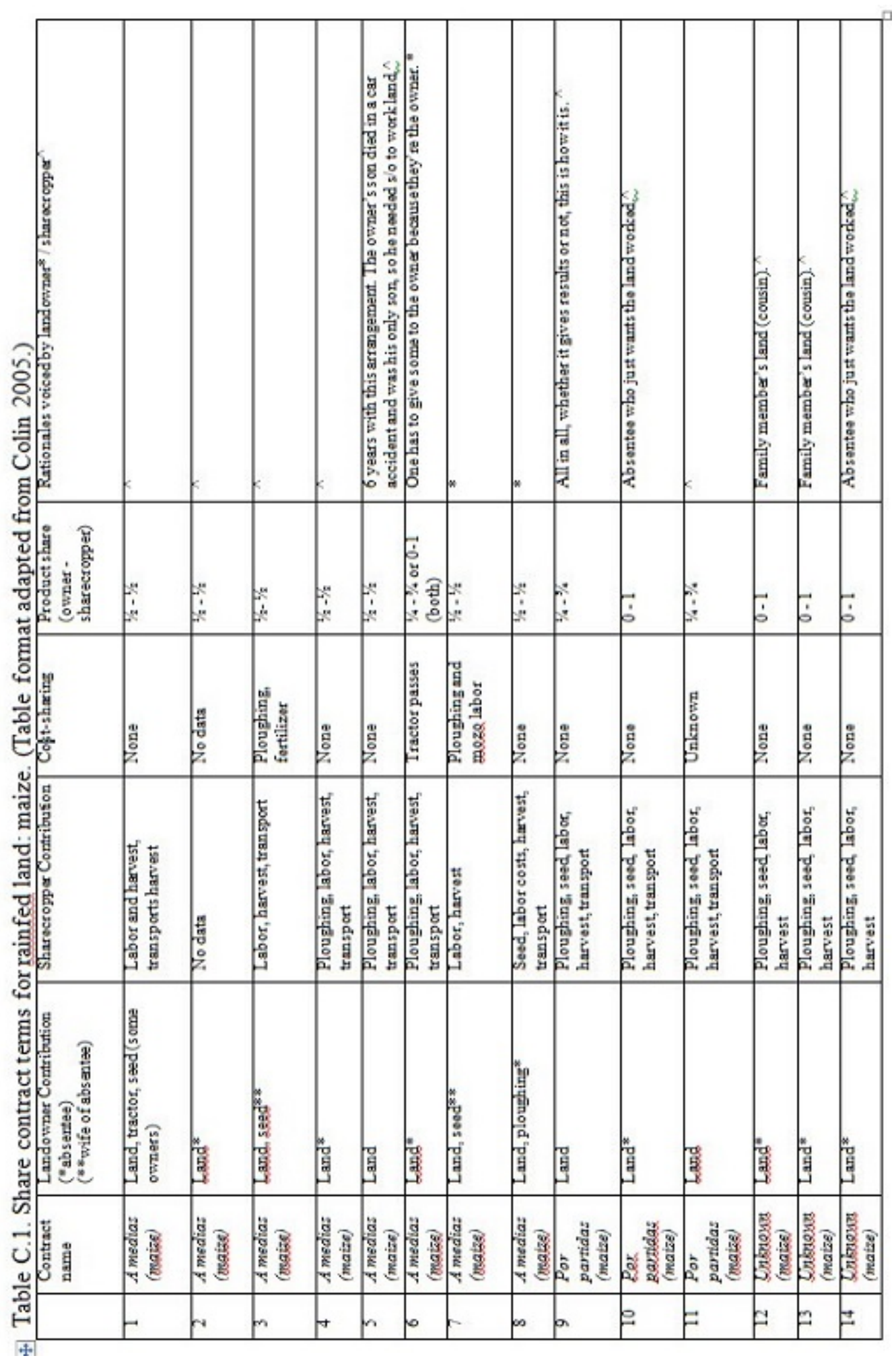




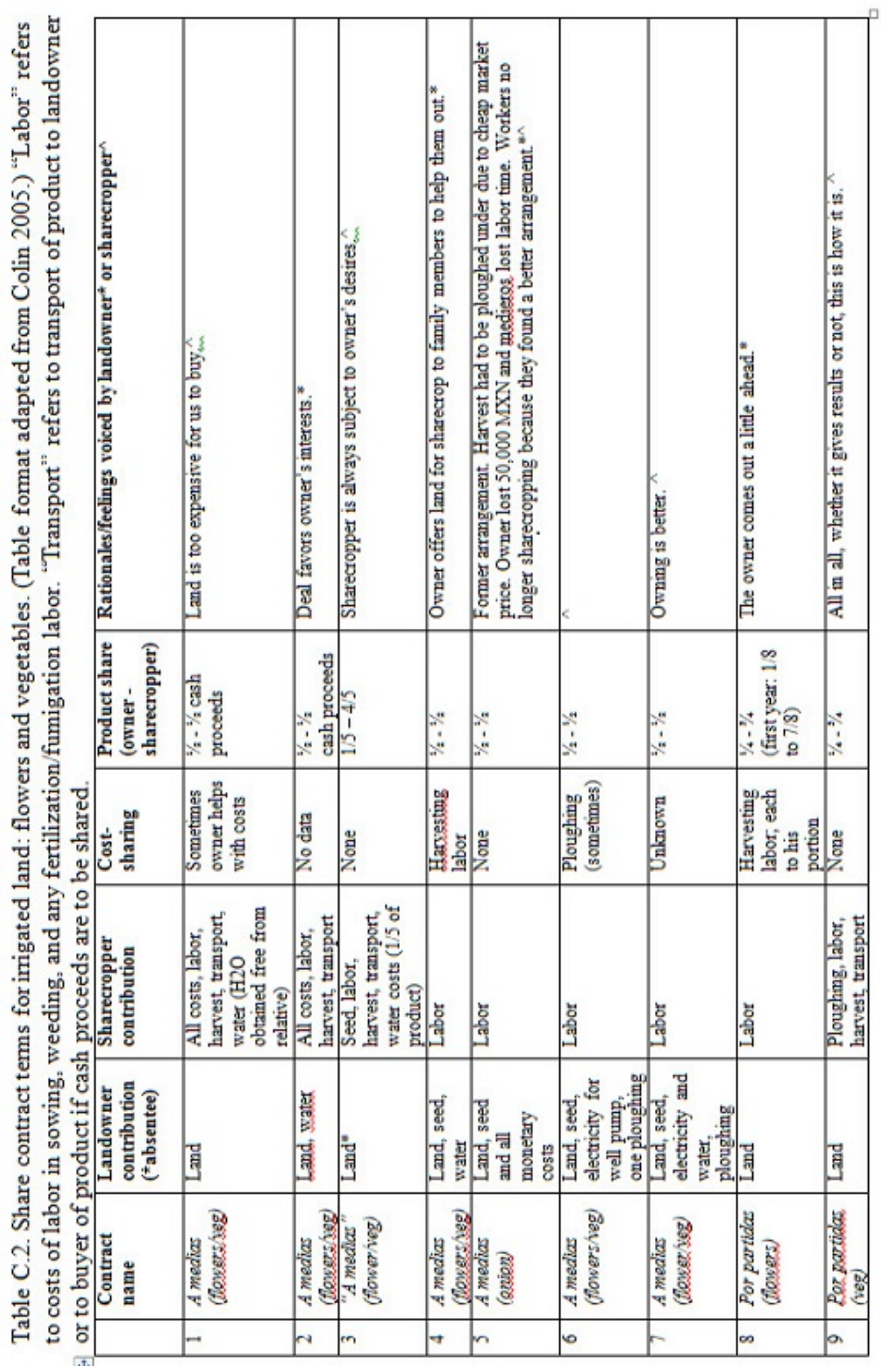

